\begin{tabular}{c}
$\frac{\text { ARTICLE }}{\text { CONSTITUTIONAL COLORBLINDNESS AND THE FAMILY }}$ \\
\hline \hline
\end{tabular}

\title{
KATIE EYER ${ }^{\dagger}$
}

Family law has escaped the colorblindness revolution. During the same time frame that the Supreme Court has adopted increasingly stringent constitutional standards for even "benign" uses of race (including, most notably, affirmative action), the lower courts have continued to take a loose and permissive approach to many government uses of race in the family law context. Thus, courts have continued to regularly affirm (and to apply minimal constitutional scrutiny to) the use of race to determine foster care and adoptive placements, as well as the use of race as a factor in custody disputes between interracial parents.

$\dagger$ Assistant Professor, Rutgers School of Law-Camden. Many thanks to Kerry Abrams, Susan Appleton, Jane Baron, Lee Carpenter, Ariela Dubler, Liz Emens, Bill Eskridge, Jean Galbraith, Sonya Garza, Ellen Goodman, Joanna Grossman, Jill Hasday, Stacy Hawkins, Kati Kovacs, Sophia Lee, Robin Lenhardt, Elizabeth MacDowell, Janice Madden, Earl Maltz, Serena Mayeri, Melissa Murray, Kim Mutcherson, Angela Onwuachi-Willig, Rick Swedloff, Alexander Tsesis, Gerardo Vildostegui, and Ingrid Waldron for their helpful feedback regarding this project. Serena Mayeri deserves particular thanks for helping me reconceptualize this project in its early stages. Earlier versions of this Article were presented at the 2013 Association of American Law Schools (AALS) Annual Meeting, the University of Pennsylvania Gender and Sexuality Works in Progress (GASWorks) seminar series, the 2011 Law and Society Association (LSA) Annual Meeting, the 2012 Emerging Family Law Teachers and Scholars Conference, the 2012 Midatlantic Law \& Society Meeting, the Rutgers Junior Faculty Colloquium, the Loyola University Chicago School of Law Third Annual Constitutional Law Colloquium, the Vanderbilt Law School Faculty Workshop, the Villanova Law School Faculty Colloquium and the Washington University School of Law Faculty Workshop Series; this Article benefitted greatly from feedback received from participants. Yuri Fuchs, Harper Seldin, Tian Wen, and other members of the editorial staff of the University of Pennsylvania Law Review provided excellent editorial feedback. Al Dong at the University of Pennsylvania, John Jacob at Washington and Lee University, and the research librarians at the Library of Congress provided excellent assistance in accessing difficult-to-locate or archival materials. Special thanks to the Alice Paul Center for Research on Women, Gender and Sexuality for supporting my work during the early stages of this project. This Article received Honorable Mention in the 2013 AALS Scholarly Papers Competition. 
This Article, drawing on heretofore unexplored historical sources, examines the Supreme Court's role in the development of these divergent approaches to the use of race in the affirmative action and family law contexts. As those sources demonstrate, the Court has-over the last forty years - had numerous opportunities to address the growing divide. Nevertheless, the Court (and particularly some of its most ardent affirmative action detractors) has historically been reluctant to do so, at least in part because of a normative endorsement of the race-based practices at issue in the family law context. Thus, the Court has avoided cases involving the use of race in family law-and taken other steps to limit the reach of its doctrine in the family law arena-based on a perception that remaining uses of race in the family are fundamentally different, and at least in some contexts, benign.

This history has profound implications for the Court's broader race law jurisprudence. The Supreme Court has-at least facially-rejected the possibility of a role for contextual or normative factors in its application of equal protection doctrine to race. Instead, the Court has demanded that race-based classificationsno matter what their intent or effects-be subjected to strict scrutiny. But the history of the Court's approach to family law strongly suggests that the Court itself does in fact weigh such considerations in its approach to taking up and adjudicating race law claims. This Article suggests that there are serious process, legitimacy, and substantive concerns raised by such a divergence between the Court's formal doctrine and its practice, and discusses alternatives for aligning the two more fully.

INTRODUCTION 538

I. RACE IN THE FAMILY FROM LOVING TO

DRUMMOND: 1967-1978 546

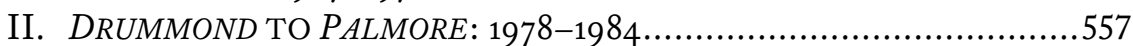

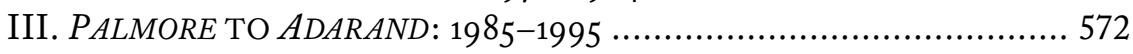

IV. ADARAND TO GAMBLA: 1996-2007 …..................................... 579

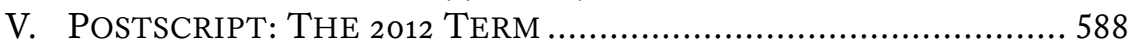

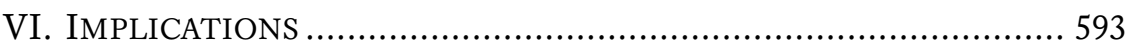

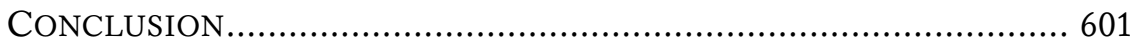

\section{INTRODUCTION}

By all accounts, the colorblindness revolution has arrived. Since City of Richmond v. J.A. Croson Co., ${ }^{1}$ Supreme Court majorities have proclaimed the Court's obligation to subject all uses of race to the "most rigid scrutiny."

1488 U.S. 469 (1989).

2 Adarand Constructors, Inc. v. Pena, 515 U.S. 200, 236 (1995) (quoting Korematsu v. United States, 323 U.S. 214, 216 (1944)); see also Fisher v. Univ. of Tex. at Austin, 133 S. Ct. 2411, 2419 
Thus, the Court's ostensible command has been that even programs intended to benefit minority group members-such as affirmative action-must be subjected to the same constitutional regime as undoubtedly invidious uses of race. Undergirding this approach have been empirical and moral claims of the necessity of consistency in treating all uses of race as inherently suspect. $^{3}$ Scholars have reinforced this account, contending that the Supreme Court has fundamentally turned away from a contextually variable approach to race to one in which all uses of race are treated as presumptively malign. ${ }^{4}$

But the colorblindness revolution's reported rise has been at least partially apocryphal. Contrary to conventional wisdom, the courts do not strictly scrutinize all government uses of race. Indeed, colorblindness doctrine has-despite its sweeping rhetoric-failed to reach a wide array of racial domains. ${ }^{5}$ As a result, many putatively benign government uses of

(2013); Gratz v. Bollinger, 539 U.S. 244, 270 (2003); Croson, 488 U.S. 469, 493-95 (1989) (plurality opinion); id., 488 U.S. at 520 (Scalia, J., concurring).

3 See, e.g., Fisher, 133 S. Ct. at 2418; id., 133 S. Ct. at 2422 (Thomas, J., concurring); Parents Involved in Cmty. Sch. v. Seattle Sch. Dist. No. 1 (PICS), 551 U.S. 701, 721, 745-48 (2007); id., 551 U.S. at 751-52, 758, 778-82 (Thomas, J., concurring); Adarand, 515 U.S. at 223-24, 229, 236; id., 515 U.S. at 240-41 (Thomas, J., concurring); Shaw v. Reno, 509 U.S. 630, 643 (1993); Croson, 488 U.S. at $493-94 ;$ id., 488 U.S. at 521, 527-28 (Scalia, J., concurring).

4 See, e.g., Ian F. Haney López, “A Nation of Minorities”: Race, Ethnicity, and Reactionary Colorblindness, 59 StAn. L. REv. 985, 985 (2007); Reginald Oh, Discrimination and Distrust: A Critical Linguistic Analysis of the Discrimination Concept, 7 U. PA. J. CONST. L. 837, 861 (2005); see also Ariela J. Gross, From the Streets to the Courts: Doing Grassroots Legal History of the Civil Rights Era, 90 TEX. L. ReV. 1233, 1250-51 (2012) (reviewing TOMIKO BROWN-NAGIN, COURAGE TO Dissent: Atlanta and the Long History of the Civil Rights Movement (2010)). But cf. Jack M. Balkin \& Reva B. Siegel, The American Civil Rights Tradition: Anticlassification or Antisubordination, 58 U. MIAMI L. REV. 9, 25-28 (2003) (arguing that, in reality, assessments of what will count as a "classification" in equal protection doctrine are informed by other widely shared normative values); R. Richard Banks, The Benign-Invidious Asymmetry in Equal Protection Analysis, 31 HASTINGS CONST. L.Q. 573, 574-75 (2003) (arguing that "[e]ven seemingly stalwart defenders of a symmetrical nondiscrimination mandate may, in practice, support the very sort of asymmetry they purport to oppose").

5 The acontextual colorblindness doctrine developed in the Court's affirmative action cases has been extended only to a limited number of contexts outside of affirmative action, most notably to race-based primary school assignments and to race-based redistricting. See PICS, 551 U.S. at 720; Miller v. Johnson, 515 U.S. 900, 904-05 (1995). But cf. infra note 289 and accompanying text (noting that the Court has not always applied the same gatekeeping standards even in those contexts to which it has purportedly extended its affirmative action precedents). There are many other areas to which colorblindness doctrine has not been extended robustly, including family law, non-racially classifying but race-intentional government programs, recordkeeping, race-based suspect selection, and others. See Balkin \& Siegel, supra note 4, at 16-18 (describing other contexts in which the courts have declined to extend strict scrutiny, including the census and race-based suspect descriptions); Jack M. Balkin \& Reva B. Siegel, Principles, Practices, and Social Movements, 154 U. PA. L. REV. 927, 939-940 (2006) [hereinafter Balkin \& Siegel, Principles] (listing racial data collection and recordkeeping); Banks, supra note 4, at 579 (noting that lower courts have declined to apply strict scrutiny to race-intentional but not racially classifying government actions); $\mathrm{R}$. 
race have continued to be ubiquitous - and largely constitutionally unchallenged-long past the announcement of the Court's stringent and ostensibly global approach to contemporary uses of race. And, while the partialness of the colorblindness revolution is perhaps most vividly apparent in the lower courts, it has been far from restricted to that context. Thus, the Supreme Court itself has-through docket management and more direct meansdeclined to fully embrace the implications of its colorblindness revolution. ${ }^{6}$

This Article tells the story of one of the most persistent and striking contexts in which the "colorblindness revolution" has been more illusory than real: the use of race in family law. ${ }^{7}$ Beginning with the aftermath of Loving $v$. Virginia, ${ }^{8}$ a decision often canonized as the endpoint of race-based family law rules, ${ }^{9}$ it traces the courts' generally permissive response to remaining official uses of race in the family during the following half

Richard Banks, Race-Based Suspect Selection and Colorblind Equal Protection Doctrine and Discourse, 48 UCLA L. REV. 1075 (2001) [hereinafter Banks, Race-Based Suspect Selection] (providing an extended treatment of race-based suspect selection); R. Richard Banks, The Color of Desire: Fulfilling Adoptive Parents' Racial Preferences Through Discriminatory State Action, 107 YALE L.J. 875, 904-08 (1998) [hereinafter Banks, Color of Desire] (same, listing legislative districting, criminal profiles, adoption, and recordkeeping); R. Richard Banks, The Illusion of Colorblindness in Antidiscrimination Law (unpublished manuscript) (on file with author) [hereinafter Banks, Colorblindness] (listing race-based suspect profiles, facilitative accommodation in adoption, and racial casting); infra Parts I-V (detailing the courts' constitutionally permissive approach to contemporary uses of race in family law).

6 Supra note 5; see also Monroe v. City of Charlottesville, 579 F.3d 380 (4th Cir. 2009), cert. denied, $130 \mathrm{~S}$. Ct. 1740 (2010) (denying certiorari in a case exempting race-based suspect selection from equal protection scrutiny); Brown v. City of Oneanta, 221 F.3d 329 (2d Cir. 2000), cert. denied, 534 U.S. 816 (2001) (same).

7 In the interest of space, there is one major omission from my discussion of this subject. Specifically, with the exception of the case of Adoptive Couple v. Baby Girl, 133 S. Ct. $255^{2}$ (2013), I have not taken up the distinct constitutional issues presented by the use of race or heritage in family law determinations involving Native American children, or the statutory scheme that governs such uses, the Indian Child Welfare Act (ICWA). The constitutional issues presented in this context are analytically distinct in light of the Court's historic treatment of classifications based on Indian status as political, rather than racial. See Morton v. Mancari, 417 U.S. 535, 552-53 (1973). Thus, while there are both political and legal interrelationships between the historical approach to custody and adoptive placement of Native American children and the approach taken vis-à-vis other minority children, a full discussion of this issue exceeds the scope of this Article. See RANDALL KENNEDY, INTERRACIAL INTIMACIES 480-518 (2003) (addressing this issue separately for similar reasons).

Leaving aside the Native American context, the majority of the discourse and practice around the contemporary use of race in the family law context has focused on black or black-biracial children. Thus, while I do not exclude from my discussion cases dealing with other minority children (or, on rare occasions, Caucasian children), my discussion is most salient to and typified by agency and judicial practice vis-à-vis black and black-biracial children.

8388 U.S. 1 (1967).

9 Mark Rahdert, Transracial Adoption-A Constitutional Perspective, 68 TEMP. L. REV. 1687, 1690 (1995). 
century. As this exploration reveals, the use of race in the family has remained robust in the post-Loving era, with many state agencies and courts continuing to apply race-based rules in the adoption, foster care, and custody contexts. ${ }^{10}$ Constitutional challenges to these race-based actions have generally fared poorly, with courts typically (albeit not always) applying de minimis constitutional scrutiny. Thus, during the same time frame that the Supreme Court has increasingly proclaimed the need to strictly scrutinize all government uses of race, family law has remained a bastion of racial permissiveness.

This divergence has-unsurprisingly-not gone unremarked in the legal literature. Indeed, a number of scholars have argued for the erroneousness of the lower courts' approach to contemporary uses of race in family law (or the unconstitutionality of such racial policies themselves), contending that the Court's contemporary affirmative action jurisprudence demands the application of strict scrutiny, and that this high bar is one that contemporary uses of race in the family are unable to meet. ${ }^{11}$ According to these scholars, the lower courts' approach to the use of race in the family has fundamentally diverged from the Supreme Court's race law jurisprudence and should be brought in line with contemporary affirmative action jurisprudence. Thus, the story that has been told by contemporary scholars is primarily one of lower court disobedience-one in which the lower courts have failed to act as faithful implementers of the Supreme Court's colorblindness revolution-and not one which calls into question the dominant narrative of the Court's own jurisprudence.

But there is a profoundly different story to be told regarding the contemporary history of race in family law. As archival Supreme Court documents reveal, far from diverging from the Supreme Court's intended approach to the use of race in family law, it appears that the Court itself-and particularly

10 While Palmore v. Sidoti, 466 U.S. 429, 434 (1984), struck down one particular use of race in child custody in the mid-1980s (i.e., the practice of removing custody based on a parent's interracial marriage), it did little to disrupt continuing uses of race outside of that specific context, including uses of race in adoption, foster care, and interracial parent custody disputes. See infra Parts II-III.

11 See, e.g., Elizabeth Bartholet, Where Do Black Children Belong? The Politics of Race Matching in Adoption, 139 U. PA. L. REv. 1163 (1991); David Meyer, Lecture, Palmore Comes of Age: The Place of Race in the Placement of Children, 18 U. FLA. J.L. \& PUB. POL'Y 183, 185-87 (2007); Davidson Pattiz, Racial Preference in Adoption: An Equal Protection Challenge, 82 GEO. L.J. 2571 (1994); David Rottenstein, Trans-Racial Adoption and the Statutory Preference Schemes: Before the "Best Interests" and After the "Melting Pot," 68 ST. JOHN's L. REV. 137 (1994). For a divergent perspective, see Twila L. Perry, The Transracial Adoption Controversy: An Analysis of Discourse and Subordination, 21 N.Y.U. REV. L. \& SOC. CHANGE 33 (1993-1994). 
its race conservatives ${ }^{12}$ - have deliberately shielded continued uses of race in the family law context from rigorous constitutional scrutiny. Thus, although the Court in Palmore v. Sidoti did take up one contemporary instantiation of the use of race in family law (the practice of depriving a parent of custody based on a post-divorce interracial marriage), it acted carefully in crafting its opinion to ensure that it would not inhibit other continuing uses of race in the family (including especially adoption)..$^{13}$ And when the lower courts, in response, read Palmore narrowly and continued to decline to apply strict scrutiny review, the Court repeatedly declined invitations to revisit the balance struck in Palmore, based at least in part on the Court's race conservatives' perception that the remaining uses of race in family law were simply "different" and, at least in some circumstances, "benign." ${ }^{14}$

Nor was the tension between the Court's affirmative action jurisprudence and the lower courts' permissive approach to race in family law simply lost on the Justices during this time. Since the very beginning of the Court's modern foray into the affirmative action context, parallels between affirmative action and contemporary uses of race in the family law context-

12 This Article uses the terms "race conservatives," "race moderates," and "race liberals" as a shorthand for the array of positions that have been taken by the Justices in the affirmative action context vis-à-vis the appropriateness of considering contextual factors (such as whether a particular use of race is "benign") in determining whether strict scrutiny applies. Although there are other axes on which one might divide the Justices into categories, for the purposes of this Article, endorsement of full strict scrutiny review (without consideration of normative or other contextual factors) was selected as the most pertinent divide. Thus, Justices who, during the historical time period at issue, clearly expressed (internally or externally) the view that full strict scrutiny should be applied even to putatively benign uses of race, such as affirmative action, are characterized as "race conservatives." Those who expressed the view that a more flexible or relaxed regime should apply are characterized as "race liberals." And those who were either inconsistent (at that time) or who were ambiguous as to their position are characterized as "race moderates." I borrow this helpful trichotomy (with a number of modifications) from Reva Siegel's work but recognize that these shorthand terms may oversimplify the range of positions that the Justices have taken vis-à-vis these issues over time. See Reva B. Siegel, From Colorblindness to Antibalkanization: An Emerging Ground of Decision in Race Equality Cases, 120 YALE L.J. 1278, 1282 (2011) [hereinafter Siegel, Antibalkanization].

13 See infra Part II.

14 See infra Parts III-IV. The Court has declined to take up challenges to race-based family law practices in a number of cases. See, e.g., J.H.H. v. O'Hara, 878 F.2d 240 (8th Cir. 1989), cert. denied, 493 U.S. 1072 (1990); Gambla v. Gambla, 853 N.E.2d 847 (Ill. Ct. App. 2006), cert. denied, $55^{2}$ U.S. 810 (2007); Wilson v. Darrow (Ky. Ct. App. 1989), cert. denied, 498 U.S. 851 (1990); In re Adoption/Guardianship No. 2633, 646 A.2d 1036 (Md. Ct. Spec. App. 1994), cert. denied, 516 U.S. 809 (1995); In re Welfare of D.L., 486 N.W.2d 375 (Minn. 1992), cert. denied, 506 U.S. 1000 (1992); Carlson v. County of Hennepin, 428 N.W.2d 453 (Minn. Ct. App. 1988), cert. denied, 490 U.S. 1023 (1989); see also Memorandum from J.B., Law Clerk, on No. 90-123-CX, Wilson v. Darrow, to the Cert Pool 3-4 (Aug. 10, 1990) (on file with Lee Epstein, Jeffrey A. Segal \& Harold J. Spaeth, The Digitial Archive of the Papers of Justice Harry A. Blackmun (2007), http://epstein.usc.edu/ research/BlackmunArchive.html [hereinafter Blackmun Digital Archive]). 
their characterization as benign, their putative benefits for minority ${ }^{15}$ group members-were repeatedly called to the Court's attention. Thus, both litigants and the Justices' own law clerks have repeatedly highlighted for the Justices the doctrinal and logical overlaps between race-based family law adjudication and affirmative action jurisprudence. And, indeed, even where others have not explicitly pointed out such overlaps, the Justices themselves have done so sua sponte, identifying doctrinal overlaps between affirmative action and family law in their internal communications.

Unearthing this rich history has a number of important implications. ${ }^{16}$ Most significantly, exploring the constitutional history of race-based family law rules at the Supreme Court level exposes the ways in which the Court has-sub rosa-profoundly diverged from its claimed colorblindness project. Thus, the Court has claimed to reject the possibility that particular uses of race might be exempted from stringent constitutional scrutiny-on the reasoning that uses of race by the government are inherently malignwhile simultaneously taking a deferential approach to other (non-affirmative action) uses of race. ${ }^{17}$ Indeed, it appears that certain family law uses of raceincluding particularly race-matching in adoption-have been deliberately shielded from strict scrutiny based on the perception that they are fundamentally "different" and-unlike affirmative action-potentially benign. Thus, while the Court has facially claimed to adhere to a rule rejecting the

15 Most (but not all) of the cases described herein arose in the context of family law decisionmaking vis-à-vis black or black-biracial children. See supra note 7 . Thus, although I use the global term "minority" to include the limited case law that has arisen outside of that context (and outside of the Native American context, omitted from full discussion herein), the majority of cases described herein involved black or black-biracial children, a factor that may have been salient to the courts' decisionmaking. Cf. infra note 260 (discussing the historical tendency to essentialize individuals with relatively minimal Native American heritage as white, while essentializing those with any African American heritage as black).

16 One important implication, which I do not discuss here, is that this history further substantiates the robust scholarly consensus that family law is often treated as "exceptional," and thus not subject to normal doctrinal rules, by the courts. See, e.g., JiLl ElAine HASDAY, FAmilY LAW REIMAGINED: RECASTING THE CANON (forthcoming 2014) (manuscript at 3) (on file with author) (describing family law exceptionalism as the "premise that family law rejects what the law otherwise does, and does what the law otherwise rejects"). See generally Janet Halley \& Kerry Rittich, Critical Directions in Comparative Family Law: Genealogies and Contemporary Studies of Family Law Exceptionalism, 58 AM. J. COMP. L. 753 (2010) (introduction to a special journal issue dedicated to Family Law Exceptionalism). Indeed, it appears that civil rights is a robust area for family law exceptionalism, with civil rights doctrines often being disregarded-or only partially incorporated-in the family law context. This Article is a part of a broader project investigating the manifestations and causes of family law exceptionalism in the civil rights context, other portions of which aim to more fully situate civil rights family law exceptionalism within the broader family law exceptionalism literature.

17 See infra Part VI. 
salience of contextual factors in determining the level of constitutional scrutiny to be applied, it has, in practice, looked precisely to such factors as a basis for exempting particular uses of race from rigorous constitutional review.

This discordance between the Court's articulated standard for constitutional race adjudication and its actual approach raises profound concerns. Among other things, by formally denying the salience of racial classifications' contextual underpinnings (while attending to them sub rosa), the Court has deprived litigants of the opportunity to influence its choice of how contextual factors matter, and thus to influence its ultimate determination of whether and where to rigorously enforce stringent standards of constitutional review. Moreover, such an undercover approach-by necessity unguided by fixed legal standards-must necessarily rest on precisely the type of intuitive, instinctive judgments about race (and about which uses of race have value) that troublingly echo America's recent constitutional past. Finally, the Court's formal adoption of a rule that does not accurately reflect its true decisionmaking criteria can only lead to distortions in its substantive doctrine, insofar as the Court will find it increasingly difficult to avoid the more radical implications of its own pronouncements.

The modern history of race in family law thus calls for a reevaluation of the absence of an explicit place for contextual and normative considerations in contemporary race law jurisprudence. ${ }^{18}$ If, indeed, the Court is engaging sub silentio in the practice of shielding certain racial practices from rigorous constitutional scrutiny based on context-specific concerns, there are strong reasons why the process by which the Court does so should be unobscured and made a part of the formal framework of equal protection doctrine. ${ }^{19}$ While it is not clear that such formal recognition of contextual variability would result in a reversal of the Court's affirmative action doctrine at this juncture (and, indeed, the Court might well adhere to its view that all affirmative action programs must uniformly be strictly scrutinized), the benefits of such doctrinal "truth in advertising" would nevertheless (for all the reasons adverted to above) be profound. Thus, the history of race in family law strongly suggests that the time has come to reconsider the Court's decades-old rejection of the notion that normative and contextual considerations matter to race law adjudication.

18 Cf. Banks, supra note 4, at 574 (discussing the formal absence of a "Benign-Invidious Asymmetry" in equal protection doctrine and suggesting that courts in fact deploy common sense intuitions about what uses of race are benign, despite their formal rejection of such an approach).

19 See infra Part VI. 
This Article takes up the foregoing issues as follows: Part I (1967-1978) traces the constitutional treatment of race-based family law practices during the immediate post-Loving era and explores the initial emergence of a divide in the Court's approach to uses of race in the affirmative action and family law contexts. Part II (1979-1984) turns to a discussion of Palmore v. Sidoti and the substantial internal debates that Palmore prompted (despite its ultimate unanimity) regarding remaining instantiations of race in family law. This Part shows that Palmore was controversial in part precisely because of its potential implications for other contemporary uses of race in family law (including particularly race-matching in adoption) and the desire of a number of the Justices to leave race-matching in adoption undisturbed.

Part III (1985-1995) explores the very profound divergence that occurred in the post-Palmore period between the Court's affirmative action jurisprudence (where the Court increasingly demanded that all uses of race be strictly scrutinized) and the lower courts' approach to race in family law (where the courts most often declined to apply any meaningful constitutional scrutiny to continuing uses of race). This Part further traces these lower court family law decisions to the petition for certiorari stage, where they were repeatedly rejected by the Court, even where the affirmative actionfamily law divide was squarely raised. Part IV (1996-2007) continues to follow this divergence through the contemporary era and discusses the Court's continued failure to address even the most clear divergences from its ostensible demand of strict scrutiny in the family law context. Part V, in Epilogue, takes up the recently decided case of Adoptive Couple v. Baby Girl and addresses the Court's continued failure-nearly half a century after Loving - to meaningfully address the affirmative action-family law divide.

Part VI turns at last to the implications of this rich history for the Court's race law jurisprudence. Drawing together the historical materials explored in Parts I-V, this Part discusses the ways in which the Court's publicly articulated rhetoric (rejecting the possibility of lesser constitutional scrutiny for particular uses of race) has failed to reflect its internal actions (facilitating precisely such a regime in the family law arena). Part VI then discusses the profound concerns this divergence raises, including the legitimacy and process defects it creates. Finally, this Part explores potential ways that the Court's race law doctrine might be rendered consistent with its practices, including the reintroduction in the Court's formal equal protection doctrine of a place for contextually and normatively based variations in the applicable standard of review. 


\section{RACE IN THE FAMILY FROM LOVING TO DRUMMOND: 1967-1978}

The years following the Supreme Court's 1967 decision in Loving v. Virginia marked the high point for the constitutional invalidation of race-based decisionmaking in family law. During the five years following Loving, eight lower courts, many within the Deep South, invalidated race-based family law restrictions on Fourteenth Amendment grounds. ${ }^{20}$ And while many of these cases can be characterized as tying up the loose ends of Lovinginvalidating antimiscegenation laws in response to the intransigence of local officials-others reached more broadly, constitutionally invalidating statutory restrictions on transracial adoption and relying on Loving to open up inheritance rights to the relatives of interracial couples. Thus, the five-year period between 1967 and 1972 can fairly be characterized as the most activist time frame in history for the courts' adjudication of constitutional racebased family law claims.

By the mid-1970s, however, this unified approach had begun to dissolve in the face of broader political and legal developments. Politically, the late 1960 s and early 1970 s witnessed a major transformation in the discourse around race equality as the black power and cultural nationalism movements gained national prominence. ${ }^{21}$ These movements, which called for the celebration and preservation of black difference (and often directly for racial separatism), meant that for the first time minority voices became prominent

20 See Compos v. McKeithen, 341 F. Supp. 264 (E.D. La. 1972) (striking down ban on interracial adoption as a violation of equal protection); United States v. Brittain, 319 F. Supp. 1058 (N.D. Ala. 1970) (overturning Alabama miscegenation bans); Davis v. Ashford, 2 Race Rel. L. Surv. 152 (S.D. Miss. 1970) (invalidating a Mississippi statute banning miscegenation); Davis v. Gately, 269 F. Supp. 996 (D. Del. 1967) (invalidating Delaware's criminal and civil antimiscegenation statutes); Van Hook v. Blanton, 206 So. 2d 210 (Fla. 1968) (per curiam) (declaring Florida's antimiscegenation laws invalid); Hibbert v. Mudd, 272 So. 2 d 697 (La. Ct. App. 1972) (noting that the lower court had relied on Loving to invalidate a law that banned miscegenous heirs from receiving their inheritance), rev'd on other grounds, 294 So. 2d 518 (La. 1974); Dick v. Reaves, 434 P.2d 295 (Okla. 1967) (in the context of an inheritance dispute, invalidating Oklahoma's antimiscegenation law); In re Adoption of Gomez, 424 S.W.2d 656 (Tex. Civ. App. 1967) (per curiam) (finding ban on interracial adoption to be unconstitutional). But cf. Vetrano v. Gardner, $290 \mathrm{~F}$. Supp. 200 (N.D. Miss. 1968) (denying social security benefits to children of an interracial couple because their parents were unmarried, and rejecting a constitutional challenge to same despite the fact that interracial marriage was unlawful in the jurisdiction in which the parents lived during the relevant time frame). In contrast, during the five-year period preceding Loving, not a single lower court invalidated a race-based family law policy on constitutional grounds.

21 See generally Lloren A. Foster, Black Power Movement, in ENCYClOPEDIA OF AFRICAN AMERICAN HISTORY: 1896 TO THE PRESENT (Paul Finkelman ed., 2006); THOMAS J. Sugrue, SweEt Land of Liberty: THe ForgotTen Struggle For Civil Rights in THE NORTH (2008); Lisa Corrigan, Reimagining Black Power: Prison Manifestos and the Strategies of Regeneration in the Rewriting of Black Identity, 1969-2002 (2006) (unpublished Ph.D. dissertation, University of Maryland) (on file with author). 
in promoting race's salience in family law decisionmaking. ${ }^{22}$ Indeed, by the early to mid-1970s, the most vocal advocates of official restrictions on interracial family formation tended to be minority organizations, such as the National Association of Black Social Workers (NABSW). ${ }^{23}$ Noting the unique needs of minority children, such organizations argued strongly against interracial adoptive and foster care placements, contending that nonminority parents were not competent to instill a healthy sense of racial identity in black or biracial children. ${ }^{24}$

Legally, the early 1970 also witnessed major transformations in the form of racial restrictions in family law. By 1973, most Jim Crow-era statutes categorically precluding interracial intimacy and family formation had been struck down or repealed. ${ }^{25}$ The policies that remained-many of which were

22 See supra note 21 and infra note 24; cf. Susan J. Grossman, $A$ Child of a Different Color: Race as a Factor in Adoption and Custody Proceedings, 17 BUFF. L. REV. 303, 331-32 (1967-1968) (describing then-existing arguments for race-matching in custody and adoption law, which derived predominantly from traditional adoption practices promoting the appearance of a "natural" family and from Jim Crow-era disapproval of race mixing). For an early decision that was particularly explicit in drawing on black power political concepts, see In re B. Children, 89 Misc. 2d 493 (N.Y. Fam. Ct. 1977) (finding that a black child was "entitled to his 'Black Pride"" and thus should be returned to the home of his biological parents rather than remaining with his white foster parents).

23 KENNEDY, supra note 7, at 111-12, 393-98; Bartholet, supra note 11, at 1179-82. During this same time frame, Indian organizations, such as the Association on Indian Affairs, were also increasingly agitating for restrictions on the placement of Indian children with non-Indian families. See, e.g., Thalia Gonzalez, Reclaiming the Promise of the Indian Child Welfare Act: A Study of State Incorporation and Adoption of Legal Protections for Indian Status Offenders, 42 N.M. L. REV. 131, 139-40 (2012) (chronicling the advocacy leading to the enactment of the ICWA); see also Maria E. Camposeco, Bright Hopes, Shared Heritage: Helping Latino Kids Find Roots when Adopted, SACRAMENTO BEE, July 8, 1992, at B1 (noting the decades-long opposition of both the NABSW and the Indian community to placing black or Indian children with white families). These efforts ultimately culminated in the successful enactment of the ICWA, a federal statute that requires the placement of Indian children in Indian homes in many circumstances. 25 U.S.C. $\$ \S 1901-23$ (2006); see also Gonzalez, supra, at 140-41 (describing the protections afforded by the ICWA). The ICWA has, in turn, provided a template for calls for similar legislation vis-à-vis African American and other minority children. See, e.g., Jessica Dixon, The African-American Child Welfare Act: A Legal Redress for African-American Disproportionality in Child Protection Cases, 10 BERKELEY J. AFR.AM. L. \& POL'Y 109, 112-113, 125-126 (2008) (arguing for an "African-American Child Welfare Act" modeled on the ICWA).

24 See, e.g., KENNEDY, supra note 7, at 393-98; Bartholet, supra note 11, at 1179-82 (discussing the opposition by NABSW and others to transracial adoption in the early 1970s). These sentiments would eventually come to be significantly reflected in the case law. For an interesting and nuanced treatment of the issues that spurred the development of NABSW's position in this area, see generally Laura Briggs, Somebody's Children, 2009 UTAH L. REV. 421 (2009).

25 In addition to the antimiscegenation laws that were invalidated by Loving, many states had child-focused criminal or civil restrictions on interracial families during the Jim Crow era. See, e.g., LA. REV. STAT. ANN. § 9:422 (1965) (prohibiting interracial adoptions); MD. CODE ANN., CRIMES \& PUNISHMENTS $\S 416$ (LexisNexis 1957) (making it a criminal offense for a white 
informal or administrative in nature-were less likely to be codified, and, at least in theory, less categorical, considering race as only "a factor" among many. ${ }^{26}$ While formal and more categorical statutes and administrative policies would later experience a resurgence, during the mid-197os the predominant uses of race in family law tended facially to be more flexible and were typically justified as part of a global consideration of the child's best interests. ${ }^{27}$

Collectively, these changes in the political and legal context had a major impact on judicial perceptions of the legitimacy of race restrictions in family law. During the late 1960s and early 1970s, family law race restrictions had been fairly uniformly identified by the courts as vestiges of the nation's Jim Crow past. ${ }^{28}$ But by the mid-197os, this confluence of political and legal changes had considerably complicated the characterization of race-based family law decisionmaking as a form of invidious race discrimination. Like affirmative action, the presence of minority advocates for race-based family law policies - and the arguable deployment of such policies in service of a "benign" goal (i.e., the best interest of the child) rendered the constitutional assessment of racial family law policies far from unambiguous. ${ }^{29}$ Thus, as the dominant discourse behind race-based family law restrictions shifted,

woman to conceive and bear an interracial child); S.C. CODE ANN. § 10-2585 (1962) (prohibiting interracial children from being adopted by anyone); $i d$. $\S 16-553$ (making it a criminal offense to place a white child in "the custody, control, maintenance or support of a negro"); TEX. REV. CIV. STAT. ANN., arts. 46a $\S(8), 46 \mathrm{~b}-1 \S(4)$ (1959) (prohibiting interracial adoptions). It appears that, by the early 1970s, the most blatantly racist of these laws had been struck down or repealed or had fallen into disuse, although many statutes requiring the consideration of race in adoption remained. See, e.g., Compos, 341 F. Supp. at 264-68 (invalidating Louisiana's law banning interracial adoption); In re Gomez, 424 S.W.2d at 657-59 (invalidating Texas law banning interracial adoption); see also Grossman, supra note 22, at 306-09 (noting that, as of 1968, Louisiana and Texas were the only states that categorically prohibited interracial adoption, although many others required consideration of race).

26 Of the race family law cases arising during the five-year period from 1973 through 1977, none involved a statutory or regulatory policy requiring race-matching. Instead, most involved informal judicial or administrative policies sanctioning race only as a factor in the best interest analysis. See, e.g., Drummond v. Fulton Cnty. Dep't of Family \& Children's Servs., 563 F.2d 1200, 1204-05 (5th Cir. 1977) (en banc), cert. denied, 437 U.S. 910 (1978); White v. Appleton, 304 So. $2 \mathrm{~d}$ 206 (Ala. Civ. App. 1974); Niles v. Niles, 299 So.2d 162 (Fla. Dist. Ct. App. 1974); Raysor v. Gabbey, 395 N.Y.S.2d 290 (App. Div. 1977). But cf. Beazley v. Davis, 545 P.2d 206, 207-08 (Nev. 1976) (finding that the lower court's use of an apparently categorical approach to match children of an interracial marriage with their minority parent was unconstitutional).

27 See Cynthia G. Hawkins-León \& Carla Bradley, Race and Transracial Adoption: The Answer Is Neither Simply Black or White nor Right or Wrong, $5^{1}$ CATH. U. L. REV. 1227, 1241 (2002) (stating that, as of 1987 , "35 states prohibited the adoption of black children by white families").

28 See supra note 20.

29 See supra note 26; see also In re B. Children, 89 Misc. 2d 493, 495-98 (N.Y. Fam. Ct. 1977) (treating reliance on race as valid based in part on its benign objectives). 
the judicial treatment of race restrictions in family law also changed direction, from near-universal rejection in the immediate post-Loving period to a state of profound division. ${ }^{30}$

Mildred and Robert Drummond, a white couple from Douglasville, Georgia, would be one of the families ultimately caught up in these changing legal and political tides. ${ }^{31}$ In December 1973, the Drummonds became foster parents when a one-month old, mixed-race infant named Timmy was placed with them by the Fulton County Department of Family and Children's Services (DFCS) ${ }^{32}$ While the placement was originally made on an emergency basis, it soon became apparent that Timmy would not be imminently reunited with his biological mother. ${ }^{33}$ In late 1974, the Drummonds expressed an interest in adopting Timmy, who had by then lived with them for close to a year. ${ }^{34}$

There appears to have been no question that the Drummonds provided excellent care for Timmy and loved him deeply. Indeed, the Drummonds' care was described by DFCS personnel as "excellent," "loving," and "extremely competent." 35 Another DFCS worker noted that the Drummonds were "unusually attentive to the child's medical and emotional needs and feel as if they are the 'natural' family." ${ }^{6}$ Nevertheless, DFCS decided that Timmy would be better off with a black couple and that the Drummonds therefore would not be permitted to adopt him. ${ }^{37}$ The Drummonds were informed that they would be permitted to continue as Timmy's foster parents, but that Timmy ultimately would be removed and placed in a black adoptive home. ${ }^{38}$

While the Drummonds originally acquiesced, within months of this initial determination, the Drummonds sought reconsideration of their request to

30 Compare supra note 26 (listing cases that treated certain race-based family law practices as valid based on their benign objectives), with Boone v. Boone, 565 P.2d 337, 339 (N.M. 1977) (" $[\mathrm{R}]$ acial considerations alone cannot properly determine what is in the best interests of children ....”); Commonwealth ex rel. Lucas v. Kreischer, 299 A.2d 243 (Pa. 1973) (ruling that a mother's subsequent interracial marriage was not a compelling reason to deny her custody); and Beazley v. Davis, 545 P.2d 206, 207-08 (Nev. 1976) (arguing that the use of race in adoption should be subject to rigid scrutiny).

31 Drummond v. Fulton Cnty. Dep't of Family \& Children's Servs., 547 F.2d 835, 837, 843 (5th Cir. 1977), vacated and rev'd by 563 F.2d 1200 (5th Cir. 1977) (en banc), cert. denied, 437 U.S. 910 (1978).

32 Id. at 837 . Timmy's mother was white and his father was black. Id.

33 Drummond, 563 F.2d at 1203.

34 Drummond, 547 F.2d at 837.

$35 \mathrm{Id}$.

36 Id. at 841

$37 \mathrm{Id}$. at $837-41$.

$38 I d$. 
adopt Timmy. ${ }^{39}$ And while the Drummonds' social worker was initially instructed to "stall with no encouragement," the Drummonds were ultimately permitted to apply for formal status as adoptive parents. ${ }^{40}$ The DFCS caseworker who evaluated the Drummonds as adoptive parents expressed limited concerns, but ultimately recommended that the Drummonds be permitted to adopt, noting the Drummonds and Timmy's love for each other and the Drummonds' appropriate dealings with issues concerning Timmy's race. ${ }^{41}$ Nevertheless, DFCS adhered to its original decision and removed Timmy from the Drummonds' home when he was two-and-a-half years old. ${ }^{42}$

The Drummonds took legal action, first in federal and then in state court, seeking to prevent (and then reverse) Timmy's removal from their home. ${ }^{43}$ Represented by pioneering civil rights lawyer Margie Pitts Hames ${ }^{44}$ (later joined by additional counsel, including Neil Bradley of the ACLU), the Drummonds contended that the removal of Timmy from their homeon the basis of their race and without any formal hearing-violated the Fourteenth Amendment's guarantees of equal protection and due process. ${ }^{45}$ The DFCS's race-matching policy was, the Drummonds emphasized, virtually categorical and replaced what had been until recently a formal policy of segregation. ${ }^{46}$ Moreover, any alternative arguments raised by DFCS for Timmy's removal (which included the Drummonds' age and relatively racially homogeneous community) had never been articulated by DFCS prior to the initiation of litigation. ${ }^{47}$

\footnotetext{
39 Id. at 841

$40 \mathrm{Id}$.

41 Id. at $843-46$.

$42 \mathrm{Id}$. at $846-48$.

43 Petition for Writ of Certiorari at 7-8, Drummond v. Fulton Cnty. Dep't of Family \& Children's Servs., 437 U.S. 910 (1978) (No. 77-1381) [hereinafter Federal Drummond Petition]. The state proceeding was initiated after the federal district court suggested in its decision that some of the Drummonds' claims might only be vindicated in state court. Id.; see also Drummond v. Fulton Cnty. Dep't of Family \& Children's Servs., 408 F. Supp. 382, 383-84 (N.D. Ga. 1976). These parallel proceedings arguably should have been precluded, but no court ever reached the issue, apparently because it was never raised by the defendants. Memorandum from William J. Brennan, Jr., on Cases Held for No. 76-18o, Smith v. Foster Families, to the Conference 4-5 (June 14, 1977) (on file with the Library of Congress, Byron R. White Papers).

44 Margie Pitts Hames was a civil rights lawyer who litigated several important abortion rights and desegregation cases. Her work is discussed in greater detail in TOMIKO BROWNNAgin, Courage to Dissent: Atlanta AND the LONG History of the Civil RighTS MOVEMENT 409-29 (2011).

45 Drummond, 408 F. Supp. at 382; Federal Drummond Petition, supra note 43, at 7.

46 Federal Drummond Petition, supra note 43, at 11.

47 Drummond, 547 F.2d at 839, 849 .
} 
The Drummonds' claims were quickly rejected in the state courts, and by late 1976 , the Drummonds' state appeal options had been exhausted. ${ }^{48}$ Thus, the Drummonds petitioned the Supreme Court for review of their state case in January $1977,{ }^{49}$ fortuitously just weeks before the case of Smith v. Organization of Foster Families Equality and Reform ${ }^{50}$ (OFFER) was to be argued. OFFER, which addressed the constitutional validity of New York's foster care procedures under the Due Process Clause, raised virtually identical issues as those raised by the Drummonds' due process claims (i.e., whether foster parents were entitled to procedural protections prior to the removal of a foster child from their home). ${ }^{51}$ Because the Georgia Supreme Court had focused almost exclusively on, and rejected, the Drummonds' due process claims, a plaintiff-favorable result in OFFER would arguably have compelled a reversal in Drummond as well. ${ }^{52}$

Unfortunately for the Drummonds, while OFFER did not categorically foreclose the possibility that a foster family might have a constitutional interest warranting procedural protections, the opinion was hardly a resounding endorsement of foster family rights. After expressing some doubt as to whether the Court's due process precedents could be extended to the foster care context at all, the OFFER Court concluded that, in any event, the procedures at issue in OFFER were constitutionally adequate..$^{53}$ As such, the Drummonds' state case-while held by the Court for OFFER ${ }^{54}-$ was denied certiorari days after OFFER was decided. ${ }^{55}$ 1976).

48 Drummond v. Fulton Cnty. Dep't of Family \& Children's Servs., 228 S.E.2d 839, 847 (Ga.

49 Docket Sheet, No. 76-984, Drummond v. Fulton Cnty. Dep't of Family \& Children's Servs. (on file with the Library of Congress, Harry A. Blackmun Papers).

50431 U.S. 816 (1977).

51 Id. at 839 .

52 Memorandum from D.B.A, Law Clerk, on No. 76-984-CSX, Drummond v. Fulton Cnty. Dep't of Family \& Children's Servs., to the Cert Pool 4 (Mar. 21, 1977) (on file with the Library of Congress, Harry A. Blackmun Papers).

53 OFFER, 431 U.S. at 838-856.

54 Docket Sheet, No. 76-984, Drummond v. Fulton Cnty. Dep't of Family \& Children's Servs. (on file with the Library of Congress, Harry A. Blackmun Papers).

55 See OFFER, 431 U.S. at 816 (rendering a decision on June 13, 1977); Drummond v. Fulton Cnty. Dep't of Family \& Children's Servs., 432 U.S. 905 (1977) (denying certiorari on June 20, 1977). The Court did recognize that Drummond also encompassed an independent equal protection claim but apparently believed that claim to be moot because of an erroneous belief that the Drummonds had received-and the defendants had not challenged-the relief they sought as a result of a favorable panel decision from the Fifth Circuit in the federal proceedings. See Memorandum from William J. Brennan, Jr., on Cases Held for No. 76-18o, Smith v. Foster Families, to the Conference 4-5 (June 14, 1977) (on file with the Library of Congress, Byron R. White Papers). In fact, the Defendants had sought, and had been granted, en banc review by the time that certiorari was denied in the state case. Order Granting Rehearing En Banc, Drummond 
The Drummonds' federal case, however, remained pending and would present the race issue much more unambiguously for the Court's review. Ruling en banc in favor of DFCS shortly after the Supreme Court's denial of certiorari in the Drummonds' state case, the Fifth Circuit squarely rejected the Drummonds' equal protection claims, emphatically affirming the constitutional validity of the use of race in adoption. ${ }^{56}$ Noting that "[i]t is a natural thing for children to be raised by parents of their same ethnic background" and that the use of race in the Drummond's case was "simply another facet of finding [the child] the best possible home," the Fifth Circuit held that where, as here, there was "no racial slur or stigma," there was "no discrimination violative of the Fourteenth Amendment."

The Fifth Circuit's en banc opinion thus explicitly distinguished benign uses of race, like adoption, from the Court's race law precedents involving invidious uses of race. ${ }^{58}$ Indeed, the primary authority on which the Fifth Circuit relied was the Supreme Court's splintered decision in United Jewish Organizations of Williamsburgh, Inc. (UJO) v. Carey, the Court's then-recent attempt to grapple with the proper constitutional approach to "benign" uses of race. ${ }^{59}$ While much of UJO's reasoning related to the special constitutional significance of the specific context in which it arose (a redistricting under section 5 of the Voting Rights Act), a plurality opinion-heavily relied on by the Drummond court-focused on the benign nature of the use of race at issue, finding a broader lack of constitutional harm where "no racial slur or stigma" was present. ${ }^{60}$ The Fifth Circuit's decision thus squarely situated itself within the burgeoning constitutional debates over the proper approach to benign uses of race. And indeed, the Supreme Court was just beginning

v. Fulton Cnty. Dep't of Family \& Children's Servs., 547 F.2d 835 (5th Cir. 1977). Ultimately, the Drummonds' panel victory would be entirely reversed by the Fifth Circuit en banc. Drummond v. Fulton Cnty. Dep't of Family \& Children's Servs., 563 F.2d 1200, 1210-11 (5th Cir. 1977) (en banc).

56 Drummond, 563 F.2d at 1204-06.

57 Id. This perception of race-matching in adoption as "natural"-later also articulated by other courts and internally by some of the Supreme Court's justices-may well have arisen in part from strong historical norms in the adoption context of placing children with families that would be perceived as "natural" or biologically related to the child. See, e.g., Michelle M. Mini, Note, Breaking Down the Barriers to Transracial Adoptions: Can the Multiethnic Placement Act Meet This Challenge?, 22 HOFSTRA L. REV. 897, 904 (1994) (observing that "adoptions were often 'hidden'" and that "[i]t was easier for the child to believe that his adoptive parents were actually his biological parents if they all looked the same"); see also Carol Sanger, Developing Markets in BabyMaking: In the Matter of Baby M, 30 HARV. J.L. \& GENDER 67, 73 n.28 (2007) ("[U]ntil the advent of open adoption in the 1990s, the very point of adoption was to simulate biological parenthood all the way down ....").

58 Drummond, 563 F.2d at 1205.

59430 U.S. 144 (1977).

60 Id. at 165-68; see also Drummond, 563 F.2d at 1205 (relying on UJO for the proposition that the Fourteenth Amendment is not violated when there is "no racial slur or stigma"). 
to address in earnest such debates at the time that the Fifth Circuit, en banc, decided Drummond. Several months earlier, in February 1977, the Court had granted certiorari in the affirmative action case of Regents of the University of California v. Bakke. ${ }^{61}$ And while both of the Court's prior precedents addressing benign uses of race-UJO and the earlier case of DeFunis v. Odegaard - were factually or procedurally unusual cases that did not result in a broad circulation of the Justices' substantive views, ${ }^{62}$ Bakke presented a more straightforward opportunity for the Court to elaborate its views. ${ }^{63}$ As such, Bakke was widely perceived-by both the public and the Court itself-as a major opportunity for the Court to clarify its views on the increasingly controversial and political question of how benign uses of race should be treated as a matter of equal protection doctrine. ${ }^{64}$

True to this perception, Bakke in fact spurred, in the fall of 1977 , the first major exchange of views among the Justices on the constitutional standing of affirmative action and other "benign" uses of race. ${ }^{65}$ "Unprecedented" in

61429 U.S. 1090 (1977).

62 See UJO, 430 U.S. 144 (presenting a fractured set of opinions relying on the unique significance of the Voting Rights Act, and a complex array of other factors, to the outcome of the case); DeFunis v. Odegaard, 416 U.S. 312, 319-20 (1974) (per curiam) (finding that the case was moot and therefore failing to reach the substantive arguments).

63 While not entirely uncomplicated, Bakke did involve fewer procedural and factual complications than the arguably fact-bound circumstances at issue in DeFunis and UJO. But see Bench Memorandum on No. 76-811, Regents of the Univ. of Cal. v. Bakke (Sept. 13, 1977) (on file with the Library of Congress, William J. Brennan, Jr., Papers) (raising procedural and factual arguments for why Bakke was a nonideal vehicle for addressing the affirmative action issue).

64 See Paul Delaney, U.S. Brief to Support Minority Admissions, N.Y. TIMES, Aug. 24, 1977, at A1 (noting the sharp divide in society on how the case should be decided); Warren Weaver Jr., Justices Hear Bakke Arguments But Give Little Hint on Decision, N.Y. TimES, Oct. 13, 1977, at A1 (recognizing Bakke as "probably the most significant civil rights case in 24 years"). Several members of the Court also noted internally the need to elucidate the constitutionality of affirmative action programs, and the opportunity that Bakke presented to do so. See, e.g., Memorandum from Lewis F. Powell, Jr., on No. 76-811, Regents of the Univ. of Cal. v. Bakke, to the Conference (Oct. 14, 1977) (on file with the Library of Congress, William J. Brennan, Jr., Papers); Conference Notes of Lewis F. Powell, Jr., on No. 76-811, Regents of the Univ. of Cal. v. Bakke (Oct. 14, 1977) (on file with the Washington and Lee University School of Law, Lewis F. Powell, Jr., Papers).

65 Hundreds of pages of memos were exchanged among the Justices in Bakke prior to the first circulation of any draft opinion, which was an extremely unusual occurrence in the Court's internal practice. See Memorandum from Lewis S. Powell, Jr., on No. 76-811, Regents of the Univ. of Cal. v. Bakke, to the Conference 1 (Jan. 5, 1978) (on file with the Library of Congress, William J. Brennan, Jr., Papers) ("The combination of the Chief's invitation to circulate memoranda and our deferral of a definitive Conference vote have resulted in an unprecedented volume of circulations in this case."). In contrast, UJO and DeFunis occasioned limited written circulations, and very few of those circulations addressed in substance the broader question of how "benign" racial classifications should be addressed. See generally File for No. 75-104, UJO v. Carey (on file with the Library of Congress, William J. Brennan, Jr., Papers); File for No. 73-235, DeFunis v. Odegaard (on file with the Library of Congress, William J. Brennan, Jr., Papers). 
the volume of conference memoranda that it generated, this exchange for the first time made clear where the fault lines among the Justices lay. ${ }^{66}$ As would become much more publicly visible in the Court's later affirmative action precedents, those fault lines sharply divided the Court, with many Justices either strongly supporting or strongly opposing the application of strict scrutiny to race-based affirmative action. ${ }^{67}$ Thus, while the ultimate

66 Memorandum from Lewis S. Powell, Jr., supra note 65.

67 See, e.g., Memorandum from Byron R. White on No. 76-811, Regents of the Univ. of Cal. v. Bakke, to the Conference 2-3 (Oct. 13, 1977) (on file with the Library of Congress, William J. Brennan, Jr., Papers) (espousing no view on the standard of scrutiny, but concluding that the university's program was constitutional); Memorandum from Warren E. Burger on No. 76-811, Regents of the Univ. of Cal. v. Bakke, to the Conference 2-3 (Oct. 21, 1977) [hereinafter Burger Bakke Memo] (on file with the Library of Congress, William J. Brennan, Jr., Papers) (expressing the view that affirmative action must be subject to strict scrutiny and that the Davis program was unconstitutional); Memorandum from William H. Rehnquist on No. 76-811, Regents of the Univ. of Cal. v. Bakke, to the Conference 2, 7-9, 18 (Nov. 10, 1977) [hereinafter Rehnquist Bakke Memo] (on file with the Library of Congress, William J. Brennan, Jr., Papers) (same); Memorandum from William J. Brennan, Jr., on No. 76-811, Regents of the Univ. of Cal. v. Bakke, to the Conference 5, 28-29 (Nov. 23, 1977) (on file with the Library of Congress, William J. Brennan, Jr., Papers) (expressing the view that affirmative action should not be subjected to strict scrutiny, but to a lower "reasonable[ness]" standard and concluding that the university's program was constitutional); Memorandum from Lewis S. Powell, Jr., on No. 76-811, Regents of the Univ. of Cal. v. Bakke, to the Conference 3 (Dec. 1, 1977) [hereinafter Powell Bakke Memo] (on file with the Library of Congress, William J. Brennan, Jr., Papers) (arguing that strict scrutiny was required and that the university's program was unconstitutional, although some use of race might be permissible); Memorandum from Thurgood Marshall on No. 76-811, Regents of the Univ. of Cal. v. Bakke, to the Conference 3 (Apr. 13, 1978) (on file with the Library of Congress, William J. Brennan, Jr., Papers) (arguing against "color-blindness" as the principle by which to decide the case and arguing for the constitutionality of affirmative action); Memorandum from Harry A. Blackmun on No. 76811, Regents of the Univ. of Cal. v. Bakke, to the Conference 11-13 (May 1, 1978) (on file with the Library of Congress, William J. Brennan, Jr., Papers) (implying that strict scrutiny review was not appropriate for "benign" uses of race and expressing the view that the university's program was constitutional, though perhaps just barely); see also Conference Notes of Lewis F. Powell, Jr., on No. 76-811, Regents of the Univ. of Cal. v. Bakke (Dec. 9, 1977) [hereinafter Dec. 9, 1977 Conference Notes] (on file with the Washington and Lee University School of Law, Lewis F. Powell, Jr., Papers) (making clear that although Justice Stewart did not circulate his views in a memorandum, he believed that the Equal Protection Clause categorically precluded adverse government actions based on race). Interestingly, the internal papers suggest that there were potentially five votes on the Court in favor of applying strict scrutiny in Bakke, although the Justices diverged substantially on what the implications of strict scrutiny should be for the Davis policy. Justices Powell, Burger, Stewart, and Rehnquist unwaveringly expressed the opinion that strict scrutiny must be applied to "benign" uses of race. Powell Bakke Memo, supra, at 3-5; Burger Bakke Memo, supra, at 2-3; Rehnquist Bakke Memo, supra, at 7-12; Dec. 9, 1977 Conference Notes, supra. And though Justice White ultimately joined Justice Brennan's opinion applying only intermediate scrutiny, he initially felt strongly for "political" reasons that strict scrutiny should be applied (and confusingly joined portions of Powell's opinion arguing for strict scrutiny, while also joining Brennan's opinion). Memorandum from C.D.L., Law Clerk, to William J. Brennan, Jr. (on file with the Library of Congress, William J. Brennan, Jr., Papers); see Lee Epstein \& Jack Knight, Piercing the Veil: William J. Brennan's Account of Regents of the University of California v. Bakke, 19 YALE L. \& POL'Y REV. 
Bakke opinions showed little division on the constitutional standard-with four of the five Justices to reach the constitutional issue voting for a relaxed, intermediate level of scrutiny-internally, it was clear that deep divisions were emerging on the constitutional propriety of benign uses of race.

Given this backdrop, the en banc Drummond decision-which came to the Court on March 29, 1978, just weeks before Bakke was decided-had obvious considerations favoring a grant of certiorari. ${ }^{68}$ Most notably, the Drummond court's standard-one of no constitutional scrutiny for "benign" uses of race-was one that not even the Court's race liberals were prepared to endorse. ${ }^{69}$ It thus provided an opportunity for the Court to speak on a unified basis regarding at least some facet of the complex and unsettled treatment of benign uses of race. Moreover, the Drummond Court's reliance on the UJO plurality, ${ }^{70}$ a decision that would be contradicted by both of the constitutionally based opinions issued in Bakke, ${ }^{71}$ made the case an obvious candidate for a Grant, Vacate, and Remand (GVR) (i.e., a direction to the lower court to reexamine the issue in view of later, more authoritative precedent)..$^{72}$

341, 358, 362-63, 368 (2001) (reproducing Justice Brennan's narrative regarding the Court's internal consideration of Bakke and noting Justice White's desire for strict scrutiny); see also Regents of the Univ. of Cal. v. Bakke, 438 U.S. 265, 287-91 (1978) (Powell, J., concurring) (rejecting, in a part of the opinion joined by Justice White, the notion that something less than strict scrutiny should apply); id., 438 U.S. at 356-59 (Brennan, J., concurring) (finding, in an opinion joined by Justice White, that only intermediate scrutiny was required).

68 Federal Drummond Petition, supra note 43; see also Memorandum from Warren E. Burger on No. 77-1381, Drummond v. Fulton Cnty. Dep't of Family \& Children's Servs., to the Conference (June 5, 1978) (on file with the Library of Congress, Thurgood Marshall Papers) (noting that Drummond was to be discussed at the Court's June 8, 1978, conference); see also Bakke, 438 U.S. 265 (indicating that the case was decided June 28,1978 ).

69 See Drummond v. Fulton Cnty. Dep't of Family \& Children's Servs., 563 F.2d 1200, 1205 $\left(5^{\text {th }}\right.$ Cir. 1977) (en banc) (concluding categorically that the "use of race as one of the factors [in placing a child for adoption] is legitimate," based in part on the Court's reading of UJO as mandating that where "there is 'no racial slur or stigma with respect to whites or any other race' there is no discrimination violative of the Fourteenth Amendment" (quoting UJO v. Carey, 430 U.S. 144, 165 (1977))); see also Bakke, 438 U.S. at 356-59 (Brennan, J., concurring) ("On the other hand, the fact that this case does not fit neatly into our prior analytic framework for race cases does not mean that it should be analyzed by applying the very loose rational-basis standard of review that is the very least that is always applied in equal protection cases.").

70 UJO, 430 U.S. at 165.

71 See supra note 67 (setting out the Justices' views regarding the appropriate standard of review in Bakke).

72 Sara C. Benesh, GVRs and Their Aftermath in the Seventh Circuit and Beyond, 32 S. ILL. U. L.J. 659, 662-64 (2008). 
Despite these arguable strengths, the Court denied certiorari in Drummond less than ten days before Bakke was decided. ${ }^{73}$ And while available records do not conclusively establish the reasons for the denial, the cert pool memo-drafted by one of Justice Blackmun's law clerks and circulated to Justices Blackmun, Burger, White, Powell, and Rehnquist-suggests that, at least to some, adoption was simply different as a matter of common sense. ${ }^{74}$ Thus, Justice Blackmun's clerk asserted boldly without citation, "As to petrs' equal protection claims, acceptance of petrs' argument that race should not be considered in making adoption decisions, would defy the nearunanimous practice of state adoption agencies and the consensus among psychologists and sociologists." 75 Although recognizing the potential doctrinal overlaps with Bakke (overlaps that had been specifically highlighted by the Drummonds in their petition for certiorari), the author of the memo dismissed Drummond without explanation as "aris[ing] in such different factual context [sic] that I believe a hold is unwarranted."76

Not all of the Justices agreed with this assessment. Justices White and Brennan voted to grant certiorari in Drummond, and even took the unusual step of noting their disagreement in the published order denying certiorari review. ${ }^{77}$ And two other Justices, Marshall and Stevens, struggled with their votes in Drummond, initially voting to grant certiorari but later changing

73 Drummond v. Fulton Cnty. Dep't of Family \& Children's Servs., 437 U.S. 910 (1978); Bakke, 438 U.S. at 265 .

74 Memorandum from K.E., Law Clerk, on No. 77-1381, Drummond v. Fulton Cnty. Dep't of Family \& Children's Servs., to Cert Pool 13 (June 1, 1978) (on file with the Library of Congress, Harry A. Blackmun Papers). As to the Drummonds' due process claim, the memorandum recommended a denial because, inter alia, the case was unusual insofar as the agency was initially unaware that Timmy was biracial and thus " $t]$ he presumably unusual fact that resps were originally unaware of the child's race puts resps' subsequent decision to remove Timmy from the Drummonds' care in a very different perspective from the normal decision to re-place a child." Id. at $12-13$.

75 Id. at 13. Justice Blackmun's marked up version of the memo did not comment directly on the passage discussing the Drummonds' equal protection claims, but he did place a check mark next to it, $i d$. at 13 , suggesting agreement with the point being made.

76 Id. at 13; see also Federal Drummond Petition, supra note 43, at 25-26; cf. Memorandum from E.S., Law Clerk to Thurgood Marshall, on the legislative history of Title VI of the Civil Rights Act of 1964 (circulated to the Conference by Justice Marshall on Oct. 28, 1977) (on file with Library of Congress, William J. Brennan, Jr., Papers) (discussing the legislative history of Title VI as it relates to affirmative action programs and noting that an amendment to Title VI that would have "expressly authorized federal grantees to take race into account in placing children in adoptive and foster homes" was rejected as unnecessary, thus supporting the inference that Congress did not expect to eliminate all potentially benign uses of race by enacting Title VI).

77 See Drummond, 437 U.S. 910; see also Ryan C. Black \& Ryan J. Owens, Analyzing the Reliability of Supreme Court Justices' Agenda-Setting Records, 30 JUST. SYS. J. 254, 256 (2009) (noting that votes of Justices as to certiorari are rarely published). 
their votes to deny. ${ }^{78}$ But for the Court's race conservatives - those who had argued most stridently that race restrictions of any kind must be subject to the most rigorous constitutional scrutiny during the debates on BakkeDrummond apparently did not present an appealing candidate for review. ${ }^{79}$ As a result, on June 15, 1978, the Drummonds' long legal crusade came quietly to an end with the denial of their petition for certiorari. ${ }^{80}$

\section{DRUMMOND TO PALMORE: $1978-1984$}

The lower courts' treatment of race in the family law context, already divided at the time that Drummond was decided, would become even more so in the period following the Court's denial of certiorari in Drummond. Indeed, during the six-year period between Drummond and the Supreme Court's next major race family law case (Palmore v. Sidoti), the lower courts would issue opinions that were almost equally divided in affirming and rejecting government uses of racial criteria in the family. ${ }^{81}$ This division, moreover, was not simply reflective of differing bottom line results, but instead extended to virtually every feature of race family law litigation. Thus, deep divisions emerged in the post-Drummond era about whether the use of race in family law (by public agencies or courts) was ever permissible;

78 See Docket Sheet, No. 77-1381, Drummond v. Fulton Cnty. Dep't of Family \& Children's Servs. (on file with the Library of Congress, Harry A. Blackmun Papers) (showing a change in Justice Marshall's vote from "grant" to "deny" and noting that ultimately only "B-W wd G"-i.e., only Brennan, and White voted to grant cert despite the fact that Stevens is shown to have voted for "grant").

79 Id. (showing that none of the Justices who endorsed strict scrutiny in the internal debates over Bakke, including Chief Justice Burger and Justices Rehnquist, Stewart, and Powell, voted in favor of review in Drummond).

80 Drummond, 437 U.S. 910.

81 A significant number of cases during this time affirmed lower court or agency decisions that relied in part on race. See, e.g., Russell v. Russell, 399 N.E.2d 212 (Ill. App. Ct. 1979) (affirming a change in custody that considered the mother's interracial marriage); In re Marriage of Kramer, 297 N.W.2d 359 (Iowa 1980) (holding that while race can be a factor, it was improperly used in the trial court's decision, but nevertheless affirming the trial court's decision on other grounds); In re Davis, 465 A.2d 614 ( $\mathrm{Pa} .1983$ ) (allowing the consideration of race in adoption and foster care matters). On the other hand, several decisions during this time also reversed lower court or agency uses of race or rejected litigant requests to make race a dispositive factor. See, e.g. In re Mikelson, 299 N.W.2d 670, 673-74 (Iowa 1980) (considering the parents' connection to a racial community in custody disputes over adoptive biracial children, but ultimately deeming it nondispositive); Edel v. Edel, 293 N.W.2d 792 (Mich. Ct. App. 1980) (rejecting a change in custody based on an interracial relationship); In re Custody of Temos, 450 A.2d 111 (Pa. Super. Ct. 1982) (noting that a change in custody based on an interracial relationship was inappropriate). 
if so, to what extent; and what, if anything, was the role of constitutional adjudication (as opposed to state family law) in resolving these disputes. ${ }^{82}$

These divisions, moreover, were not restricted simply to the adoption issue presented to the Court in Drummond (or to its closely related cousin, interracial foster care placements). Two other race-based family law practices continued to trouble the courts during the pre-Palmore time period, and both occasioned similarly divisive responses. Thus, the use of race as a "plus factor" for minority parents in custody disputes between interracial parents, as well as the use of a parent's post-divorce interracial marriage as a basis for denying custody, resulted in similarly divided responses from the courts..$^{83}$ And, as in the adoption context, these divisions extended far beyond surface outcomes to fundamental disagreements about the legal principles under which race family law claims should be adjudicated.

It was during this unsettled time that Linda Palmore and her exhusband, Anthony Sidoti, would find themselves litigating over whether the race of Linda's new husband should result in the loss of her custody of their young daughter. ${ }^{84}$ Upon the couple's divorce in 1980 , Linda had been awarded custody of their then two-year-old daughter, Melanie. ${ }^{85}$ But just over a year later, Linda and Anthony were back in court, with Anthony

82 See, e.g., In re Petition of R.M.G., 454 A.2d 776, 784-94 (D.C. 1982) (concluding that strict scrutiny was required under the Equal Protection Clause and reversing and remanding the lower court determination because its use of race did not meet the strictures of strict scrutiny); Palmore v. Sidoti, 426 So.2d 34 (Fla. Dist. Ct. App. 1982) (relying on the race of the mother's spouse as a basis for a change in custody); Russell, 399 N.E.2d at 213-15 (concluding that the lower court complied with state law in relying on the mother's interracial marriage as one factor among many); In re Mikelson, 299 N.W.2d at 673-74 (stating that race can be a consideration under state custody law, albeit not a controlling one); In re Kramer, 297 N.W.2d at 360-63 (affirming the lower court decision relying on race, but also stating in dicta that the lower court's use of race was impermissible as a matter of state law); Edel, 293 N.W.2d at 794-95 (concluding that the race of the mother's fiancé was an improper consideration-apparently as a matter of state law-and remanding for a reassessment without consideration of that factor); Farmer v. Farmer, 109 Misc. 2d 137, 140-47 (N.Y. Sup. Ct. 1981) (noting that race can be a consideration under state custody law, but finding that here it was not controlling); In re Haven, No. C-780343, 1979 Ohio App. LEXIS 9744, at *1-15 (Ohio Ct. App. Aug. 1, 1979) (finding that the use of race in adoption was constitutionally permissible even where based on a policy of "favoring the adoption of white children by whites and black children by blacks"); In re Davis, 465 A.2d at 623-29 (concluding that the lower court erred in not considering race in a foster care/adoption dispute and finding that consideration of a race as a factor is constitutional); Temos, 450 A.2d at 119-22 (finding that an interracial relationship could not be a basis for a custody modification, but not specifying whether the ruling was based on constitutional principles, state law, or both).

83 See supra note 82.

84 Petition for Writ of Certiorari at i, 3-4, Palmore v. Sidoti, 466 U.S. 429 (1984) (No. 821734) [hereinafter Palmore Petition].

$85 \mathrm{Id}$. at 3 . 
seeking to obtain custody. ${ }^{86}$ Contending that Linda (who was white) "ha[d] not acted in the best interest and welfare of [Melanie] in that she ha[d] had a black male living with her for some period of time," and that she had also been neglectful in allowing Melanie to contract lice and wear clothes stained with mildew, Anthony requested that he be awarded custody of Melanie, who was then four. ${ }^{87}$

The trial court-while rejecting Anthony's suggestions that Linda had been neglectful of Melanie's health or clothing-found that Linda's actions in dating a black man outside of wedlock were "of some significance." 88 The court observed, "despite the strides that have been made in bettering relations between the races in this country, it is inevitable that Melanie will, if allowed to remain in her present situation... suffer from the social stigmatization that is sure to come." 89 It thus concluded that Melanie's best interests would be served by living in her father's (monoracial) household, and granted his request for a custody modification..$^{90}$

This order by the trial court-issued six months after Anthony Palmore's initial petition for modification-was summarily affirmed by the Florida District Court of Appeals in December 1982. ${ }^{91}$ As a result, under Florida law, the Florida Supreme Court lacked jurisdiction to hear any further appeal. ${ }^{92}$ Thus, by early 1983 , Linda Palmore's state court appeal options had been exhausted. ${ }^{93}$ Her attorneys, after unsuccessfully seeking a stay from the Florida District Court of Appeals, petitioned the United States Supreme Court directly for a stay of Melanie's removal from Linda's custody. ${ }^{94}$

Because the case arose in the geographical jurisdiction of the Eleventh Circuit, the Palmore v. Sidoti stay application was initially directed to Justice Powell, ${ }^{95}$ the Circuit Justice for the Eleventh Circuit. ${ }^{96}$ Arguably, this was a

\footnotetext{
$86 \mathrm{Id}$.

$87 \mathrm{Id}$. at 4 .

$88 I d$. at 26.

$89 \mathrm{Id}$. at 26-27.

$90 \mathrm{Id}$. at 27.

91 Palmore v. Sidoti, 426 So. 2 d 34 (Fla. Dist. Ct. App. 1982), rev'd, 466 U.S. 429 (1984); Palmore Petition, supra note 84 , at * 5 -6.

92 Memorandum from Caldwell, Law Clerk, on No. A-664, Palmore v. Sidoti, to the Conference 3 n.2 (Feb. 16, 1983) (on file with the Library of Congress, Thurgood Marshall Papers).

$93 \mathrm{Id}$. at 3.

94 Palmore Petition, supra note 84, at 1, 9-10, 30.

95 Memorandum from Caldwell, supra note 92 (making clear that Justice Powell adjudicated the original Palmore stay).

96 See Lois J. Scali, Prediction-Making in the Supreme Court: The Granting of Stays by Individual Justices, 32 UCLA L. REV. 1020, 1025 n.33 (1985) (setting out the identity of the individual Justices
} 
good draw for the Palmore side of the case. In Bakke, Powell had affirmed a strong commitment to strictly scrutinizing all uses of race, including even those adopted with putatively benign motives. ${ }^{97}$ In addition, in Fullilove $v$. Klutznik, decided two years after Bakke, Powell had reiterated his commitment to the strict scrutiny standard of review, despite finding the specific use of race at issue to be constitutionally valid. ${ }^{98}$ Thus, the state court's decision in Palmore - uncritically relying on racial considerations without any form of constitutional scrutiny-seemed to facially conflict with Powell's publicly expressed views on race law doctrine. ${ }^{99}$

Powell, however, apparently regarded the Palmore case as a wholly undesirable matter for the Court to take up. While the reasons are not clear from the internal documents, his notes on the stay have repeated annotations suggesting his antipathy for the case: "This is the white/black marriagechild custody case. We should not get into this." ${ }^{100}$ And again, on a later date: "Deny[.] This is [the] case where petr-a white woman remarried a black. She \& first husband are fighting over child custody . . .."101

Under Supreme Court rules, however, Powell was not the final word on whether Linda Palmore's stay request would be granted. Then, as now, a stay applicant may reapply to any other Justice following the denial of a stay. ${ }^{102}$ Thus, following Powell's initial denial of the stay, Linda Palmore reapplied to Justice Marshall, who, in accordance with Court convention, referred the matter to the full Court. ${ }^{103}$ There, her stay request piqued

assigned to hear stays from particular circuits at roughly the time that the Palmore stay would have been considered).

97 See Regents of the Univ. of Cal. v. Bakke, 438 U.S. 265, 287-305 (1978) (Powell, J.) (stating that all racial and ethnic distinctions must be subjected to strict scrutiny).

98448 U.S. 448, 496-99, 507 (1980) (Powell, J., concurring) (stating that adherence to a strict scrutiny standard is "important and consistent with precedent").

99 Palmore Petition, supra note 84, at 26-27. Of course, as the work of Anders Walker has unearthed, Powell's views on race and the law were complex and derived from a view that racial separatism and segregation could potentially foster genuine pluralism. Anders Walker, Diversity's Strange Career: Recovering the Racial Pluralism of Lewis F. Powell, Jr., 50 SANTA ClARA L. REV. $647,648,672-77$ (2010). Viewed through this lens, it is perhaps less surprising that Powell did not view racial integration within the family as a particularly desirable matter for the Court to take up.

100 Handwritten Notation on Memorandum from Alexander L. Stevas, Clerk of Court, on No. A-664, Palmore v. Sidoti, to the Conference (Feb. 18, 1983) (on file with the Washington and Lee University School of Law, Lewis F. Powell, Jr., Papers).

101 Memorandum from Caldwell, supra note 92; Handwritten Notation on Docket Sheet, A664, Palmore v. Sidoti (Mar. 3, 1983) (on file with the Washington and Lee University School of Law, Lewis F. Powell, Jr., Papers).

102 SUP. CT. R. 22.

103 Memorandum from Caldwell, supra note 92; see also Scali, supra note 96, at 1021 (explaining that such reapplications are almost universally referred to the full court and subsequently denied). 
greater interest, with six of the Justices-including all of the Court's race liberals-"calling for a response" (i.e., requesting that the Respondent submit a statement in response to the stay application). ${ }^{104}$

The resulting response was, in the words of Powell's law clerk, "miserable." 105 While contending that other, nonracial factors also influenced the trial court's decision, Sidoti conceded that race was a salient factor. ${ }^{106}$ Additionally, Sidoti's primary constitutional argument-that Florida authority held only "that the effect of an interracial marriage upon a particular child is one of the many factors that may be considered in determining the best interest of the child"107_-was arguably in significant tension with other constitutional decisions of the Court, which had recognized that even partial influence, where dispositive, violates the Constitution. ${ }^{108}$

On the other hand, the response also had, according to Powell's clerk, "[o]ne key point." 109 "The mandate [was] issued in February" and thus by the time the full Court considered the issue, Melanie was already in Sidoti's custody. ${ }^{110}$ As Powell's clerk observed, "therefore by this Court's own delay, the application appears moot - the irreparable injury has occurred already."111 He thus concluded that "TM [Thurgood Marshall] blew it," an apparent reference to Justice Marshall's desire (contrary to Powell's own) to have the Court grant a stay. ${ }^{112}$

104 See Docket Sheet, A-664, Palmore v. Sidoti (Feb. 18, 1984) (on file with Library of Congress, William J. Brennan, Jr., Papers) (identifying Justices Brennan, White, Marshall, Blackmun, Stevens and O'Connor as calling for a response, and Chief Justice Burger and Justices Powell and Rehnquist as voting against).

105 Handwritten Notation of M.N. on Docket Sheet, No. A-664, Palmore v. Sidoti (Mar. 2, 1983) (on file with the Washington and Lee University School of Law, Lewis F. Powell, Jr., Papers).

106 See Memorandum of A.S.M., Law Clerk, to Harry A. Blackmun, on No. A-664, Palmore v. Sidoti (Mar. 3, 1983) (on file with Library of Congress, Harry A. Blackmun Papers).

107 Id. (emphasis added).

108 See Mt. Healthy City Sch. Dist. v. Doyle, 429 U.S. 274, 287 (1977) (holding that partial influence of an unconstitutional consideration, where dispositive, violates the Constitution); Village of Arlington Heights v. Metro. Hous. Dev. Corp., 429 U.S. 252, 270 n.21 (1977) (explaining that where race was a motivating factor, a defendant could avoid constitutional liability only by showing that "the same decision would have resulted even had the impermissible purpose not been considered"). But see Banks, Color of Desire, supra note 5, at 904-05 (describing a number of contexts in which the courts have treated classifications involving "race as a factor" as if they did not entail a racial classification).

109 Handwritten Notation of M.N. on Docket Sheet, supra note 105.

$110 \mathrm{Id}$.

111 Id.; see also Memorandum from A.S.M., Law Clerk, on No. A-664, Palmore v. Sidoti, to Harry A. Blackmun (Mar. 3, 1983) (on file with Library of Congress, Harry A. Blackmun Papers) (expressing a similar sentiment regarding the case's mootness).

112 Handwritten Notation of M.N. on Docket Sheet, supra note 105; see also Memorandum from Thurgood Marshall on No. A-664, Palmore v. Sidoti, to the Conference (Feb. 18, 1983) (on 
Indeed, when the Court voted on the merits of the stay two days later, it overwhelmingly voted to deny. ${ }^{113}$ Only Justice Stevens, in a move he would later note as a particular point of pride, voted to grant the stay. ${ }^{114}$ And while the Court would ultimately grant certiorari and rule unanimously in Linda Palmore's favor-elevating her case to canonical status-for Palmore herself, the stay decision would prove to be the one that mattered. During the two years following Melanie's removal, Palmore would see her daughter only once, on a court-ordered visit three months after the Supreme Court ruled in her favor. ${ }^{115}$ By 1986, more than two years after her putative victory in the Supreme Court, Palmore was reportedly preparing to sign papers awarding custody of Melanie to her husband in exchange for visitation rights, ${ }^{116}$ still not having reestablished even regular contact with her daughter. ${ }^{117}$

At the time, however, Linda Palmore could not have known that a Supreme Court decision in her favor would ultimately have little effect. Thus, in April 1983, shortly after the denial of the stay by the full Court, she petitioned for a writ of certiorari. ${ }^{118}$ Contending that the trial court rested its decision solely on the race of her husband, Palmore argued that, under Loving v. Virginia, "[t]he equal protection and due process clauses of the Fourteenth Amendment... prohibit a court... from relying upon a subsequent interracial marriage ... as a ground for ordering a change in custody." ${ }^{119}$ She further observed that her case was different from others where the Court had approved the use of race, noting that " $[\mathrm{n}] \mathrm{o}$ modern decision of this Court has sustained a racial classification which burdens or stigmatizes black citizens on the basis of race." ${ }^{120}$

Despite the relatively extended discussion that the Palmore stay application had prompted, the cert pool memorandum addressing the Palmore petition-drafted by one of Justice Powell's law clerks and circulated to Justices Powell, O'Connor, Rehnquist, Blackmun, Burger, and White-

file with the Library of Congress, Thurgood Marshall Papers) (indicating that Marshall would grant the stay).

113 Docket Sheet, No. A-664, Palmore v. Sidoti (on file with the Washington and Lee University School of Law, Lewis F. Powell, Jr., Papers); Palmore v. Sidoti, 460 U.S. 1018 (1983) (denying stay).

114 Docket Sheet, No. A-664, Palmore v. Sidoti, supra note 113; see also John Paul Stevens, Learning on the Job, 74 FORDHAM L. REV. 1561, 1564 (2006).

115 Andrew M. Williams, Domestic News, Associated Press, Nov. 21, 1984, available at LexisNexis Academic.

116 TV Drama 'Fictionalized' Custody Fight, Lawyer Says, DALl. Morning News, Oct. 8, 1986, at 34A.

117 Id.

118 Palmore Petition, supra note 84.

119 Id. at 17 .

$120 \mathrm{Id}$. at 16 
devoted a mere two-and-a-half double-spaced pages to Palmore's request for certiorari review. ${ }^{121}$ Noting that "[i]t appears ... that the principal reason for denying the stay was that the case did not appear cert-worthy to four Justices," Powell's clerk observed that "[n]othing has happened in the last three months to make this case any more cert-worthy now than it was then." ${ }^{122}$ Without discussing the merits or independent cert-worthiness of Palmore's claims further, Powell's clerk recommended that the Court deny review. ${ }^{123}$

This framing of the issue, and of the stay proceedings as having been predicated on Palmore's merits, was arguably at least partially misleading. After all, just months earlier, Powell's chambers had contended that the principal reason for denying the stay was its mootness, an issue material only to the stay proceedings' requirement of "irreparable injury." 124 Nevertheless, the pool memorandum drafted by Powell's law clerk failed to even mention the different standards that applied to a stay or the possibility that those standards cut against affording too much weight to the initial stay proceedings. ${ }^{125}$

On the other hand, it appears that Powell's clerk was in fact correct that there was not widespread support on the Court for a grant of certiorari in Palmore. At first, only two Justices, Brennan and Stevens, voted unequivocally to grant certiorari review. ${ }^{126}$ Two other Justices, Marshall and Blackmun, cast "Join-3" votes, signifying that their vote should count as a grant vote only if there were three others in favor. ${ }^{127}$ Thus, Palmore squeaked by on the narrowest of margins, granted review only as a result of a change in Justice Marshall's vote from a "Join 3" to a "Grant" after the initial polling. ${ }^{128}$

The Court's reluctance to grant review-despite Palmore's presentation of an issue that many today would characterize as having obvious constitutional

121 Memorandum from M.S., Law Clerk, on No. 82-1734, Palmore v. Sidoti, to the Cert Pool (June 9, 1983) (on file with the Library of Congress, Harry A. Blackmun Papers) [hereinafter Palmore Cert Pool Memo].

122 Id. at 3 .

123 Id.

124 Handwritten Notation of M.N. on Docket Sheet, supra note 105; see also Memorandum from Caldwell, supra note 92 (setting out the four requirements needed for a stay to be granted, including irreparable injury).

125 Palmore Cert Pool Memo, supra note 121, at 3.

126 Docket Sheet, No. 82-1734, Palmore v. Sidoti (on file with the Library of Congress, Harry A. Blackmun Papers); Docket Sheet, No. 82-1734, Palmore v. Sidoti (on file with the Washington and Lee University School of Law, Lewis F. Powell, Jr., Papers).

127 See supra note 126; see also Ryan J. Owens \& David A. Simon, Explaining the Supreme Court's Shrinking Docket, 53 WM. \& MARY L. REV. 1219, 1239 (2012) (explaining that a "Join-3" is counted as a "Grant" vote only if at least three other Justices vote in favor of granting review).

128 Four Justices must vote in favor in order for a case to be granted certiorari. Owens \& Simon, supra note 127 , at 1227 . 
significance-may have reflected factors unrelated to the Justices' views of the fundamental legal question it presented. The appellate court did not write a decision in Palmore, and thus there was only the trial court's terse order for the Court's review. ${ }^{129}$ Moreover, it was not entirely clear whether the interracial marriage issue had been the sole consideration in the change of custody, although all of the Justices seem to have agreed that it was the predominant factor. ${ }^{130}$ In addition, the lower courts - both the trial court in Palmore itself and others that had addressed the same issue-had typically ignored constitutional arguments raised by the parties, instead relying on state custody law. ${ }^{131}$ Thus, while Palmore was typical of the period's race family law cases in both substance and format, it was arguably a nonideal vehicle for certiorari review by traditional Supreme Court standards. ${ }^{132}$

But there were also substantive reasons-later articulated during the course of the Palmore proceedings - why many of the Justices may have seen Palmore as a troubling case to take up. Among other things, while the Justices widely viewed the removal of a child from a natural parent based on that parent's interracial marriage (the issue in Palmore) to be constitutionally impermissible, they did not share the same view of other remaining uses of race in family law, particularly adoption. ${ }^{133}$ As such, several of the Justices

129 Palmore Petition, supra note 84 , at 21-24; see also Memorandum from Caldwell, supra note 92 (noting that this factor made the case somewhat less appealing for review, although review was probably warranted); Memorandum from M.E.N., Law Clerk, on No. A-664, Palmore v. Sidoti, to Lewis S. Powell (on file with the Washington and Lee University School of Law, Lewis F. Powell, Jr., Papers) (noting the absence of an appellate opinion as a reason to deny review in the case); Typewritten Notation, Palmore Cert Pool Memo, supra note 121, at 1 (noting this issue but recommending a "Grant").

130 Palmore Petition, supra note 84, at 21-24; see also Memorandum from M.E.N., supra note 129 (noting this concern, but also noting that the interracial marriage "was decisive to the courts below"); Handwritten Notation on Memorandum from M.S., Law Clerk, on No. 82-1734, Palmore v. Sidoti, to the Cert Pool (Sept. 19, 1983) (on file with the Washington and Lee University School of Law, Lewis F. Powell, Jr., Papers) (noting this concern, but also noting that racial factors appear to have predominated); Memorandum from Caldwell, supra note 92 (same); cf. Memorandum from Warren E. Burger to William J. Brennan (Mar. 21, 1984) (on file with the Library of Congress, William J. Brennan, Jr., Papers) (resisting Brennan's efforts to argue that the draft opinion should be modified to broadly prohibit the use of race as a factor on the grounds that "[r]ace was the dispositive basis and that surely is clear").

131 Palmore Petition, supra note 84, at 21-24; see also supra note 82.

132 See supra notes 129-131 and accompanying text; see also Memorandum from A.S.M., Law Clerk, on No. A-664, Palmore v. Sidoti, to Harry A. Blackmun 2 (Mar. 3, 1983) (on file with the Library of Congress, Harry A. Blackmun Papers) (suggesting that "it might be better to await a clear constitutional conflict before granting a case involving the problem [of interracial marriage and child custody cases]").

133 See Docket Sheet, No. 82-1734, Palmore v. Sidoti (on file with the Library of Congress, William J. Brennan, Jr., Papers) (documenting the unanimous vote in Palmore on the merits); see also Memorandum from Lewis S. Powell on No. 82-1734, Palmore v. Sidoti 2 (Jan. 31, 1984) (on file 
(largely the Court's race conservatives), ${ }^{134}$ expressed deep concerns that a ruling in favor of Linda Palmore might be read to prohibit the restriction of transracial adoptions. ${ }^{135}$ Indeed, this issue-whether a ruling precluding the

with the Washington and Lee University School of Law, Lewis F. Powell, Jr., Papers) (showing that although Powell opposed granting review, he agreed that the lower court's use of race was "invalid" once the petition for certiorari was granted); cf. Post-Argument Memorandum from K.R.B., Law Clerk, on No. 82-1734, Palmore v. Sidoti 2 (Feb. 22, 1984) (on file with the Library of Congress, Byron R. White Papers) (arguing that while the lower court decision might be flawed because of the lack of evidence of harm, a categorical rule was unjustified because "I do not understand why the Constitution should consign [a child] to an inferior home on the ground that factually relevant, but legally irrelevant, criteria cannot be considered").

134 For a discussion of which Justices articulated concerns regarding the adoption issue and their broader positions at the time regarding the necessity of subjecting putatively benign uses of race to strict scrutiny, see infra notes $135-42$. See generally supra note 12 for a definitional discussion of how specific Justices were classified as "race conservatives," "race liberals," or "race moderates," for the purposes of this Article.

135 See, e.g., Blackmun Conference Notes on No. 82-1734, Palmore v. Sidoti [hereinafter Blackmun Conference Notes, Palmore v. Sidoti] (on file with the Library of Congress, Harry A. Blackmun Papers) (noting the following Justices' remarks-Chief Justice: "W[oul]d n[ot] touch adoption"; Rehnquist: "Eschew adoption"; Stevens: "[A]doption agencies do try to accom[modate]"); Brennan Conference Notes on No. 82-1734, Palmore v. Sidoti [hereinafter Brennan Conference Notes, Palmore v. Sidoti] (on file with the Library of Congress, William J. Brennan, Jr., Papers) (including the following remarks-Chief Justice: "This is custody, not adoption, which I wouldn't touch"; Powell: "Agree with CJ"; Rehnquist: "Agree with CJ"); Oral Argument Notes of Justice Powell on No. 82-1734, Palmore v. Sidoti [hereinafter Palmore Oral Argument Notes] (on file with the Washington and Lee University School of Law, Lewis F. Powell, Jr., Papers) (“Adoption is different."); Powell Conference Notes on No. 72-1734, Palmore v. Sidoti [hereinafter Powell Conference Notes, Palmore v. Sidoti] (on file with the Washington and Lee University School of Law, Lewis F. Powell, Jr., Papers) (noting the following-Chief Justice: "No[t] like an adoption case-this would be different"; White: "Agree with CJ"; Rehnquist: "Avoid discussion of adoption-not here"; Stevens: "If this were an adoption case, it would be different. Biological considerations are important"); see also Post-Argument Memorandum from K.R.B., supra note 133, at 3 (expressing concerns that a broadly written opinion in Palmore would interfere with the common practice of adoption agencies to place children with parents of the same race as the child, and might also interfere with similar practices in the custody context); Memorandum from E.T. on No. 72-1734, Palmore v. Sidoti, to Harry A. Blackmun 8 (Feb. 17, 1984) (on file with the Library of Congress, Harry A. Blackmun Papers) (expressing the view that "adoption is different"). This attention to adoption is perhaps unsurprising given that the Respondent in Palmore repeatedly attempted to draw parallels to the adoption context in arguing in support of the use of race at issue in Palmore. See, e.g., Brief for Respondent in Opposition to Petition for Writ of Certiorari at 5-7, Palmore v. Sidoti, 466 U.S. 429 (1984) (No. 82-1734) (relying on Drummond to argue that the Court had specifically rejected "[a]ny claim that the Fourteenth Amendment prohibits a state from considering racial attitudes in determining the child's welfare"); Brief for Respondent at *6-13 \& n.8 \& n.23, \& *14 n.33, Palmore, 466 U.S. 429 (No. 82 1734) (seeking to equate the type of classification at issue in Palmore with the adoption context, and to distinguish both from the type of classification at issue in Loving); Oral Argument Transcript, Palmore v. Sidoti, No. 82-1734 [hereinafter Palmore Oral Argument Transcript], available at http://www.oyez.org/cases/1980-1989/1983/1983_82_1734/\#transcript-text554 (drawing parallels to adoption, in argument for the state, at oral argument). The Solicitor General's brief in Palmore also noted possible parallels to adoption but argued that there were potential distinguishing factors that 
use of race in Palmore would compel a similar result in the adoption context-was of such central concern to the Justices that it was among the first questions posed to Linda Palmore's counsel at oral argument. ${ }^{136}$ (Counsel assured the Justices that adoption-which involved "a person who was not a biological parent" - was "much different than [what] we have here."137)

At the conference for Palmore, the adoption concern again surfaced, with several of the Court's race conservatives (and Justice Stevens) arguing that the Palmore decision should not be drafted in such a way as to extend to adoption. ${ }^{138}$ Adoption, those Justices noted, was "different." 139 "Biological considerations," they argued, mattered in the adoption context and might mandate a different result. ${ }^{140}$ They thus profoundly differentiated between the specific custody issue before the Court and adoption, which several Justices opined they "wouldn't touch." ${ }^{141}$ Ultimately, three Justices (Burger, Rehnquist and Stevens) all specifically noted in conference that the decision in Palmore should be drafted to avoid the adoption issue, a sentiment with which Justices White and Powell (and possibly also Justice O'Connor) apparently agreed. ${ }^{142}$

could allow the Court to strike down the use of interracial marriage in custody while leaving adoption open to future consideration. Brief for the United States as Amicus Curiae Supporting Petitioner, at 21 n. 8, Palmore, 466 U.S. 429 (No. 82-1734) [hereinafter United States Palmore Brief]; see also Memorandum from E.T., supra note 135 (discussing the Solicitor General's position on this issue).

136 Palmore Oral Argument Transcript, supra note 135.

137 Id.

138 Blackmun Conference Notes, Palmore v. Sidoti, supra note 135; Brennan Conference Notes, Palmore v. Sidoti, supra note 135; Powell Conference Notes, Palmore v. Sidoti, supra note 135.

139 Supra note 138. By contrast, Justice Blackmun expressed disagreement with this point and believed that an "[a]doption case may not be different." Powell Conference Notes, Palmore v. Sidoti, supra note 135 .

140 Powell Conference Notes, Palmore v. Sidoti, supra note 135; see also supra note 138.

141 Brennan Conference Notes, Palmore v. Sidoti, supra note 135; see also supra note 138.

142 See supra note 135; see also Palmore Oral Argument Notes, supra note 135, at 2 (identifying Justice O'Connor as the source of questioning about adoption concerns at oral argument). All of these Justices can be characterized as race conservatives or race moderates at the time Palmore was decided. Since Bakke, Chief Justice Burger and Justices Rehnquist and Powell had internally expressed the view that all uses of race had to be subjected to strict scrutiny; however, they varied in the time frame during which they first publicly expressed that view, as well as in the extent to which they believed that specific affirmative action programs should accordingly be invalidated. See supra note 67 (documenting the internal circulations in Bakke); see also Wygant v. Jackson Bd. of Educ., 476 U.S. 267, 273-74 (1986) (Powell, joined by Burger and Rehnquist, expressing the view that strict scrutiny was required and that the use of race at issue was invalid); Fullilove v. Klutznick, 448 U.S. 448, 496-99, 523-35 (1980) (Stewart, joined by Rehnquist and Powell, expressing the view that strict scrutiny was required, but dividing on whether the specific program was constitutional); Regents of the Univ. of Cal. v. Bakke, 438 U.S. 265, 291 (1978) (showing that only Powell reached the constitutional issue and would have required strict scrutiny). Justice Stevens had historically opposed affirmative action, but was, at the time, beginning to drift to the 
If the Court's race conservatives were concerned about Palmore's potential implications for adoption, several of its race liberals were concerned about its possible meaning for the ongoing battles over affirmative action. ${ }^{143}$ Despite the apparent victory that the Court's race liberals had achieved in Fullilove v. Klutznick (the Court's then-most recent foray into the affirmative action arena), the 1983 Term marked a tenuous time for affirmative action on the Court. ${ }^{144}$ Ronald Reagan, elected in 1980, had staked out an anti-affirmative action position in his campaign. ${ }^{145}$ And, the October 1983 Term - with the Title VII case of Firefighters Local Union No. 1784 v. Stottsmarked the first major opportunity for the Reagan Administration to articulate its views to the Court. ${ }^{146}$

The Stotts brief, signed by Solicitor General Rex Lee, was true to Reagan's anti-affirmative action platform. ${ }^{147}$ The district court in Stotts had modified a Title VII consent decree (which, as originally written, would have required layoffs to occur in straight seniority order) to avoid reversing

left and would ultimately join the race liberals on the Court. Diane Marie Amann, John Paul Stevens and Equally Impartial Government, 43 U.C. DAVIS L. REV. 885, 887-90 (2010). And Justice White, who had initially embraced intermediate scrutiny in Bakke, was drifting to the right and would soon provide the dispositive vote on the Court for applying strict scrutiny to state and local government affirmative action. See City of Richmond v. J.A. Croson Co., 488 U.S. 469, 493-95 (1989) (showing that Justice White joined the plurality opinion applying strict scrutiny); $i d$. at 520 (Scalia, J., concurring) (providing the fifth vote in Croson for strict scrutiny); Bakke, 438 U.S. at 356 (Brennan, J., concurring) (showing that Justice White joined Justice Brennan's concurrence requiring only intermediate scrutiny). Interestingly, this transition may have marked relatively little change on the personal level, as Justice White apparently felt in Bakke that strict scrutiny was the appropriate standard and acceded to intermediate scrutiny only at Justice Brennan's urging. See supra note 67.

143 See infra notes $161-65$. It is not entirely clear how broadly this concern was shared among the Court's race liberals (and Justice Stevens, then drifting toward the race liberal camp), but it appears that Justices Stevens, Blackmun, and Marshall all may have identified the implications for affirmative action as a potential concern in Palmore.

144 See 448 U.S. at $492-54$ (affirming, in a fractured set of opinions, the constitutionality of a federal set-aside for minority businesses).

145 See Neal Devins, Affirmative Action After Reagan, 68 TEX. L. REV. 353, 354 (1989) (contrasting the affirmative action initiatives instituted during the Carter Administration with Reagan's emphasis on equal opportunity without "inherently discriminatory" requirements).

146467 U.S. 561, 578-83 (1984) (holding that the district court had improperly modified an existing consent decree to require race-based deviations from an otherwise applicable seniority system, despite the fact that the district court action was intended to preserve recent black hiring gains). See generally GiRARDEAU A. SPANN, THE LAW OF AFFIRMATIVE ACTION 10-43 (2000) (surveying the development of the Court's reasoning in affirmative action decisions from the $1950 \mathrm{~s}$ through the 1980s).

147 See infra notes 149-150 and accompanying text (describing the Solicitor General's arguments in favor of the petitioners). 
recent gains in the hiring of black firefighters. ${ }^{148}$ Filing on the side of the white workers, Solicitor General Lee's brief contended that Title VII broadly precluded the district court's action-and the use of race generally to favor minority workers-except where those workers were specifically identified victims of discrimination. ${ }^{149}$ More ominously (from the perspective of the Court's race liberals), the Solicitor General's brief also suggested that the disputed action in Stotts-by benefitting nonvictim minority employees-might violate the Equal Protection component of the Fifth Amendment. ${ }^{150}$

Four months later, this "suggestion" in Stotts would become an explicit argument in the case of Bratton v. City of Detroit. ${ }^{151}$ Bratton involved the City of Detroit's voluntary adoption of racial targets for hiring and promoting black officers on its police force, an effort undertaken after decades of racial discrimination within the Department. ${ }^{152}$ White police officers had challenged the affirmative action program on both statutory and constitutional grounds, contending that the program's explicit use of racial criteria violated Title VII and the Equal Protection Clause. ${ }^{153}$ In December 1983, after losing in the Sixth Circuit, the white officers petitioned for certiorari review by the Supreme Court. 154

In a move widely perceived as a victory for the anti-affirmative action faction within the Reagan Administration, the Solicitor General's office filed a brief supporting the white police officers' request for certiorari review. ${ }^{155}$ Marking the first time that the Administration had argued directly

148 Stotts, 467 U.S. at 565-67. The consent decree had provided for hiring targets of minority workers, but had not disrupted the seniority-based rules for layoffs. The district court modified the consent decree to avoid the possibility that straight seniority layoffs would wipe out the recent hiring gains of minority workers under the consent decree.

149 Brief for the United States as Amicus Curiae Supporting Petitioners at 11-29, Stotts, 467 U.S. 561 (Nos. 82-206, 82-229).

$150 \mathrm{Id}$. at 29-31 ("[T] he court of appeals' holding raises the issue of constitutionality of a race conscious order under the equal protection component of the Due Process Clause of the Fifth Amendment.").

151704 F.2d 878 (6th Cir. 1983), cert. denied, 464 U.S. 1040 (1984), abrogated by Wygant v. Jackson Bd. of Educ., 476 U.S. 267 (1986).

152 Id. at $882,888-90$.

153 Id. at 881 .

154 See id. at 884, 897-98 (rejecting the officers' Title VII and constitutional claims); see also Robert Pear, U.S. Attacks Plan that Sets Quotas for Hiring Blacks, N.Y. TimeS, Dec. 3, 1983, at 1 (describing the government's brief urging Supreme Court review and arguing against the hiring and promotion plan).

155 See, e.g., Pear, supra note 154 ("The filing of the brief indicated that ... [the] Assistant Attorney General for civil rights[] had prevailed within the Administration over people ... who had argued that race-conscious affirmative action plans were legal and constitutional."); see also Robert Pear, Administration Is Hoping to Force Court to Confront Racial Quotas, N.Y. TIMES, Dec. 5, 
to the Court that affirmative action was unconstitutional, the brief contended broadly that voluntary affirmative action plans employing explicit racial criteria violated the Equal Protection Clause. ${ }^{156}$ Moreover, the Administration contended that this was so even in cases such as Bratton, where such affirmative action plans were undertaken in response to "undeniable past discrimination against blacks." 157 The position staked out by the administration in Bratton - that voluntary affirmative action, even where designed to address past racial discrimination by the state itself, was constitutionally impermissible-was thus on the far extremes of the affirmative action debates. ${ }^{158}$

It is perhaps unsurprising, then, that the Reagan Administration's brief in Palmore-filed days after its Bratton brief-was greeted with some suspicion by the Court's race liberals. ${ }^{159}$ On its face, the brief (filed in support of Linda Palmore) appeared to contain little that could arouse the Court's race liberals' ire. The fundamental position the brief expressedthat the lower court's use of interracial marriage to deprive Linda Palmore of custody was constitutionally invalid-was one with which the Court's race liberals (and indeed, ultimately all of its Justices) agreed. ${ }^{160}$ Moreover, nowhere did the brief explicitly suggest that the lower court's actionsrelying on the child's "best interests" to transfer custody away from a white woman-could be considered akin to affirmative action.

But, read in the context of the Administration's mounting campaign against affirmative action, it is not difficult to see how some of the Justices saw the brief in a different, fundamentally less innocuous, light. Read in light of that campaign, the Administration's argument in Palmore that " $[t]$ he Equal Protection Clause does not 'protect' certain racial classes to the exclusion of others; it protects all persons from invidious racial classification" must have appeared to the Justices directed less at the possibility that black parents who married interracially might be subject to the same rules

1983, at $\mathrm{B}_{13}$ (describing the brief as a "translat[ion of] the Administration's political campaign against affirmative action"); Philip Perlmutter, Op-Ed., A New Kind of Discrimination, Bos. GLOBE, Jan. 31, 1984, at A19.

156 See Pear, supra note 154.

157 Id.; see also Bratton, 704 F.2d at 888-90 (affirming a finding of a history of discrimination against black police officers in Detroit).

158 See generally Pear, supra note 154 .

159 Compare id. (dating the filing of the Administration's Bratton brief as Friday, December 2, 1983), with Brief for the United States as Amicus Curiae Supporting Petitioner, Palmore v. Sidoti, 466 U.S. 429 (1984) (No. 82-1734) (filed on Friday, Dec. 9, 1983).

160 Brief for the United States, supra note 159, at 7-9; see also Palmore, 466 U.S. at 434 ("The effects of racial prejudice . . . cannot justify a racial classification removing an infant child from the custody of its natural mother...."). 
and more to the broader question of whether the race of the victim "matters" in equal protection adjudication. ${ }^{161}$ Similarly, the Administration's exhortation that "[a] racial classification, regardless of purported motivation, is presumptively invalid" must have seemed targeted less at the best interest of the child argument in Palmore and more to the wider debates over "benign" motivations in race law. ${ }^{162}$

Thus, while the Court's race liberals (and ultimately all of its Justices) supported the result urged by the Solicitor General in Palmore, a number of them were deeply skeptical of the reasoning proposed in the Administration's amicus brief. Indeed, Justice Stevens-who alone among the Justices appears to have been concerned both about the affirmative action and the adoption implications of Palmore - went so far as to urge that the Justices avoid the potential implications of the Solicitor General's reasoning by eschewing an equal protection rationale altogether. ${ }^{163}$ Instead, Justice Stevens urged that the Court rely on the due process reasoning that the Court had expressed in Stanley v. Illinois, an approach that at least one other Justice, Justice Blackmun, appears to have been prepared to endorse. ${ }^{164}$ While ultimately Stevens's proposal did not obtain significant support among the other Justices, it appears to have been reflective of a broader feeling that the Solicitor General's approach was intended to-and could in fact-bleed into the Court's ongoing affirmative action debates. ${ }^{165}$

161 Brief of the United States, supra note 159, at 9.

162 Id. at 8 (quoting Pers. Adm'r v. Feeney, 442 U.S. 256, 272 (1979)).

163 See Brennan Conference Notes, Palmore v. Sidoti, supra note 135 (noting for Justice Stevens, "I think its [sic] quite appropriate in writing the opinion that we not follow SG approachbetter is BRW's due process approach in Stanley v. Illinois"); Blackmun Conference Notes, Palmore v. Sidoti, supra note 135 (noting for Justice Stevens, "[D]o n[ot] buy SG's broad approach. Stanley v. Ill [illegible] is + way, ie, DP, n[ot] EP”). Interestingly, at least one Justice's notes connect Justice Stevens' preference for Due Process instead to his concerns over adoption. See Powell Conference Notes, Palmore v. Sidoti, supra note 135 (noting for Justice Stevens, "Stanley v. Ill due process rationale is preferred analysis. If we rely on E/P we might prejudge adoption").

164 Id.; see also Harry A. Blackmun, Handwritten Notation on First Draft of Burger Opinion, No. 82-1734, Palmore v. Sidoti (on file with the Library of Congress, Harry A. Blackmun Papers) (Mar. 15, 1984) (noting, "Prefer DP, n[ot] EP Stanley v. Ga?"); Blackmun Conference Notes, Palmore v. Sidoti, supra note 135 (showing a check mark next to Stevens' recorded remarks regarding the preferability of relying on the Stanley v. Illinois approach). See generally Stanley v. Illinois, 405 U.S. 645 (1972) (invalidating a statutory provision that presumed unwed fathers were unfit parents on equal protection and due process grounds).

165 See supra notes 163-64 and accompanying text; see also Bench Memorandum on No. 821734, Palmore v. Sidoti, to Thurgood Marshall 5 n.3 (Feb. 22, 1984) (on file with the Library of Congress, Thurgood Marshall Papers) ("An ulterior motive for the SG's brief seeking to strike down the racially discriminatory ruling of the Florida Court may be the SG's desire to emphasize the point that racial considerations are illicit in all contexts-including the affirmative action context."); $c f$. Brief for the ACLU et al. as Amici Curiae Supporting Petitioner at 9-14, Palmore, 466 U.S. 429 (No. 82-1734) (relying on colorblindness rhetoric and affirmative action precedents 
Ultimately, however, the opinion drafted by Chief Justice Burger in Palmore would not strongly implicate either of these sets of concerns. As Justice Blackmun's law clerk observed, the reasoning of the initial draft was "difficult to get much [of] a handle on." Thus, the Burger draft employed fairly sweeping rhetoric about the racial harm being remedied while couching its holding in terms that had ambiguous salience for other legal contexts. ${ }^{166}$ As a result, none of the Justices apparently felt their previously expressed concerns were sufficiently implicated by Burger's draft to warrant a request for revisions (although one internal notation suggests that those concerns remained at the time the draft was circulated). ${ }^{167}$

Indeed, only Justice Brennan-concerned that the opinion could be read to permit the use of race where it was only a partial (as opposed to dispositive) consideration-raised any dispute at all regarding the reasoning that Chief Justice Burger employed in his initial draft. ${ }^{168}$ And when the Chief Justice responded that a narrow holding was indeed warranted-and made only minor modifications to his draft-even Justice Brennan nevertheless joined. ${ }^{169}$ Thus, the Court's final ruling, issued on April 25, 1984, was

to argue that the use of race in Palmore was invalid, but specifically noting that the use of race in remedial contexts should be treated differently).

166 Memorandum from E.T. on No. 72-1734, Palmore v. Sidoti, to Harry A. Blackmun (Mar. 16, 1984) (on file with the Library of Congress, Harry A. Blackmun Papers); see also First Draft of Burger Opinion, No. 82-1734, Palmore v. Sidoti 5-6 (Mar. 15, 1984) (on file with the Library of Congress, William J. Brennan, Jr., Papers) (stating that the Constitution cannot tolerate prejudice, but offering little guidance on how to apply that principle outside the context of the specific facts of the case).

167 See generally Harry A. Blackmun Papers, Box 402, Folder 11 (showing no mention, in the circulated memoranda on file, of a request by any of the Justices to revise Justice Burger's draft due to affirmative action or adoption concerns); see also Handwritten Notation on First Draft of Burger Opinion, supra note 166 , at 1 (querying internally, "[S]h[oul]d th[ere] b[e] a reservation w[ith] r[espect] t[o] adoption? [P]refer DP, n[ot] EP Stanley v. Ga?").

168 See Memorandum from William J. Brennan, Jr., on No. 82-1734, Palmore v. Sidoti, to Warren E. Burger (Mar. 20, 1984) (on file with the Library of Congress, William J. Brennan, Jr., Papers) (suggesting changes to the opinion that would clarify that race cannot be used as a consideration in any respect in the child custody context, even when such consideration is not dispositive); see also Memorandum from E.T., supra note 166 (noting shortly prior to Brennan's memorandum that "that there is some discussion about encouraging the $\mathrm{CJ}$ to make this opinion stronger-to make clear that race not only cannot be the dispositive factor, but that it is an impermissible consideration in a child custody termination proceeding"); Handwritten Notation on First Draft of Burger Opinion, No. 82-1734, Palmore v. Sidoti 5 (Mar. 15, 1984) (on file with the Library of Congress, William J. Brennan, Jr., Papers) (noting that the passage prohibiting race from being a "dispositive" consideration should be changed to preclude race "in any respect whatever be[ing] a" basis for a denial of custody).

169 See Memorandum from Warren E. Burger on No. 82-1734, Palmore v. Sidoti, to William J. Brennan, Jr. (Mar. 21, 1984) (on file with the Library of Congress, William J. Brennan, Jr., Papers) (explaining the rationale behind a narrow holding); see also Second Draft of Burger Opinion, No. 82-1734, Palmore v. Sidoti 3 (Apr. 19, 1984) (on file with the Library of Congress, 
unanimous in favor of Linda Palmore, bearing no external signs of the internal concerns that the case had initially aroused. ${ }^{170}$

\section{PALMORE TO ADARAND: 1985-1995}

The next ten years-from 1985 to 1995 -would mark a turning point in both affirmative action case law and race family law in the United States. In the affirmative action context, the Court's constitutional standards for reviewing affirmative action-still arguably hospitable to the race liberals' preferred intermediate scrutiny standard at the time that Palmore was decided-would turn first tentatively, and then decisively, toward strict scrutiny review. ${ }^{171}$ Thus, in 1986 the Court would issue a decision in which four of the Justices publicly called for strict scrutiny review (a view that many of the still-serving race conservatives had privately expressed as early as Bakke), with a fifth declining to publicly endorse a standard. ${ }^{172}$ And by mid-1989, the Court had decisively held that all state and local government uses of race must be subjected to strict scrutiny; a holding extended, after initial equivocation, to the federal government in $1995 .{ }^{173}$ Thus the decade between 1985 and 1995 marked a dramatic change in the Court's affirmative action precedents, away from the fractured opinions that characterized the late 1970 s and early 1980 s (opinions at least partially favorable to the position of the Court's race liberals) to a solid majority in favor of applying

William J. Brennan, Jr., Papers) (maintaining the narrow holding from the original draft); Memorandum from William J. Brennan, Jr., on No. 82-1734, Palmore v. Sidoti, to Chief Justice Burger (Apr. 20, 1984) (on file with the Library of Congress, William J. Brennan, Jr., Papers) (agreeing to join the Chief Justice's opinion).

170 Palmore v. Sidoti, 466 U.S. 429 (1984).

171 At the time that Palmore was decided, the Court had decided three significant cases on "benign" uses of race: United Jewish Organizations of Williamsburgh, Inc.(UJO) v. Carey, 430 U.S. 144 (1977); Regents of the University of California v. Bakke, 438 U.S. 265 (1978); and Fullilove v. Klutznick, 448 U.S. 448 (1980). In each of these cases, there was no majority opinion regarding the proper standard of scrutiny to be applied, and a plurality of Justices articulated support for something less than strict scrutiny. See Fullilove, 448 U.S. at 517-21 (Marshall, J., concurring, joined by Justices Brennan and Blackmun); Bakke, 438 U.S. at 324-79 (Brennan, White, Marshall, \&Blackmun, JJ., concurring); UJO, 430 U.S. at 148-65 (plurality opinion).

172 See Wygant v. Jackson Bd. of Educ., 476 U.S. 267, 273-74 (1986) (plurality opinion) (applying strict scrutiny to the use of race in the context of layoff decisions regarding public school teachers); id. at 295 (White, J., concurring).

173 See City of Richmond v. J.A. Croson Co., 488 U.S. 469, 493-98 (1989) (plurality opinion); id. at 520 (Scalia, J., concurring) (making clear that strict scrutiny must be applied to "benign" state and local government uses of race); Adarand Constructors, Inc. v. Pena, 515 U.S. 200, 227 (1995) (applying the same standard to the federal government and overruling in relevant part Metro Broadcasting v. FCC, 497 U.S. 547 (1990)). 
the most stringent standard of constitutional review even to "benign" uses of race.

This turn-perceived at the time as a major upheaval in the Court's race law jurisprudence ${ }^{174}$ - was justified by the Court primarily through two core rhetorical arguments. First, while continuing to facially recognize that certain racial classifications might be justified by compelling circumstances, by the mid-199os the Court spoke far more often in terms of the inherent harms of government uses of race. ${ }^{175}$ Thus, the majority decisions for the Court during this time period began to refer to all racial classificationsincluding those intended to benefit racial minorities-in broadly negative terms, characterizing such classifications as "pernicious," "odious," and "stigmatiz[ing]."176 While continuing to pay lip service to the notion that strict scrutiny was intended to "smoke out" invidious uses of race, the Court in fact turned toward an understanding in which government uses of race may be justified by compelling objectives, but are always fundamentally non-benign. ${ }^{177}$ This rhetorical turn, which would take on an even more strident form in some of the later opinions authored by the Court's race conservatives, provided the Court with its fundamental normative justification for treating affirmative action as constitutionally akin to invidious uses of race. ${ }^{178}$

174 For news articles discussing the significance of Adarand and Croson, see Joan Biskupic, Court's Conservatives Make Presence Felt: Reagan Appointees Lead Move Rightward, WASH. POST, July 2, 1995, at A1 (describing the Court's decision in Adarand and other 1994 Term decisions as "finally deliver[ing]" on Ronald Reagan's anti-affirmative action agenda and "set[ting] in motion a rollback of federal affirmative action programs"); Linda Greenhouse, Court Bars a Plan Set UP to Provide Jobs to Minorities, N.Y. TIMES, Jan. 24, 1989, at A1 (describing how the Croson ruling "cast constitutional doubt on a wide variety of government hiring and contract programs to aid minorities"); David G. Savage, Supreme Court Rulings Herald Rehnquist Era, L.A. TimES, July 2, 1995, at A1 (stating that the Adarand ruling "puts in jeopardy every federal program that explicitly uses race as a criterion for awarding contracts or jobs").

175 See, e.g., Adarand, 515 U.S. at 223-24, 229, 236 (characterizing race-based distinctions as "odious" and "inherently suspect" (citations omitted)); id. at 240-41 (Thomas, J., concurring in part and concurring in judgment) ("[T]here can be no doubt that racial paternalism and its unintended consequences can be as poisonous and pernicious as any other form of discrimination."); Shaw v. Reno, 509 U.S. 630, 643 (1993) ("Classifications of citizens solely on the basis of race 'are by their very nature odious to a free people whose institutions are founded upon the doctrine of equality."” (citations omitted)); Croson, 488 U.S. at 493-94, 500 ("Classifications based on race carry a danger of stigmatic harm."); id. at 521, 527-28 (Scalia, J., concurring) (expressing the view that all racial classifications are inherently malign).

176 Adarand, 515 U.S. at 223-24, 229, 236 (citations omitted); Shaw, 509 U.S. at 643.

177 But see Croson, 488 U.S. at 493 (reiterating that the purpose of strict scrutiny is to "smoke out" invidious uses of race).

178 See supra notes 175-77; see also Parents Involved in Cmty. Sch. v. Seattle Sch. Dist. No. 1 (PICS), 551 U.S. 701, 721, 745-48 (2007) (drawing on Brown to argue that public school policies intended to promote integration were constitutionally impermissible, and characterizing the use of 
The Court buttressed these normative claims of inherent invidiousness with related claims of "consistency" (i.e., claims that the Court must treat all racial classifications the same). ${ }^{179}$ " $[\mathrm{A}] \mathrm{ll}$ racial classifications," the Court increasingly claimed, "must be strictly scrutinized" by the courts. ${ }^{180}$ In other words, racial classifications of any kind "are constitutional only if they are narrowly tailored measures that further compelling governmental interests." 181 Thus, in the late 1980s and 1990s, the Court turned away from the notion of contextual variability toward a claim of global consistency, requiring the most stringent form of scrutiny for all government uses of race. ${ }^{182}$ And although this rhetorical theme emerged primarily as a normative explanation for why the claims of white plaintiffs should be treated the same as the claims of racial minorities, it would ultimately evolve into a broad descriptive claim and doctrinal mandate to which the Court itself would claim adherence. ${ }^{183}$

Both of these core justifications for the Court's increasingly stringent review of affirmative action programs-inherent invidiousness and cross-contextual consistency-arguably should have had profound implications for the use of race in family law. For although, in the aftermath of Palmore, the lower courts did largely cease to award custody modifications based on interracial marriages; ${ }^{184}$ they typically construed Palmore as having relatively little importance for other ongoing uses of race. ${ }^{185}$

racial classifications as "odious," "promot[ing] 'notions of racial inferiority," "contributing to an escalation of racial hostility and conflict," and "demean[ing to] the dignity and worth of a person" (citations omitted)); id. at 751-52, 758, 778-82 (Thomas, J., concurring) (comparing the dissent's arguments in favor of the consideration of race as a means of promoting integration to the segregationist states' arguments in Brown and to the "elite[]" racial theories at issue in Dred Scott and Plessy); Grutter v. Bollinger, 539 U.S. 306, 349, 353 (2003) (Thomas, J., concurring in part and dissenting in part) ("[E]very time the government places citizens on racial registers and makes race relevant to the provision of burdens or benefits, it demeans us all.").

179 See, e.g., Adarand, 515 U.S. at 224; see also Shaw, 509 U.S. at 643.

180 Adarand, 515 U.S. at 224 (emphasis added).

$181 \mathrm{Id}$. at 227.

182 See id. at 224, 227; see also Shaw, 509 U.S. at 643.

183 See Adarand, 515 U.S. at 224, 227; see also Fisher v. Univ. of Tex. at Austin, 133 S. Ct. 2411, 2417-19 (2013); PICS, 551 U.S. at 720, 739 n.16, 741-42; id. at 751-52, 758-59, 778-82 (Thomas, J., concurring); Gratz, 539 U.S. at 270.

184 See, e.g., Turman v. Boleman, 510 S.E.2d 532 (Ga. Ct. App. 1998) (holding a child custody decree that prohibited the child's contact with African American males void, and barring the husband from withholding visitation to the mother based on her marriage to an African American man); Holt v. Chenault, 722 S.W.2d 897 (Ky. 1987) (holding that the impact of a mother's subsequent biracial marriage is an inappropriate basis for custody modification); Elliott v. Boyes, 13 Phila. 273, 283, 283 n.5 (Phil. Cnty. Ct. 1985) (finding stepfather's race irrelevant where there was no evidence that his race had adversely affected the children); see also KENNEDY, supra note 7 , at 385-86. But cf. Dansby v. Dansby, ${ }^{189}$ S.W.3d 473 (Ark Ct. App. 2004) (disapproving of the trial 
As a result, Palmore did not eradicate the continuing use of race in adoption and foster care, nor in custody disputes between interracial parents. Instead, the continued use of race in those contexts was largely deemed acceptable by the courts, except where the facts evidenced an exclusive reliance on racial criteria (a limitation with which only the most unsophisticated government actor would be unable to demonstrate compliance). Indeed, courts addressing post-Palmore, race-based family law practices typically found them to be categorically constitutional (i.e., requiring no constitutional scrutiny of any kind) where race was not the exclusive factor considered as part of the best interest of the child assessment.

This approach, while perhaps consistent with a narrow reading of Palmore, was in obvious tension with the Court's post-Palmore affirmative action

court's reliance on the race of the mother's partner in awarding change of custody, but nevertheless affirming on other grounds).

185 See, e.g., J.H.H. v. O'Hara, 878 F.2d 240 (8th Cir. 1989), cert. denied, 493 U.S. 1072 (1990) (declining to read Palmore as a broad proscription against the consideration of race in matters of child custody and foster care placement); Tallman v. Tabor, 859 F. Supp. 1078 (E.D. Mich. 1994) (holding that "[i]t appears well-settled in the case law" that race can be a factor in child placement so long as it is not the only factor); In re Petition of D.I.S., 494 A.2d 1316 (D.C. 1985) (declining to intrude "into the trial court's exercise of discretion in inter-racial adoption cases" because in such cases, "there is no need to reach the constitutional issue of equal protection"); Gloria G. v. State Dep't of Soc. \& Rehab. Servs., 833 P.2d 979 (Kan. 1992) (finding that race could be used as a factor in adoption decisions so long as it is not the sole factor); In re Adoption/Guardianship No. 2633, 646 A.2d 1036, 1047-49 (Md. Ct. Spec. App. 1994) (finding that the use of race as a factor was constitutionally permissible, but that exclusive reliance on race was not; but also finding no error in rejecting prospective adoptive parents' claims, despite lower court finding that race was the "sole criterion"); Carlson v. County of Hennepin, 428 N.W.2d 453, 455, $45^{8}$ (Minn. Ct. App. 1988), cert. denied, 490 U.S. 1023 (1989) (holding that qualified immunity barred a claim in a case where a white couple was told that it was "against county policy to allow a white couple to adopt a black child"); Petition for Writ of Certiorari at app. 27a-28a, In re Welfare of D.L., 486 N.W.2d 375 (Minn. 1992), cert. denied, 506 U.S. 1000 (1992) (No. 92-616) (reproducing lower court decision, which had concluded that Minnesota's race-matching statute was "likely not subject to . . strict scrutiny" "[s]ince it addresses substantial problems arising out of the realities that Minnesota is more than $90 \%$ white" and was designed to "ensure the best interests of children are met by requiring due consideration of the child's minority race"); Memorandum from J.B. on No. 90-123CSX, Wilson v. Darrow, to the Cert Pool 1-4 (Aug. 10, 1990) (on file with the Blackmun Digital Archive) (noting, in a certiorari memorandum describing the lower courts' decisions, that the lower courts had found that although exclusive reliance on race was impermissible, race as a factor was constitutional, and that this was consistent with the consensus of the courts of appeals). But cf. McLaughlin v. Pernsley, 693 F. Supp. 318 (E.D. Pa. 1988) (granting a preliminary injunction and finding that the removal of a foster child violates equal protection where race was the sole basis for the removal), aff'd on other grounds, 876 F.2d 308 (3d Cir. 1989); In re Marriage of Brown, 480 N.E.2d 246, 247-48 (Ind. Ct. App. 1985) (rejecting the notion that race could be a factor in a custody dispute based on Palmore); In re Moorehead, 600 N.E.2d 778 (Ohio Ct. App. 1991) (requiring strict scrutiny where race was the sole factor in adoption determination). See generally Jim Chen, Unloving, 80 IOWA L. REV. 145, 169-70 (1994) (observing, similarly, that Palmore did not eradicate the use of race in family law). 
doctrine. ${ }^{186}$ Both of the Court's key justifications for its new affirmative action doctrine - the inherent invidiousness of all uses of race and the need for consistency across all race-based decisionmaking contexts-facially demanded the application of strict scrutiny to all government uses of race, ${ }^{187}$ even where race was not the exclusive consideration. ${ }^{188}$ And indeed, many of the race-based family law decisions that courts confronted during this time gave, either formally or de facto, at least as much weight to racial considerations as the affirmative action policies that the Court had found to require strict scrutiny (with predictable results for their constitutional validity). ${ }^{189}$

Thus, the Court's affirmative action precedents during this time frame should have profoundly unsettled the lower courts' approach to the remaining instantiations of race in family law (adoption, foster care, and interracial parent custody disputes). But while 1985 to 1995 was a time of considerable change for race in family law doctrine (like affirmative action), this change was not in the direction one would expect. Between 1985 and 1995, rather than moving toward a consensus against the use of race in family law, the lower courts increasingly expressed a consensus that remaining uses of race

186 As discussed, Palmore was written narrowly by Chief Justice Burger precisely to leave open the possibility of using race as a factor in future family law cases. See supra notes 135, 168-69 and accompanying text.

187 All of these race-based family law cases involved state action, as defined for Fourteenth Amendment purposes, in the form of race-based action by a state agency, race-based adjudication, or a state statute mandating the application of race-based criteria. I am aware of no case in which the absence of state action was the basis for rejecting the litigant's equal protection arguments.

188 The view that even using race as a factor requires strict scrutiny was articulated in the affirmative action context by a number of the Court's race conservatives as early as Bakke (in internal memoranda) and was ultimately codified explicitly by the Court in its affirmative action case law. See, e.g., Memorandum from William H. Rehnquist on No. 76-811, Regents of the Univ. of Cal. v. Bakke, to the Conference 1-4 (Jan. 3, 1978) (on file with the Library of Congress, Harry A. Blackmun Papers) (expressing the view in that in the affirmative action context, even use of race as a factor demanded strict scrutiny); see also Grutter, 539 U.S. at 326 (affirming strict scrutiny as the appropriate standard for a case involving a "race as a factor" admissions process); $c f$. Mt. Healthy City Sch. Dist. Bd. of Educ. v. Doyle, 429 U.S. 274, 285-87 (1977) (recognizing that, even where an unconstitutional consideration is merely one factor, it is constitutionally problematic if it is the dispositive factor).

189 Compare J.H.H., 878 F.2d at 242-43 (affirming the dismissal of claims relating to the removal of African American children from a foster home pursuant to a policy requiring placement of minority children with families of "similar racial and ethnic characteristics") and Reisman v. Tenn. Dep't of Human Servs., 843 F. Supp. 356, 365 (W.D. Tenn. 1993) (addressing the issue of race-matching in foster care and adoption and ordering categorically that "bi-racial children shall be placed in foster homes and in adoptive homes with bi-racial families, if possible"), with Adarand, 515 U.S. at 205-09, 235-37 (applying strict scrutiny to a program in which race was one factor, but not the only consideration) and Wygant v. Jackson Bd. Of Educ., 476 U.S. 267, 270-73, 283-84 (1986) (invalidating a layoff policy in which race and seniority were both considerations with four Justices endorsing the application of strict scrutiny). 
in the family were constitutionally permissible. ${ }^{190}$ And while the courts were never completely unified, either in outcome or in approach, by the 1990s, most courts were expressing the view that only de minimis (if any) constitutional scrutiny was demanded of race-based family law practices, at least where race was not the exclusive consideration. ${ }^{191}$ As such, the decade between 1985 and 1995-unlike the preceding decade-was marked by increasing consistency in both the outcome and the reasoning of the courts' approaches to government uses of race in the family; but in ways that diverged profoundly from both the framework adopted (strict scrutiny) and the usual results (invalidation) in the affirmative action context during the same time frame.

Five of the disputes arising during this time frame-all involving racebased adoption or foster care determinations-prompted the litigants involved to seek Supreme Court intervention in these continuing race-based family law practices. First in 1988 and then again in 1989, 1990, 1992, and 1994, disappointed would-be parents petitioned the Court to address state policies and practices that had resulted in the removal of African American

190 See, e.g., J.H.H., 878 F.2d 240; Tallman v. Tabor, 859 F. Supp. 1078 (E.D. Mich. 1994); DeWees v. Stevenson, 779 F. Supp. 25 (E.D. Pa. 1991); In re Petition of D.I.S., 494 A.2d 1316 (D.C. 1985); Gloria G., 833 P.2d 979; Wilson v. Darrow (Ky. Ct. App. 1989), cert. denied, 498 U.S. 851 (1990); In re Adoption/Guardianship No. 2633, 646 A.2d 1036 (Md. Ct. Spec. App. 1994); In re Welfare of D.L., 486 N.W.2d 375 (Minn. 1992), cert. denied, 506 U.S. 1000 (1992); Carlson v. County of Hennepin, 428 N.W.2d 453 (Minn. Ct. App. 1988); cf. Reisman, 843 F. Supp. at 363-66 (finding a violation of equal protection where an agency race-matched biracial children with black parents, but ordering instead that "bi-racial children shall be placed in foster homes and in adoptive homes with bi-racial families"-i.e., that they should be even more specifically racematched); Child v. Stangler, No. 92-0850, 1992 U.S. Dist. LEXIS 19954, at *7-8 (W.D. Mo. Dec. 28,1992 ) (stating that it is "by no means clear" that race-matching in adoption is constitutionally impermissible, but basing holding on abstention grounds); Lee v. Halayko, 590 N.Y.S.2d 647 (App. Div. 1992) (stating that the use of race in custody disputes between interracial parents is generally appropriate, but finding that here it did not tip the balance in favor of the minority parent); In re Moorehead, 600 N.E.2d 778 (Ohio Ct. App. 1991) (disapproving the use of race as a sole consideration in adoption, but approving its use generally). See generally Rhonda Hillbery, "Baby D" Foster Parents in Court Again-Judge Reverses Decision to Allow Adoption of Black Child, STAR TRIB., Sept. 6, 1994, at 1A (describing an adoption case in which the judge reversed a prior decision granting a private adoption based on a state race-matching statute).

191 See, e.g., Tallman, 859 F. Supp. at 1085-88; In re D.I.S., 494 A.2d at 1326-27; Wilson (Ky. Ct. App. 1989); In re D.L., 486 N.W.3d at 375; cf. DeWees, 779 F. Supp. at 26-29 (approving racematching based on common-sense norms, but nominally applying strict scrutiny); McLaughlin v. Pernsley, 693 F. Supp. 318, 323-24 (E.D. Pa. 1988) (applying rigorous constitutional scrutiny where race was the sole factor considered), aff'd on other grounds, 876 F.2d 308 (3d Cir. 1989); In re Moorehead, 600 N.E.2d at 785-88 (same). But cf. In re Marriage of Brown, 480 N.E.2d 246, 247-48 (Ind. Ct. App. 1985) (applying meaningful constitutional scrutiny to an interracial child custody dispute, even though race was not the sole consideration). 
or biracial children from their homes. ${ }^{192}$ Arguing that the courts below had carved out an exception for state-sponsored "segregation" in the family, the litigants in each case contended that the lower courts had lost touch with the Court's broader race law jurisprudence. ${ }^{193}$ Often drawing explicitly on the Court's affirmative action precedents, they called upon the Court to remedy the lower courts' aberrational approach and to strike down the continuing use of race in the adoption and foster care contexts. ${ }^{194}$

But the Court showed no more interest in taking up the issues of adoption or foster care during the 1985 to 1995 time frame than it had at the time that Palmore was decided. While the record of the Justices' personal views of the cases that came up to the Court during this time is sparse, none of the five cases appears to have been perceived as a serious candidate for review. Indeed, in most of the cases for which internal Court records are available,

192 See Petition for Writ of Certiorari at 4-8, J.H.H. v. O'Hara, 493 U.S. 1072 (1990) (No. 89906) [hereinafter J.H.H. Petition] (arguing that review should be granted of a race-based fostercare determination due to its inconsistency with the Courts' race law precedents); Petition for Writ of Certiorari at *11-13, Wilson v. Darrow, 498 U.S. 851 (1990) (No. 90-123) [hereinafter Wilson Petition] (arguing that the defendant's "automatic, race-based exclusion of prospective adoptive parents" lacked the "extraordinary justification" required by the Court's race law precedents); Petition for Writ of Certiorari at *i, Mauk v. Engle, 516 U.S. 809 (1995) (No. 94-1876) [hereinafter Mauk Petition] (asserting that race-based removal of an African American foster child from the care of white foster parents violated the Equal Protection Clause); Petition for Writ of Certiorari at *13-17, Sharp v. Hennepin County, 506 U.S. 1000 (1992) (No. 92-616) [hereinafter Sharp Petition] (arguing that review should be granted to "reaffirm the Constitutional proscription against racial segregation" in the context of race-matching in adoption); see also Memorandum from M.S. on No. 88-6265-CSX, Carlson v. County of Hennepin, to the Cert Pool at 9-10 (1989) [hereinafter Carlson Memo] (on file with the Blackmun Digital Archive) (describing the Carlson Petition, which sought certiorari review of an adoption decision based on Minnesota's racematching statute).

193 J.H.H. Petition, supra note 192, at 4-5; Wilson Petition, supra note 192, at 11-15; Sharp Petition, supra note 192, at 10, 13-18 (describing the County defendant as having encouraged "racial segregation" in removing a black foster child pursuant to Minnesota Minority Heritage Child Protection Act); Mauk Petition, supra note 192, at 12-24; see also Carlson Memo, supra note 192, at 910.

194 See, e.g., Mauk Petition, supra note 192, at 12-24 (drawing, inter alia, on affirmative action case law to call for the Court to intervene and address the lower courts' approach to race family law issues); Sharp Petition, supra note 192, at 13-18 (arguing that the Court should take up the issue of race-matching in adoption since the "race-based decisionmaking of the courts throughout the country is in conflict with this Court's fundamental rulings"); J.H.H. Petition, supra note 192, at 45 (arguing that the Court should grant certiorari to "lay to rest the sinister suggestion raised in this case that state sponsored racial segregation may somehow be countenanced in a democratic society"); Wilson Petition, supra note 192, at 11-15 (drawing on affirmative action case law in arguing that the Court should intervene and address the issue of race-matching in adoption); see also Brief of Respondent in Support of Petition at 6-16, J.H.H., 493 U.S. 1072 (No. 89-906) (same); Carlson Memo, supra note 192, at 9-10 (summarizing the Petitioners' arguments that Carlson County "practices impermissible racial discrimination... that the state c[ou]rts have condoned this practice[,] ... and that it will continue unless this C[our]t acts by granting this pet[itio]n"). 
those records suggest that the case at issue never even made it to the Justices' so-called "discuss list," signifying that not a single Justice thought discussion of the case was warranted as a potential matter for the Court to take up. ${ }^{195}$ And while several of the cases arguably had procedural complications that made them unappealing candidates for certiorari, at least one was, in the words of Justice Blackmun's law clerk, "extraordinary," involving a lower court decision that had denied the plaintiffs the opportunity to demonstrate that even the sole use of race to deny a foster care placement violated their clearly established constitutional rights. ${ }^{196}$ Nevertheless, even this "extraordinary" case appears not to have attracted any serious attention, and ultimately each of the cases would be denied certiorari review.

\section{ADARAND TO GAMBLA: 1996-2007}

While the Court thus declined during the post-Palmore period to become involved in the ongoing constitutional disputes over the propriety of the use of race in adoption and foster care, statutory changes in the mid1990 s would ultimately limit the practical significance of this inaction. In 1994, Congress enacted (and shortly thereafter amended) the Howard M. Metzenbaum Multiethnic Placement Act of 1994 (MEPA). ${ }^{197}$ In its final form (adopted in 1996), MEPA precluded the use of race as a basis for "delay[ing]" or "deny[ing]" foster care or adoption placements by most state

195 See Docket Sheet, No. 92-616, Sharp v. Hennepin County (on file with the Library of Congress, Harry A. Blackmun Papers) (showing no individual vote on Sharp); Docket Sheet, No. 90-123, Wilson v. Darrow (on file with the Blackmun Digital Archive) (showing no individual vote on Wilson); Docket Sheet, No. 89-906, J.H.H. v. O'Hara (on file with the Library of Congress, Thurgood Marshall Papers) (showing no individual vote on J.H.H.); Docket Sheet, No. 88-6265, Carlson v. County of Hennepin (on file with the Blackmun Digital Archive) (showing no votes in favor of granting certiorari in Carlson). See generally Songying Fang, Timothy R. Johnson \& Jason M. Roberts, The Will of the Minority: The Rule of Four on the United States Supreme Court 18 (Oct. 29, 2008) (unpublished manuscript), available at http://www.owlnet.rice.edu/ $\mathrm{sf}_{5} / \mathrm{Fang} /$ Assistant_Professor_files/rule4_fao7_fang.pdf (noting that only those cases that are on the discuss list are voted on at conference).

196 Annotation of M.S. on Memorandum from S.C., Law Clerk, on No. 89-906-CFX, J.H.H. v. O'Hara, to the Cert Pool 8 (Jan. 25, 1990) (on file with the Library of Congress, Harry A. Blackmun Papers); see also J.H.H., 878 F.2d at 243 (noting that the determination in J.H.H. was made pursuant to a policy that " $[\mathrm{m}]$ inority children shall be placed with families of similar racial and ethnic characteristics").

197 Pub. L. 103-382 (codified at 42 U.S.C. $§ 5115 a$ (1994)) (prior to 1996 amendment); see also Solangel Maldonado, Race, Culture, and Adoption: Lessons from Mississippi Band of Choctaw Indians v. Holyfield, 17 COLUM. J. GENDER \& L. 1, 32-34 (2008) (discussing the history behind MEPA). 
actors, thus achieving by statute much of what litigants had long sought (unsuccessfully) to institutionalize as a matter of constitutional law. ${ }^{198}$

Federal enforcement efforts were reportedly weak, and noncompliance rampant, in the initial time frame after MEPA's enactment. But by the mid-to-late 2000s, it appears that MEPA had wrought real, albeit not universal, changes in state adoption and foster care practices. ${ }^{199}$ Indeed, a number of states that had statutes explicitly requiring race-matching in adoption or foster care modified their statutory law following MEPA to, at least ostensibly, preclude such practices. ${ }^{200}$ As a result, by the mid-200os it had become significantly more rare for public institutions (and courts) to rely explicitly on race in adoption or foster care determinations, a decline that is reflected in the case law. ${ }^{201}$

198 Maldonado, supra note 197, at 32-34; see also 42 U.S.C. $\S 671(a)(18)$ (2006 \& Supp. V 2012); 42 U.S.C. § 1996b(1) (1996). Section 671(a)(18) explicitly applies only to those states and entities receiving federal funds. Section $1996 \mathrm{~b}(1)$ is written in ostensibly categorical terms, but provides for enforcement only via Title VI, a spending clause statute. Since the overwhelming majority of state agencies receive federal funding, see Katie Eyer, Rehabilitation Act Redux, 23 YALE L. \& POL'Y REV. 271, 282-87 (2005), MEPA's restrictions thus extend, at a minimum, to the vast majority of public agencies, as well as to those private agencies receiving federal funds.

199 See, e.g., Elizabeth Bartholet, Correspondence, Private Race Preferences in Family Formation, 107 YALE L.J. 2351, 2353-54 (1998) (noting that as of 1998, MEPA had had little effect due to deeply entrenched professional preferences for race-matching and weak enforcement); Meyer, supra note 11, at 195-207 (describing the Department of Health and Human Services' new aggressive enforcement approach to MEPA).

200 Compare MinN. STAT. ANN. § 259.29 (1991) (requiring placement agencies to place minority children in same-race placements, except where a placement with a relative was available), with MINN. STAT. ANN. $\S \S 259.57,260$ C.212 (2007) (collectively prohibiting the state from "delay[ing]" or "deny[ing]" foster care or adoption placements based on race).

201 The effects of MEPA can be seen both in the number and the substance of cases brought in the post-1995 period. Numerically, adoption cases have become much less common in the case law, particularly since the mid-200os. Substantively, post-MEPA adoption cases increasingly involve the refusal of courts or agencies to afford greater weight to race, a claim that is often rejected on the basis of MEPA or its state law analogs. See, e.g., In re Malik S., 1999 Conn. Super. LEXIS 1178, at *16-17 n.5 (May 5, 1999) (recognizing the difficulties "in growing up as a child of mixed race living with white parents" but approving the placement on the basis of MEPA and the child's best interests); In re F.W., 870 A.2d 82, 86-87 (D.C. 2005) ("We disagree . . . with . . . [the] contention[] that the trial court failed to weigh adequately the issues of race, culture, and gender in reaching its determination."); In re P.S., 797 A.2d 1219, 1225 (D.C. 2001) (concluding that "race is simply a factor that may be considered ... in the process of determining the best interests of the child" and that the trial court did not abuse its discretion in refusing to give more weight to the child's race); In re D.T., No. A10-35, 2010 Minn. App. Unpub. LEXIS 682, at *8-9 (July 13, 2010) (rejecting a challenge to the child's placement based on religious and cultural needs); In re D.C., No. A-1151-05T4, 2006 N.J. Super. Unpub. LEXIS 2620, at *6-7 (Apr. 25, 2006) (rejecting the argument that the child should be placed with a relative that would foster ethnic, racial, or cultural identity and noting that "the race of the foster/adoptive parents is not and cannot be a disqualifying factor" under MEPA); In re Maximus H., No. B-07428-07, 2009 N.Y. LEXIS 3371, *3-5 (Fam. Ct. Dec. 10, 2009) (considering matters of racial and cultural identity but refusing to remove the 
MEPA's changes, however, were explicitly limited to the adoption and foster care context and did not reach the courts' continued use of race in custody disputes between interracial parents. Such custody disputes-while always less common than adoption disputes-had traditionally employed very similar reasoning to that used in the adoption and foster care context. ${ }^{202}$ Thus, the courts had typically permitted the use of race as a dispositive factor in interracial custody disputes (on the grounds that the minority parent would be better situated to meet a biracial child's emotional needs), most often without any meaningful constitutional scrutiny. ${ }^{203}$ Indeed, such courts, like courts faced with racial practices in the adoption and foster care context, often held that where race was not the exclusive consideration in the best interest analysis, no constitutional scrutiny was required at all. That reasoning - untouched by MEPA's statutory changes - continued to evolve little in the post-MEPA period, as most courts continued to affirm the propriety of weighing race as a factor in interracial custody disputes. ${ }^{204}$

child from a foster family of another race and religion). But see Ralph Richard Banks, The Multiethnic Placement Act and the Troubling Persistence of Race Matching, 38 CAP. U. L. REV. 271, 284-85 (2009) (arguing that some agencies have simply moved to a regime of thinly veiled racematching, often under the rubric of "cultural competency"). Since MEPA was amended in 1996, only two courts have addressed the constitutionality of relying on race in adoptive or foster care placements, with opposite results. Compare In re Andrea Lynn Carpenter, No. 217634, 1999 Mich. App. LEXIS 2140, at *8-10 \& n.3 (Dec. 3, 1999) (finding the trial court's reliance on race was constitutionally unproblematic where race was not the sole consideration), with Kenny A. v. Perdue, No. 02-1686, 2004 U.S. Dist. LEXIS 27025, at *21-22 (N.D. Ga. Dec. 11, 2004) (allowing a claim of unconstitutional racial discrimination, in a case where the circumstantial evidence supported the conclusion that the agency had a virtually categorical policy of race-matching, to survive summary judgment); cf. In re A.B., 663 N.W.2d 625, 634-36 (N.D. 2003) (rejecting an equal protection challenge to the application of the ICWA to the adoption of Indian children), cert. denied, 541 U.S. 972 (2004).

202 See infra note 203.

203 See, e.g., Raysor v. Gabbey, 395 N.Y.S.2d 290, 294-95 (App. Div. 1997) (holding that racial considerations "should be a matter of first importance in weighing the child's best interests" in a custody dispute between an African American father and white grandparents); Ward v. Ward, 216 P.2d 755, 756 (Wash. 1950) ("These ... victims of a mixed marriage ... will have a much better opportunity to take their rightful place in society if they are brought up among their own people."). But see Lee v. Halayko, 590 N.Y.S.2d 647, 648 (App. Div. 1992) (upholding the trial court's decision to place partially Chinese children with the non-Chinese parent on the grounds that the non-Chinese parent was sufficiently culturally competent); Farmer v. Farmer, 109 Misc. 2 d 137, 146-47 (N.Y. Sup. Ct. 1981) (surveying the case law and concluding that race should be weighed as a factor but not a "dominant" or "controlling" one); Tucker v. Tucker, 542 P.2d 789 (Wash. Ct. App. 1975) (questioning the validity of Ward but nevertheless affirming that race can be a factor in custody disputes between interracial parents). Only two cases have ever invalidated the use of race in the interracial custody context on constitutional grounds. See In re Marriage of Brown, 480 N.E.2d 246 (Ind. Ct. App. 1985); Beazley v. Davis, 545 P.2d 206, 207-08 (Nev. 1976).

204 See, e.g., Gambla v. Woodson, 853 N.E.2d 847, 868-70 (Ill. App. Ct. 2006) ("[S]o long as race is not the sole consideration for custody decisions, but only one of several factors, it is not an unconstitutional consideration."); Ebirim v. Ebirim, 620 N.W.2d 117, 122 (Neb. Ct. App. 2000) 
Thus, while racial factors were not always deemed dispositive in the circumstances of a particular case, courts called upon to adjudicate interracial custody disputes during this time frame continued to regularly reaffirm the legal validity of the use of race to determine a child's best interests in interracial custody disputes.

Exemplary of this continuing practice and the constitutional disputes that it continued to engender, was the Illinois case of Gambla v. Woodson. ${ }^{205}$ Filed in 2003 in Illinois Circuit Court, Gambla v. Woodson was the product of a brief and unhappy marriage between Christopher Gambla, a white man, and Kimberly Woodson, an African American woman. ${ }^{206}$ At primary issue in Gambla and Woodson's divorce was custody of their one child-a biracial baby daughter named Kira-for whom they both claimed to be the primary caregiver. ${ }^{207}$ At trial, Gambla and Woodson would each introduce an abundance of evidence in support of their custody claims, with four experts and ten lay witnesses testifying over the course of the seventeen-day trial. ${ }^{208}$ Race played an important role in the trial, with Woodson introducing expert testimony that Kira-as a biracial child-would be better served by an award of custody to her African American mother. ${ }^{209}$

Despite this evidence-and the fact that many courts in similar circumstances had awarded custody to the minority parent-Christopher had reason to be optimistic that race would not play a meaningful role in the determination of Kira's custody. Historically, Illinois had not been a solicitous jurisdiction for race-based family law decisionmaking, frequently abandoning or limiting race-based family law rules long before other jurisdictions did. ${ }^{210}$ Indeed, the Illinois Court of Appeals was the first court in the country to invalidate a trial court's race-based award of custody in a dispute between interracial parents, finding in 1956 that an automatic

("consider[ing] the impact of [the child's] biracial heritage in light of all the relevant factors"); Savage v. Cota, 885 N.Y.S.2d 798, 799 (N.Y. App. Div. 2009) ("We reject the . . contention that the court relied too heavily on the child's race in determining . . . custody."); In re Davis, 658 N.Y.S.2d 548, 550 (App. Div. 1997) (making clear that race can be considered as a factor, but finding it was not dispositive in the case under review); Olivier A. v. Christina A., No. 3077912002 (Sup. Ct. Aug. 2005) (considering race as a factor, but finding it nondispositive).

205 Gambla, 853 N.E.2d 847.

206 Id. at 849.

207 Petition for Writ of Certiorari at app. 63a, 130a-32a, Gambla v. Woodson, 552 U.S. 1056 (2007) (No. 06-1193) (trial court opinion and expert report of Daniel J. Hynan, Ph.D.).

208 Id. at app. 63 a (trial court opinion).

$209 I d$. at app. 68a.

210 See infra notes 211-12. Illinois also repealed its antimiscegenation law in 1874, long before most other states had done so. Lynn D. Wardle \& Lincoln C. Oliphant, In Praise of Loving: Reflections on the "Loving Analogy" for Same-Sex Marriage, 51 HOW. L.J. 117, 180 app. III (2007). 
race-based award to the minority parent was impermissible. ${ }^{211}$ And while the Illinois courts had not, in the years since, issued a published decision addressing the use of race to determine custody between interracial parents, they had, in other contexts, repeatedly rejected lower court attempts to inject race into family law decisionmaking. ${ }^{212}$ Thus, while Illinois law arguably allowed the use of race as a factor in custody disputes (so long as it was not dispositive), in practice, custody decisions resting on racial grounds were rarely upheld. ${ }^{213}$

Moreover, in Kira's case, it seemed that all factors other than race pointed toward an award of custody to Christopher. ${ }^{214}$ Both of the custody experts who had evaluated the family, including Kimberly's own, voiced strong opinions at trial that custody should be awarded to Christopher. ${ }^{215}$ Relying in part on psychological testing and in part on Kimberly's history of physical aggression in intimate relationships, both expressed concerns that

211 Fountaine v. Fountaine, 133 N.E.2d 532, 533-35 (Ill. App. Ct. 1956). For a case illustrative of other courts' approaches to this issue during the same time frame, see, for example, Ward v. Ward, 216 P.2d 755, 756 (Wash. 1950), which held that biracial children should be raised by their African American grandmother, rather than their white mother because "[ $t]$ hey will have a much better opportunity to take their rightful place in society if they are brought up among their own people."

212 See, e.g., Langin v. Langin, 276 N.E.2d 822 (Ill. App. Ct. 1971) (reversing the trial court's custody decision for relying too heavily on the factor of race); Stingley v. Wesch, 222 N.E.2d 505, 507 (Ill. App. Ct. 1966) (finding that race should not be decisive in a custody dispute and that the stepfather's race had no significance in the proceeding).

213 But see Russell v. Russell, 399 N.E.2d 212 (Ill. App. Ct. 1979) (affirming the decision of a trial court that had relied in part on the possibility of social stigmitazation as a result of the mother's interracial marriage, because its partial reliance did not overweigh other considerations and was not decisive).

214 Aside from race, the factors that the trial court explicitly referenced were all found to either be equal, or weigh in favor of Christopher. From a practical perspective, however, it is certainly possible that Christopher's sex (i.e., status as a father), also played a role, albeit a silent one in the court's decisionmaking. See, e.g., Solangel Maldonado, Beyond Economic Fatherhood: Encouraging Divorced Fathers to Parent, 153 U. PA. L. REV. 921, 967-75 (2005) (discussing the possibility that fathers continue to be disadvantaged by informal social norms in custody disputes despite the abolition of the tender years doctrine, but concluding that the evidence is mixed); Steven N. Peskind, Determining the Undeterminable: The Best Interest of the Child Standard as an Imperfect But Necessary Guidepost to Determine Child Custody, 25 N. ILL. U. L. REV. 449, 465 \& nn. $73 \& 74(2005)$ (noting that Illinois abolished its tender years doctrine as a violation of its state Equal Rights Amendment in the 1970s).

215 See Gambla, 853 N.E.2d at 851-54, 860-61 (outlining the evaluators' reasons for recommending that Christopher receive custody); Petition for Writ of Certiorari, supra note 207, at app. 126a-64a (expert reports of Daniel J. Hynan, Ph.D., and Robert P. Hatcher, Ph.D.); see also Gambla, 853 N.E.2d at 872 (Byrne, J., concurring) (noting that Woodson selected one of the two experts who testified that custody should be awarded to Gambla). 
Kimberly suffered from impulsivity and self-control problems. ${ }^{216}$ Both experts also suggested that Kimberly-who embraced alternative medicine approaches without scientific support and who had arguably ignored the seriousness of her older son's mental health problems-appeared to lack judgment when it came to her children's medical care. ${ }^{217}$ Finally, the experts noted that Christopher was more likely to encourage continued contact with the noncustodial parent, an important consideration under Illinois custody law. ${ }^{218}$ Thus, while noting that Kimberly was also a loving and competent parent, both of the formal custody evaluators recommended an award of custody to Christopher. ${ }^{219}$

In contrast, neither of the two experts introduced by Kimberly at trial had met with Kira or Christopher (and indeed in one instance had not met with Kimberly herself) and neither had been approved as a custody expert by the court. 220 Thus, both of Kimberly's experts restricted their testimony primarily to critiquing certain methodological defects in the reports of the two formal custody evaluators. ${ }^{221}$ Specifically, both of Kimberly's experts questioned the inferences that the Drs. Hynan and Hatcher had drawn from Kimberly's psychological testing, contending that those inferences were culturally biased and lacked context. ${ }^{222}$ Finally, despite not being qualified to do so, both of Kimberly's experts testified that because Kira was biracial, she would be best served by being placed with Kimberly, the minority parent. ${ }^{223}$ As described by the trial court, both experts "seemed to be testifying for the proposition that solely because [Kimberly] is African

216 Petition for Writ of Certiorari, supra note 207, at app. 134a, 136a, 146a, 155a (reproducing Dr. Hynan's and Dr. Hatcher's reports, and reflecting that both expressed concerns about Kimberly's impulsivity and self-control in view of the testing profile observed by Dr. Hynan).

$217 I d$. at app. 145a-146a, $163 \mathrm{a}$.

218 Id. at app. 148a, $163 \mathrm{a}$.

219 Id. at app. 143a, 163 a.

220 Gambla, 853 N.E.2d at 857-59 (noting that the trial court only found Drs. Thomas and Alexander qualified to opine on the custody evaluators' methods); Petition for Writ of Certiorari, supra note 207, at app. 165a, 175a (expert reports of Anita Thomas, Ph.D., and Charles L. Alexander, Psy.D.) (showing that neither of the experts that testified for Kimberly had met with Kira and Christopher and that one had not met with Kimberly herself).

221 See Gambla, 853 N.E.2d at 858-59 (summarizing Dr. Thomas's and Dr. Alexander's trial testimony and showing that it focused primarily on critiquing methodological defects in Dr. Hynan's and Dr. Hatcher's approaches); see also id. at 875 (McLaren, J., dissenting) (dismissing Drs. Thomas's and Alexander's testimony as merely "inaccurate comments that [the custody evaluators] should have considered the race and circumstances of the parties when they conducted their tests").

222 Petition for Writ of Certiorari, supra note 207, at app. 165a, 175a.

223 Id. at app. 68a-69a (trial court opinion). 
American and because Kira is a biracial child, her custody should be awarded to [Kimberly]."224

The trial court-while claiming to reject this "broad stroke" approachwould nevertheless itself find race to be dispositive of Kira's best interest. ${ }^{225}$ After finding the parties equally deserving of custody under each of the statutory factors set out in Illinois's Marriage and Dissolution of Marriage Act, ${ }^{226}$ and rejecting each of the bases articulated by the custody evaluators for awarding custody to Christopher, the court noted that Kimberly, as a black woman, "will be able ... to provide Kira with a breadth of cultural knowledge and experience that [Christopher] will not be able to do."227 Based on this "special circumstance[]," the court concluded that Kimberly would be better able "to provide for the emotional needs of [Kira]" and awarded sole custody to Kimberly. ${ }^{228}$

On appeal, Christopher-by then proceeding pro se-argued to the Illinois Court of Appeals that this race-based decision was erroneous on both factual and legal grounds. ${ }^{229}$ But the court would reject each of Christopher's claims, finding as to the race issue that both Illinois law and federal constitutional doctrine permitted the use of race in a custody award.230 Thus, the court concluded that the trial court's decision, which also mentioned factors other than race (albeit none that it suggested might be dispositive), did not run afoul of constitutional or common law custody strictures. ${ }^{231}$ One justice dissented, contending, inter alia, that the trial court's use of race had been constitutionally impermissible. ${ }^{232}$

The Illinois Supreme Court denied review of the Illinois Court of Appeals decision on November 29, 2006.233 Thus, on February 27, 2007, Christopher

224 Id. at app. 68a.

$225 I d$. at app. 68a-69a.

226 For example, although Kira had a sibling in Kimberly's custody, the court found that the statutory factor of "interrelationship of the child with her parents, her siblings and any other persons who may significantly affect her best interests" weighed evenly in favor of both parties because Kira had a close and loving relationship with the relatives who lived with her father. Id. at app. 66a.

227 Id. at app. 68a-69a; see also Gambla, 853 N.E.2d at 873-76 (McLaren, J., dissenting) (arguing that the trial court's award of custody was based solely on race, and that the court erred in not accepting the qualified experts' recommendations).

228 Petition for Writ of Certiorari, supra note 207, at app. 69a.

229 See generally Gambla, 853 N.E.2d 847 .

230 Id. at 868-70.

231 See id. (finding that the trial court's multifactor analysis did not even require substantive constitutional scrutiny); see also Petition for Writ of Certiorari, supra note 207, at app. 63a-72a (making clear that the trial court considered the parties to be equally situated vis-à-vis all factors other than race).

232 See Gambla, 853 N.E.2d at 872-78 (McLaren, J., dissenting).

233 Gambla v. Woodson, 861 N.E.2d 654 (Ill. 2006). 
Gambla sought certiorari review from the United States Supreme Court. ${ }^{234}$ Focusing principally on Palmore v. Sidoti, Gambla's pro se petition argued that Palmore precluded precisely the type of dispositive reliance on race that had occurred in his case. ${ }^{235}$ If Palmore was to mean anything, Gambla contended, it must mean at least that "race cannot be the basis for the decision." 236 Moreover, he asserted, there was a conflict among the lower courts regarding Palmore's reach, further justifying a grant of certiorari. ${ }^{237}$

The odds for Gambla's petition-while well-written and sophisticated for a pro se submission - did not, a priori, look good. The Court very rarely grants pro se petitions of any kind, and the few such petitions that the Court does grant typically come from the in forma pauperis, or unpaid, docket, of which Gambla was not a part. ${ }^{238}$ Nevertheless, two months after Gambla filed his petition, the Court requested a response from Woodson's attorney. ${ }^{239}$ Such a "call for a response," while by no means dispositive of a grant of certiorari, does represent a significant improvement in a litigant's odds of receiving such a grant. ${ }^{240}$ The Court does not grant certiorari without a response on file, and will only call for a response when at least one Justice believes a grant might be warranted. ${ }^{241}$ Therefore, the Court's call for a response signals that a case has a better than average chance of being awarded review.

And indeed, it is not difficult to see why one or more of the Justices thought that review might be warranted in Gambla's case. At the time Gambla submitted his petition, the Court was in the final stages of deciding Parents Involved in Community Schools v. Seattle School District No. 1 (PICS), one of the most significant and controversial cases to deal with "benign" racial classifications during recent decades. ${ }^{242}$ Involving the use of race to achieve integrated schools at the elementary and secondary school level,

234 Petition for Writ of Certiorari, supra note 207.

235 Id. at $13-15$.

$236 \mathrm{Id}$. at 15

237 Id. at 16-19.

238 Kevin H. Smith, Justice for All?: The Supreme Court's Denial of Pro Se Petitions for Certiorari, 63 ALB. L. REV. 381, 383-84 \& n.6 (1999) (reviewing data regarding the Supreme Court's infrequent grants of certiorari to pro se petitioners).

239 Docket, No. 06-1193, Gambla v. Woodson, available athttp://www.supremecourt.gov/ Search.aspx?FileName=/docketfiles/o6-1193.htm (last updated Nov. 2, 2007).

240 David C. Thompson \& Melanie F. Wachtell, An Empirical Analysis of Supreme Court Certiorari Petition Procedures: The Call for Response and the Call for Views of the Solicitor General, 16 GEO. MASON L. REV. 237, 244 (2009) ("[A] petition [for certiorari] is 9 times more likely to be granted once the Court calls for a response.").

241 Id. at 242.

242 551 U.S. 701 (2007). 
PICS was widely perceived by both supporters and opponents as a significant opportunity for the Court to further limit benign uses of race. ${ }^{243}$

In fact the Court would-when it issued the PICS opinion in late June 2007-reaffirm the necessity of strictly scrutinizing all uses of race, while even more closely cabining the circumstances in which individual racial classifications are allowed. ${ }^{244}$ And although the majority in PICS did not speak with a wholly unified voice, with Justice Kennedy chiding his conservative colleagues for their simplistic endorsement of colorblindness in law, even Kennedy's own concerns-which centered primarily on the individual and community harms from treating an individual differently on the basis of race-seemed equally implicated by the use of race at issue in Gambla. ${ }^{245}$ Thus, Gambla - which categorically affirmed the constitutionality of using race to deprive a nonminority parent of custody, so long as race was not the exclusive factor-presented an obvious tension with the approach of the soon-to-be issued decision in PICS.

Nevertheless, Gambla would not be one of the cases for which a call for a response is a precursor to a grant of full review. On October 1, 2007, after the Court's return from its summer recess, the Court would deny Gambla's petition for certiorari. ${ }^{246}$ Gambla's petition for rehearing-filed shortly thereafter-would also be denied, bringing his four-year custody battle to an end. ${ }^{247}$

243 See, e.g., High Court to Rule on Racial Quotas, LAS VEGAS REV.-J., June 6, 2006, at 6B (noting that "[c]ourt watchers believe the acceptance of the case shows the court under new Chief Justice John Roberts intends to wade in and clear up the confusing legal status of 'affirmative action'”); Linda Greenhouse, Court Reviews Race as a Factor in School Plans, N.Y. TimES, June 5, 2006, at A1 ("At its most profound, the debate among the justices was over whether measures designed to maintain or achieve integration should be subjected to the same harsh scrutiny to which Brown v. Board of Education subjected the regime of official segregation. In the view of the conservative majority, the answer is yes."); Editorial, The High Court, Race and Education, WASH. TIMES, June 7, 2006, at A20 (citing the retirement of Justice O'Connor-who provided the swing vote in Grutter v. Bollinger - as an opportunity for the court to change "the race-based admissions policies that it enshrined in 2003"); David G. Savage, Barring Choice Based on Race Threatens Civil Rights, Some Say, San Jose Mercury News, Dec. 5, 2006, at A3 (noting that "[t]he Supreme Court justices, hearing arguments on school integration, signaled Monday that they are likely to bar the use of race when assigning students to public schools," and opining that this "would be a major victory for those who have called for 'color-blind' decision-making by public officials").

244 See PICS, 551 U.S. at 720-25, 733-35; see also id. at 725-33, 735-48 (plurality opinion); id. at $748-82$ (Thomas, J., concurring) (arguing even more strongly for tightly circumscribing the use of race).

245 See PICS, 551 U.S. at 795-98 (Kennedy, J., concurring) (articulating concerns that racial classifications are "divisive" and can lead to a "corrosive discourse").

246 Gambla v. Woodson, $55^{2}$ U.S. 810 (2007).

247 Petition for Rehearing, Gambla, $55^{2}$ U.S. 810 (No. 06-1193), pet. denied, $55^{2}$ U.S. 1056 (2007). 


\section{POSTSCRIPT: THE 2012 TERM}

On January 4, 2013-thirty-five years after Bakke and Drummond-the Court would once again face the question it had faced in Drummond: whether to take up an adoption case in the same term as a major affirmative action decision. ${ }^{248}$ Just as thirty-five years ago, Bakke - by then fully briefed and argued-provided the backdrop to the Court's consideration of whether to grant review in Drummond, Fisher v. University of Texas at Austin-the Court's first major affirmative action case in nearly a decade-was fully argued and awaiting decision when the Court met to decide whether to grant review for this new adoption case. ${ }^{249}$

The facts of the new adoption case also bore striking similarities to the Drummonds' own circumstances in 1978. Like Drummond, the petitioners in the pending case had raised a child essentially from birth, only to see the child removed from their home as a toddler. ${ }^{250}$ And, like Drummond, the facts left little doubt that the child's heritage played a key role in the removal (although here at issue was a federal law preferencing Indian parents for Indian children, not a state race-matching policy). ${ }^{251}$ In both cases, the prospective adoptive parents were undisputedly loving and competent parents, with deep attachments to the child removed from their home. ${ }^{252}$

But this new case-Adoptive Couple v. Baby Girl-was also fundamentally distinct from Drummond in critical respects. ${ }^{253}$ Unlike in Drummond, the

248 See Docket, No. 12-399, Adoptive Couple v. Baby Girl, available at http:// www.supremecourt.gov/Search.aspx?FileName=/docketfiles/12-399.htm (last updated July 5, 2013); see also Fisher v. Univ. of Tex. at Austin, 631 F.3d 213 (5th Cir. 2011), cert. granted, 132 S. Ct. 1536 (2012); Docket, No. 11-345, Fisher v. Univ. of Tex. at Austin, available at http://www.supremecourt.gov/ Search.aspx?FileName=/docketfiles/11-345.htm (last updated Aug. 16, 2013).

249 See Regents of the Univ. of Cal. v. Bakke, 438 U.S. 265 (1978) (showing that Bakke was argued October 12, 1977, and decided June 28, 1978); see also Docket Sheet, No. 77-1381, Drummond v. Fulton Cnty. Dep't of Family \& Children's Servs. (June 19, 1978) (on file with the Library of Congress, Harry A. Blackmun Papers) (showing that the Drummond petition for certiorari was filed in March 1978, and the vote to deny certiorari was held in mid-June 1978); cf. Memorandum from K.E. on No. 77-1381, Drummond v. Fulton Cnty. Dep't of Family \& Children's Servs., to the Cert Pool 13 (June 1, 1978) (on file with the Library of Congress, Harry A. Blackmun Papers) (arguing against a hold on Drummond despite the fact that Bakke was pending, because the cases "arise in such different factual context[s]").

250 Drummond v. Fulton Cnty. Dep't of Family \& Children's Servs., 547 F.2d 835, 837 (5th Cir. 1977); Adoptive Couple v. Baby Girl, 731 S.E.2d 550, 554-55 (S.C. 2012).

251 Compare Drummond v. Fulton Cnty. Dep't of Family \& Children's Servs., 563 F.2d 1200, 1204-06 (5th Cir. 1977) (en banc), with Adoptive Couple, 731 S.E.2d at 555-56.

252 See Drummond, 547 F.2d at 841-46; Adoptive Couple, 731 S.E.2d at 567.

253 I focus here on the legal differences between Adoptive Couple and Drummond, but there were important factual differences as well. Most important, in Adoptive Couple, Baby Girl's biological father desired to raise her and was the party contesting the adoption. It was only 
predominant issues presented for review in Adoptive Couple were statutory, not constitutional, arising under the federal Indian Child Welfare Act (ICWA). ${ }^{254}$ And, to the extent that constitutional concerns might be implicated (as the Petitioners and the guardian ad litem suggested), it was far from clear that strict scrutiny-as opposed to rational basis reviewwould apply. ${ }^{255}$ Because the ICWA applied by virtue of Baby Girl's "Indian" status - a status the Court has traditionally treated as political, rather than racial-even plenary consideration of Adoptive Couple would not (unlike the cases that had come before) require the Court to directly take up the conflict with its affirmative action precedents that it had long sought to avoid. ${ }^{256}$

And indeed, the outcome for the prospective adoptive parents in Adoptive Couple (the Capobiancos) would ultimately differ dramatically from that faced by the Drummonds. In January 2013, the Court would-unlike in Drummond-grant certiorari review in Adoptive Couple. ${ }^{257}$ Ultimately, the Court would interpret the ICWA to hold that state law, not the ICWA's Indian-specific provisions, must control. ${ }^{258}$ As such, the Court would hold that no bar existed under federal law to Baby Girl's adoption by the Capobiancos, a holding that would later result in the return of Baby Girl to the Capobianco's custody for adoption. ${ }^{259}$

because of the specifics of South Carolina state law (which did not require the consent of a biological father to adoption where the father was not involved during the pregnancy or immediately post-birth) that the ICWA issues became the focus of the proceedings.

254 Compare Federal Drummond Petition, supra note 43, at 4-5, 25-27 (arguing for strict scrutiny to review the use of race discrimination in adoption and analogizing to then-pending Bakke), with Petition for a Writ of Certiorari, Adoptive Couple v. Baby Girl at *ii, 133 S. Ct. $255^{2}$ (2013) (No. 12-399) [hereinafter Adoptive Couple Petition] (presenting only statutory questions for review). But cf. Adoptive Couple Petition, supra, at 26 (suggesting that equal protection principles should inform the statutory analysis); Response of Guardian Ad Litem at *10-12, Adoptive Couple, 133 S. Ct. 2552 (No. 12-399) (raising the equal protection issue prominently).

255 See infra note 256 and accompanying text.

256 See Morton v. Mancari, 417 U.S. 535, 553-54 (1974) (finding that the hiring preferences given to Indians within the Bureau of Indian Affairs were distinct from invidious race discrimination because they were not racial preferences, but rather "employment criteri[a] reasonably designed to further the cause of Indian self-government"); $c f$. Regents of Univ. of Cal. v. Bakke, 438 U.S. 265, 304 n.42 (1978) (Powell, J.) (rejecting the view that Mancari supported the argument that something less than strict scrutiny should be applied on the grounds that the classification at issue in Mancari "was not racial at all").

257 Adoptive Couple v. Baby Girl, 133 S. Ct. 831 (2013) (granting certiorari review).

258 Adoptive Couple, 133 S. Ct. at 2565.

259 Id.; see also Adoptive Couple v. Baby Girl, 404 S.C. 490, 492-493 (2013) (holding, on remand, that Baby Girl must be removed from her biological father's home and returned to her prospective adoptive parents for the finalization of the adoption). See generally Father Is Ending Battle for Custody, TULSA WORLD (Oct. 11, 2013), http://www.tulsaworld.com/news/father-is-ending-battle-for-custody/ 
Moreover, the Court would, for the first time in Adoptive Couple seem to express a less than fully approving view of certain forms of heritage-based adoption decisionmaking. Mirroring long-time legal and social norms essentializing those of only partial Native American heritage as non-Indian, the Court would repeatedly signal its discomfort with applying the ICWA's Indian preferences to someone of Baby Girl's "remote" Native American ancestry. ${ }^{260}$ Characterizing the application of the ICWA's provisions in such a context as a "great disadvantage," the Court would ultimately conclude that the statute's application in Adoptive Couple "would raise equal protection concerns." ${ }^{261}$ Thus, at least with regard to those like Baby Girlperceived by the Court as not being truly of the heritage ascribed to her under the law-Adoptive Couple seemed to signal, for the first time, the Court's perception of certain race-matching prescriptions as less than fully benign. ${ }^{262}$

But ultimately, despite these signs of the Court's discomfort with the ICWA's potential reach, Adoptive Couple would do little to disrupt the existing, constitutionally permissive, race/family law regime. ${ }^{263}$ Thus, the

article_125eb3a1-77db-57d5-9f 4a-e71612be7502.html (detailing the timeline of the Adoptive Couple legal dispute).

260 See, e.g., Adoptive Couple, 133 S. Ct. at 2556, 2559, 2565 (repeatedly noting the precise quantum of Baby Girl's blood heritage, and characterizing it as "remote"). This anxiety over an insufficient biological nexus to Indian status-while irrelevant as a matter of equal protection doctrine-tracks the historical tendency to essentialize those with relatively little Native American status as non-Native American, a tendency that has been precisely reversed in the context of African Americans. See, e.g., Kevin Noble Maillard, The Pocahontas Exception: The Exemption of American Indian Ancestry From Racial Purity Law, 12 MICH. J. RACE \& L. 351, 372 (2007); cf. Gregory Ablavsky, Comment, Making Indians "White": The Judicial Abolition of Native Slavery in Revolutionary Virginia and its Racial Legacy, 159 U. PA. L. REV. 1457, 1515-19 (2011) (describing the historical legal categorization of Indians as "white" and government efforts to convert Indian cultural practices).

261 Adoptive Couple, 133 S. Ct. at 2565.

262 It is not clear that this specific discomfort is a signal of a broader disapproval on the Court of the use of race or heritage in adoption. To the extent that the key concern in Adoptive Couple was Baby Girl's insufficient Native American heritage (as the majority opinion's repeated allusions to her blood quantum suggest), the crux of the Court's concern appears to have been that she was inaccurately race-matched, not the fact of the utilization of racial or ethnic heritage in the adoption process. Cf. Reisman v. Tenn. Dep't of Human Servs., 843 F. Supp. 356, 363-66 (W.D. Tenn. 1993) (finding a violation of equal protection where an agency race-matched biracial children with black parents, but ordering instead that "bi-racial children shall be placed in foster homes and in adoptive homes with bi-racial families"-i.e., that they should be even more specifically race matched).

263 From a constitutional perspective, the status quo vis-à-vis remaining race-based family law practices remains largely unchanged today. Thus, while such cases are less frequent today (due in part to the changes brought about by MEPA), multiple jurisdictions continue to have nonoverruled decisions affirming the constitutionality of using race in adoption, foster care, or interracial custody disputes when race is not the sole factor. See, e.g., J.H.H. v. O'Hara, 878 F.2d 
majority opinion in Adoptive Couple would-despite hinting obliquely at potential constitutional concerns-ultimately leave all of the ICWA's core provisions intact. ${ }^{264}$ Indeed, despite the sharp disagreements that Adoptive Couple generated among the Justices, no Justice-in the majority or the dissent-would suggest that the ICWA's core heritage-based provision (mandating the preferential placement of Indian children with other Indians) must be struck down. ${ }^{265}$

Nor would any member of the Court suggest that strict scrutiny-and the meaningful constitutional examination that it entails-must be applied

240, 241-45 (8th Cir. 1989) (awarding qualified immunity in a case where the agency had a policy stating that "[m]inority children shall be placed with families of similar racial and ethnic characteristics"), cert. denied, 493 U.S. 1072 (1990); Drummond v. Fulton Cnty. Dep't of Family \& Children's Servs., 563 F.2d 1200, 1204-06 (5th Cir. 1977) (en banc), cert. denied, 437 U.S. 910 (1978); Tallman v. Tabor, 859 F. Supp. 1078, 1085-88 (E.D. Mich. 1994); Child v. Stangler, No. 92-0850, 1992 U.S. Dist. LEXIS 19954, at *7-9 (W.D. Mo. Dec. 28, 1992) (noting in dicta that relying on race as a factor is not improper in an adoption proceeding); In re F.W., 870 A.2d 82, 86-87 (D.C. 2005) (affirming that race is a proper consideration in adoption determinations); In re Petition of D.I.S., 494 A.2d 1316, 1319-27 (D.C. 1985); Drummond v. Fulton Cnty. Dep't. of Family \& Children's Servs., 228 S.E.2d 839, 844 (Ga. 1976) (finding that "the Drummonds ha[d] no rights under the Fourteenth Amendment" and thus no standing to contest denial of adoption based on race), cert. denied, 432 U.S. 905 (1977); Gambla, 853 N.E.2d 847, 868-70 (Ill. App. Div. 2006), cert. denied, 552 U.S. 810 (2007); Gloria G. v. State Dep't of Soc. \& Rehab. Servs., 833 P.2d 979, 984-86 (Kan. 1992); In re Adoption/Guardianship No. 2633, 646 A.2d 1036, 1042-49 (Md. 1994); In re Dep't of Soc. Servs., 453 N.E.2d 1236, 1237, 1239 (Mass. App. Ct. 1983), aff'd on other grounds, 461 N.E.2d 186 (Mass. 1984); In re Carpenter, No. 21634, 1999 Mich. App. LEXIS 2140, at *9-11 (Mich. Ct. App. Dec. 3, 1999); Carlson v. County of Hennepin, 428 N.W.2d 453, 455, 458 (Minn. Ct. App. 1988) (granting qualified immunity to the adoption agency in a case where the prospective parents were informed that "it would be against county policy to allow a white couple to adopt a black child"), cert. denied, 490 U.S. 1023 (1989); Brown v. Brown, 621 N.W.2d 70, 82-83 (Neb. 2000); In re Haven, No. C-780343, 1979 Ohio App. LEXIS 9744, at *6-16 (Ct. App. Aug. 1, 1979); cf. In re Moorehead, 6oo N.E.2d 778, 784-89 (Ohio Ct. App. 1991) (invalidating, in different appellate district than Haven, an agency's exclusive use of race to disqualify an adoptive family).

Four other states have never reached the constitutional issue but have permitted uses of race in adoption, foster care, or interracial custody disputes as a matter of state law. See, e.g., In re Marriage of Mikelson, 299 N.W.2d 670 (Iowa 1980); Savage v. Cota, 885 N.Y.S.2d 798 (App. Div. 2009); Davis v. Davis, 658 N.Y.S.2d 548 (App. Div. 1997); In re Davis, 465 A.2d 614 (Pa. 1981) (ambiguous whether based on constitutional analysis or state law); In re Adoption of A.S.H., 674 A.2d 698 (Pa. Super. Ct. 1996) (same); Ward v. Ward, 216 P.2d 755 (Wash. 1950); Tucker v. Tucker, 542 P.2d 789 (Wash. Ct. App. 1975) (affirming that race can be a factor in custody disputes between interracial parents, albeit not the sole factor).

264 Adoptive Couple, 133 S. Ct. at 2565 (suggesting that constitutional concerns would be raised by a different result). But cf. id. at 2564 (leaving intact ICWA's statutory preference framework). The opinion leaves intact, inter alia, a statutory framework which prefers members of the child's tribe and "other Indian families" above other competing adoptive families, finding it to be inapplicable based purely on the technical grounds that no competing adoption petitions had been filed. Id. at $2564-65$

265 See supra note 264; see also Adoptive Couple, 133 S. Ct. at 2572 (Sotomayor, J., dissenting) (discussing $§ 1915$ 's placement preferences). 
as the applicable constitutional standard of review. Indeed, the majoritydespite its brief allusion to equal protection-would itself apply no meaningful constitutional scrutiny to the ICWA, nor otherwise signal that a strict scrutiny standard might be appropriate. ${ }^{266}$ And five of the Justices in Adoptive Couple-including race conservatives such as Justices Thomas and Scalia-would entirely eschew an equal protection-based rationale, electing instead to rely on purely statutory or unrelated constitutional rationales. ${ }^{267}$ Thus, despite the Court's virtually simultaneous reaffirmance of its "colorblind" approach to affirmative action doctrine in Fisher, it would not, in Adoptive Couple, seek to extend that doctrine to the family law domain. ${ }^{268}$

Therefore, Adoptive Couple - far from staging a revolutionary incursion into the lower courts' permissive approach to the use of race in family lawwould instead continue the Court's long-standing hands-off approach. Three and a half decades after Drummond and Bakke, the Court would again elect to leave the affirmative action-family law divide essentially undisturbed. ${ }^{269}$ Although much had arguably changed since Drummond - with the Court's colorblindness "revolution" unfolding across a series of landmark cases-the Court's constitutional approach to family law would change little; continuing as ever it had before.

266 See Adoptive Couple, 133 S. Ct. at 2565 (alluding briefly to potential "equal protection concerns" but without applying strict scrutiny to the ICWA's provisions or otherwise suggesting that strict scrutiny would be the appropriate standard of review).

267 Id. at 2570 n.3 (Thomas, J., concurring); id. at 2584-85 (Sotomayor, J., dissenting) (joined in relevant part by Justices Ginsburg, Kagan, and Scalia). The dissenters addressed the equal protection issue, but concluded that no equal protection concern existed, given that classifications based on Indian tribal membership have traditionally been treated as non-racial. See id. at 2584-85 (Sotomayor, J., dissenting).

268 See Fisher v. Univ. of Tex. at Austin, 133 S. Ct. 2411, 2417 (2013) (holding that any racial classification, including those that "may seem benign," must be subject to strict scrutiny). I do not mean to suggest here that it was erroneous for the dissenters in Adoptive Couple to treat the ICWA context as distinctive due to the Court's historical treatment of Indian status as a political, rather than racial, status. Rather, the point here is that to the extent the Court viewed the classifications at issue in Adoptive Couple as racial, rather than political, it entirely declined to apply the framework that it has otherwise deemed applicable in the affirmative action context. For further elaboration of this point, see infra note 276 .

269 There are many possible factors that complicate any attempt to understand Adoptive Couple simplistically, including the different cultural and legal salience that has traditionally attached to Indian status. Cf. supra note 260 . Thus, although it is undoubtedly accurate that the Court did not elect to use the case as a basis for eliminating (or even meaningfully narrowing) the affirmative action-family law divide, it is certainly plausible that a much more complicated set of considerations may have been at work in Adoptive Couple than in some of the other cases in which the Court has declined to intervene entirely. Unfortunately, access to the Justices' papers (which might allow a fuller understanding of the internal dynamics in Adoptive Couple) will likely not be available for a very long time. 


\section{IMPLICATIONS}

There are two very different stories to be told of the history of the Court's constitutional race law jurisprudence. The first-told by the Court itself in its affirmative action opinions - is one in which context has mattered little. ${ }^{270}$ Under this account, what has mattered to the Court is not any contextual factor-such as whether a particular racial classification may be categorized as putatively benign-but instead simply the use of race itself. Government uses of race are simply too categorically divisive, too inherently problematic, to be exempted from strict scrutiny review on any grounds. Instead, equal protection has demanded (and continues to demand) that the Court strive toward colorblindness and cabin uses of race to the narrowest of circumstances; only where they may be characterized as "narrowly tailored" to meet a "compelling state interest." This account, then, is one in which consistency-across all of race law's many domains-is treated as doctrinally demanded of the Court and held out as empirically true.

But a very different story is told by the history of the Court's involvement in contemporary race-based family law practices. ${ }^{271}$ Here, many of the same Justices who have rejected contextual variability in the affirmative action context have taken the opposite approach: they have embraced variable standards and rejected consistency as the rubric that the constitution demands. Thus, many of the same Justices who have formed the Court's majority on affirmative action-far from demanding the uniform application of strict scrutiny in the family law context-have consistently avoided the application of strict scrutiny to contemporary race-based family law practices. And these actions, it seems, have been based precisely on the types of normatively based considerations that the Court's race conservatives have, in the affirmative action context, decried.

Some might resist this account, so far from the Court's own. But it is difficult to read the historical record otherwise. Thus, Palmore v. Sidotilong conceptualized by scholars in terms consistent with the Court's own account-is cast in a far different light by the archival records available today. Despite its contemporary canonical status, Palmore was not a case the Court's race conservatives wanted to take up. ${ }^{272}$ And, when the Court's liberal wing (joined by Justice Stevens) nevertheless voted to do so, the Court's race conservatives successfully advocated to limit its reach, based precisely on the perception that the remaining uses of race in family law

270 For further discussion and sources, see generally supra Introduction and Part III.

271 For further discussion and sources, see generally supra Sections I-V.

272 See supra notes 100-01 and supra notes 126-28 and accompanying text. 
were fundamentally "different" and benign. ${ }^{273}$ Thus, the lower courts' response to Palmore-as of marginal significance outside of its specific context-appears to be exactly that intended by the Court's race conservatives and race moderates, rather than an aberrational or willful misreading. ${ }^{274}$

Nor did the Court embrace the much more recent opportunity afforded to it to bring its affirmative action and family law jurisprudence into alignment. ${ }^{275}$ Although the race discrimination issue was strongly argued by both the petitioners and guardian ad litem in Adoptive Couple v. Baby Girl, the Court itself restricted its equal protection analysis to a single ambiguous sentence. ${ }^{276}$ Moreover, two of the Court's leading race conservativesJustices Scalia and Thomas-declined to endorse even this soft statement, eschewing any form of equal protection-based rationale. ${ }^{277}$ Thus, despite the strength of the rhetoric that the Court's race conservatives have deployed in arguing for the inherent invidiousness of any race-based practices, their actions in the family law context reflect a far different approach.

And although the Court's reticence in Adoptive Couple might be explained by its particular context (involving primarily statutory issues and arising in the Indian law context), context cannot similarly explain the entirety of the Court's decades-long silence on the lower courts' loose and permissive approach to race in the family. Since the mid-1970s, litigants have repeatedlyin cases squarely presenting the issue-urged the Court to take up and address its family law-affirmative action divide. In every single one of those cases, the court below declined to apply strict scrutiny review. And in every

273 See supra notes 133-42 and supra notes 166-69 and accompanying text.

274 Compare supra note 273, with supra notes 185-91 and accompanying text. See generally supra Sections II-III.

275 See generally supra notes 263-69 and accompanying text.

276 Adoptive Couple v. Baby Girl, 133 S. Ct. 2552, 2565 (2013); see also Brief for Petitioners at 44-47, Adoptive Couple, 133 S. Ct. $255^{2}$ (No. 12-399); Brief for Guardian ad Litem at 53-55, Adoptive Couple, 133 S. Ct. $255^{2}$ (No. 12-399). Even in this single sentence, the Court did not explicitly state that it viewed the ICWA as entailing a race-based classification, although it implied as much. Adoptive Couple, 133 S. Ct. at 2565. I do not mean to suggest here that the Court should have viewed the ICWA's provisions as involving a racial, rather than political, designation for equal protection purposes. Cf. id. at 2584-85 (Sotomayor, J., dissenting) (contending that the ICWA's classifications should be considered nonracial under the Court's precedents). I simply observe that-to the extent the majority viewed the issue as a racial one-they failed to apply the constitutional framework that the Court reaffirmed as a categorical imperative just the previous day. See Fisher v. Univ. of Tex. at Austin, 133 S. Ct. 2411, 2417-19 (2013) (reiterating that "[a]ny racial classification must meet strict scrutiny" and that racial classifications are inherently "odious" and "inherently suspect" (citations omitted)).

277 Adoptive Couple, 133 S. Ct. at 2570 n.3 (Thomas, J., concurring); id. at 2585 (Sotomayor, J., dissenting); $i d$. at 257-72 (Scalia, J., dissenting) (stating that he joined Justice Sotomayor's dissent "except as to one detail" of her statutory reasoning unrelated to the equal protection analysis). 
one of those cases, the litigant challenging the use of race lost below. Yet, in every case for which we have internal records, including Palmore, each of the Court's race conservatives uniformly voted against certiorari review. ${ }^{278}$ In contrast, the vast majority of the Court's race liberals and race moderates have cast votes in favor of certiorari review. ${ }^{279}$

Nor is it plausible to ascribe this uniform pattern simply to the vagaries of certiorari review. To be sure, the Court turns down many cases for reasons that are wholly unrelated to their merits. ${ }^{280}$ But the cases that have reached the Court have included a vast array of compelling circumstances: cases in which the court below found race to be the sole cause, cases in which there was a categorical policy of placing minority children with minority families, cases in which no Justice disputed that race was dispositive. ${ }^{281}$ Under these circumstances, it is difficult-if not impossible-to

278 Docket Sheet, No. 92-616, Sharp v. Hennepin County (on file with the Library of Congress, Harry A. Blackmun Papers); Docket Sheet, No. 90-123, Wilson v. Darrow (on file with the Blackmun Digital Archive); Docket Sheet, No. 89-906, J.H.H. v. O'Hara (on file with the Library of Congress, Thurgood Marshall Papers); Docket Sheet, No. 88-6265, Carlson v. County of Hennepin (on file with the Blackmun Digital Archive); Docket Sheet, No. 82-1734, Palmore v. Sidoti (on file with the Washington and Lee University School of Law, Lewis F. Powell, Jr., Papers); Docket Sheet \#2, No. 82-1734, Palmore v. Sidoti (on file with the Washington and Lee University School of Law, Lewis F. Powell, Jr., Papers); Docket Sheet, No. 82-1734, Palmore v. Sidoti (on file with the Library of Congress, William J. Brennan, Jr., Papers); Docket Sheet, No. 82-1734, Palmore v. Sidoti (on file with the Library of Congress, Harry A. Blackmun Papers); Docket Sheet, No. 76-984, Drummond v. Fulton Cnty. Dept. of Family \& Children's Servs. (on file with the Library of Congress, Byron R. White Papers); Docket Sheet, No. 77-1381, Drummond v. Fulton County Dep't of Family \& Children's Servs. (on file with the Library of Congress, Harry A. Blackmun Papers); see also Docket Sheet, A-664, Palmore v. Sidoti (on file with the Washington and Lee University School of Law, Lewis F. Powell, Jr., Papers) (Palmore stay proceedings); Memorandum of Thurgood Marshall on No. A-664, Palmore v. Sidoti, to the Conference (Mar. 3, 1983) (on file with the Washington and Lee University School of Law, Lewis F. Powell, Jr., Papers) (Palmore stay proceedings).

279 See supra note 278.

280 Compare Teague v. Lane, 489 U.S. 288, 296 (1989) (explaining that because of the range of considerations that can lead to a denial of certiorari review, such denials do not have the same effect as a decision on the merits), with McDonald v. City of Chicago, 130 S. Ct. 3020, 3094 (2010) (Stevens, J., dissenting) (ascribing substantive legal meaning to the Court's pattern of certiorari denials despite recognizing their lack of precedential weight).

281 See, e.g., J.H.H. v. O'Hara, 878 F.2d 240, 243-45 (8th Cir. 1989) (dismissing a lawsuit challenging a race-based foster care decision made pursuant to a policy requiring placement of minority children with families of "similar racial and ethnic characteristics"), cert. denied, 493 U.S. 851 (1990); In re Adoption/Guardianship No. 2633, 646 A.2d 1036, 1048-49 (Md. Ct. Spec. App. 1994) (acknowledging that race was the sole consideration in an agency's foster care/adoption determination, but nevertheless upholding the placement decision), cert. denied, 516 U.S. 809 (1995); see also supra note 130 (documenting that all Justices appear to have agreed in Palmore that race was the dispositive or at least predominant factor in the lower court's decision). 
conclude that the Court has simply been unable to find an appropriate vehicle for review. ${ }^{282}$

Thus, it appears that the Court's absence from contemporary debates over the use of race in family law has been far from the product of mere oversight. Family law has been conceived of as simply too "different"-the use of race there too "natural" and benign - to warrant the type of intervention that has historically been demanded in the affirmative action context. Instead, the Court has self-consciously-but sub silentio-endorsed the lower courts' loose and permissive approach to race in family law, an approach that has predictably allowed all but the most extreme contemporary instantiations of race-based family law decisionmaking to endure.

This approach to family law stands in stark contrast to the doctrinal justifications that the Court has offered in support of its affirmative action regime. ${ }^{283}$ Thus, the Court's approach to affirmative action-demanding uniform strict scrutiny, with predictably harsh results-has been justified precisely by reference to the impermissibility of a contextually or normatively

282 Another alternative explanation-that the Court has avoided such cases because they involve family law, rather than race-based family law per se-is neither persuasive nor relevant, even if true. To be sure, the Court has long exceptionalized family law as a bastion of state control in which the federal courts have little business intervening. See, e.g., Jill Elaine Hasday, Federalism and the Family Reconstructed, 45 UCLA L. REV. 1297, 1297-1310 (1998). But with the exception of certain narrow doctrinal contexts, all inapplicable here (such as the domestic relations to diversity jurisdiction), the Court has, in fact, felt free to intervene regularly in family law disputes. See, e.g., David D. Meyer, The Constitutionalization of Family Law, 42 FAM. L.Q. 529, 529 (2008) (observing that the Court's decisions have "fundamentally redefined" American family law, refocusing its central discourse on rights in a way unimaginable under the old regime (quoting Michael Grossberg, How to Give the Present a Past? Family Law in the United States, 1950-200o, in CROSS CURRENTS: FAMILY LAW AND POLICY IN THE UNiTED STATES AND ENGLAND 3 (Sanford Katz et al. eds., 2000))); see also Hasday, supra (challenging, persuasively, the Court's rhetorical characterization of family law as a bastion of state control, outside the Court's and the federal government's bailiwick); HASDAY, supra note 16, at 28-68 (same).

Moreover, even if the Court's reluctance to scrutinize continued uses of race in family law has derived in part from a generalized reluctance to scrutinize family law issues, such a contextually based resistance to applying strict scrutiny is nevertheless clearly inconsistent with the Court's articulated categorical approach. See supra notes $175-83$ (chronicling the Court's justifications for its doctrinal approach to affirmative action, based precisely on rhetorical and normative claims that context does not and cannot matter in determining the level of scrutiny applied to government uses of race). The Court has sanctioned a regime in which all uses of race, regardless of context, must be subjected to the most rigid form of review because of their inherent harms. It is just as inconsistent for the Court to decline to compel the application of strict scrutiny to an area because it is one in which it wishes to reduce its institutional profile as it is for the Court to do so because of any of the other contextually based considerations that might cause the Court to desire to permit greater flexibility in race-based state decisionmaking. Cf. United States v. Lopez, 514 U.S. 549, 564-68 (1995) (articulating federalism-based concerns about federal intervention in both education (the primary locus of affirmative action decisions) and family law).

283 For further discussion and sources, see generally supra Introduction and Part III. 
variable approach. It is impossible to take context into account, we are told, precisely because the use of race by government is - in every context-so inherently dangerous and malign. Thus the Court's aggressive intervention is not only permissible, but essential, lest the perils of racial decisionmaking infuse our constitutional polity with their inevitable divisiveness and stigmatic harms. In short, the formal doctrinal position articulated by the Court in its affirmative action precedents has presumed harm to flow from all government uses of race, leaving no room for the type of contextual variability it has in fact allowed. ${ }^{284}$

This divergence between the Court's formal race law doctrine and its actual approach creates profound process, legitimacy, and substantive concerns. Because the Court has explicitly articulated a particular doctrinal rule-that no deviations are permitted from strict scrutiny's inexorable command-while sub silentio following a different approach, it has deprived litigants and the public of the ability to fully participate in one of the most important debates in contemporary American constitutionalism (i.e., which contemporary uses of race should be permitted to endure). ${ }^{285}$ Moreover, the Court's current approach-unguided by fixed legal standards, and conducted out of sight of any public scrutiny-of necessity puts the Justices in the position of picking and choosing which uses of race to favor based on no more than their own normative intuitions. Such a regime cannot, in the

284 Shorn of this absolutist justification, it is difficult to see what props up the contemporary affirmative action regime. That is, if the Court does, in fact, deploy a contextually variable approach to deciding whether to apply strict scrutiny, it is not at all clear why affirmative action, but not, for example, family law or race-based suspect selection, should fall on the strict scrutiny side of the divide. Indeed, precisely because the Court has relied so extensively on the assumption that strict scrutiny is categorical, it has done little work to truly substantiate affirmative action's purported harms.

285 To be sure, litigants have been able to participate at the margins of this debate. But in a regime where the Court has formally denied that context matters to whether or not strict scrutiny applies, litigants are largely excluded from the Court's decisions as to which context-based factors will, in fact, be deployed. This dynamic is rendered even more problematic by the fact that the strict scrutiny framework itself, as the Court has construed it, allows de minimis real evaluation of a racial practice's harms or benefits and thus does not offer an alternative mechanism for this type of evidence or argumentation to be introduced. For example, strict scrutiny does not encompass any real world evaluation of the harms or lack of harms of a particular racial practice, and instead presumes such harms. And while benefits of a practice may be considered as part of the "compelling state interest" analysis, the Court has so significantly narrowed what may be considered a compelling interest that most of the factors that one might want to consider in assessing whether a particular racial classification is normatively justified are legally irrelevant. See, e.g., Shaw v. Hunt, 517 U.S. 899, 909-10 (1996) ("[A]n effort to alleviate the effects of societal discrimination is not a compelling state interest."); Wygant v. Jackson Bd. of Educ., 476 U.S. 267 (1985) (finding that the desire to provide role models is not a compelling state interest); see also Fisher v. Univ. of Tex. at Austin, 133 S. Ct. 2411, 2417 (2013) (characterizing Bakke as having held that "[r]edressing past discrimination could not serve as a compelling interest" in the university context). 
long term, be sustained without fundamental damage to the Court's legitimacy as the ultimate arbiter of constitutional race law doctrine. ${ }^{286}$

As importantly, such a regime seems likely to inexorably lead to distortions in the further development of constitutional race law jurisprudence. Explicitly disclaiming the salience of contextual and normative factors while in fact attending to them sub rosa predictably leads to doctrinal confusion and inconsistency. Indeed, arguably a number of the most incoherent and logically tortured features of both the Supreme Court's and the lower courts' constitutional race law jurisprudence have derived from the attempt to fit preferred racial practices (including, but not limited to, family law) within the Court's contextually unvarying race law framework. ${ }^{287}$ Thus, the divergence between doctrine and practice seems likely to lead only to the further fragmentation and intellectual disintegration of race law doctrine, stripping it of even the limited veneer of fairness that it derives from its putative mandate of consistency today.

Perhaps, then, prior family law litigants have been right: what is needed is for the Court to take up and address contemporary uses of race in family law and to bring them under the strict scrutiny rubric. Indeed, if family law stood alone, such an approach might-despite the long historical recordseem the most plausible approach. There can be no doubt that the Court has, if anything, turned further toward constitutional colorblindness in recent years, nor that many of its Justices have a deeply felt normative commitment to eradicating at least certain uses of race from contemporary public life. And Adoptive Couple signals that, although the Court has so far been unwilling to extend its doctrine, there may indeed be instances of racebased family law decisionmaking that at least some of its Justices perceive as

286 Whatever the merits or drawbacks of the Court's claimed approach to race in the law, it has the veneer of adherence to the rule of law, of an evenhanded and neutral decisionmaking principle. Absent such a veneer, the Court's actions begin to look troublingly like race politics. For all the reasons that the Court's race moderates have emphasized, such appearances-whatever the reality-matter. See generally Siegel, Antibalkanization, supra note 12. Indeed, few would dispute that it is deeply divisive for the Court to be perceived as a naked power player in the continuing debates over the proper role of race in American society. Cf. Banks, Race-Based Suspect Selection, supra note 5, at 1120 (making a similar point in the context of discussing the problems with treating race-based suspect selection as constitutionally exceptional).

287 See supra Parts I-V; see also Banks, Race-Based Suspect Selection, supra note 5, at 1108-25 (discussing race-based suspect selection); Siegel, Antibalkanization, supra note 12, at 1361 (same); cf. Grutter v. Bollinger, 539 U.S. 306, 326 (2003) (holding that in the disfavored context of affirmative action, only the use of race as a factor is required to trigger strict scrutiny); Miller v. Johnson, 515 U.S. 900, 916 (1995) (finding that in the favored context of redistricting, the plaintiff must show that race was the "predominant factor" to trigger strict scrutiny). 
malign. ${ }^{288}$ Thus, it is plausible that, were the Court faced with the need to align its family law and affirmative action doctrines, affirmative action's putatively categorical approach would endure.

But family law does not stand alone in its current exemption from the Court's putatively categorical colorblindness revolution. As scholars such as Rick Banks and Reva Siegel have observed, family law is only one of a number of areas-including race-based suspect selection, nonclassifying (but race-intentional) efforts to promote integration, and other nonindividualized efforts to promote substantive equality-in which the lower courts have consistently declined to apply strict scrutiny review, and in which the Supreme Court has consistently declined to intervene. Indeed, despite affirmative action law's ostensibly categorical command, there are relatively few areas to which the Court has formally extended its reach. ${ }^{289}$ Thus, there remain today many areas in which governments (state, local, and federal) continue to make open and pervasive use of race, as to which the Court has traditionally declined to apply strict scrutiny review.

There are strong reasons to believe that the Court is - at least at presentunprepared to dramatically reshape this very partial regime. Thus, although there have been hints across a number of domains that the Court has begun to problematize racial practices that have long remained effectively unscrutinized, it has so far shown itself far from willing to fully embrace the implications of a truly colorblind race law regime. ${ }^{290}$ Indeed, several of the

288 See Adoptive Couple v. Baby Girl, 133 S. Ct. 2552, 2565 (2013) (characterizing the application of the ICWA as a disadvantage, rather than a benefit, at least where the child at issue has only "remote" Native American heritage).

289 See supra note 5 . Even in the few contexts where the Court has ostensibly extended its affirmative action precedents, it has often in fact applied different gatekeeping standards and declined to apply strict scrutiny across the board to all uses of race. Compare Miller, 515 U.S. at 917 , 920 (holding that strict scrutiny applies to race-based redistricting, but demanding a showing that race was the "predominant factor" in order to trigger review), with Grutter, 539 U.S. at 326 (stating that race need only be a factor in order to trigger strict scrutiny review). See also Ian HaneyLópez, Intentional Blindness, 87 N.Y.U. L. REV. 1779, 1868-71 (2012) (discussing the extension of the colorblindness doctrine to redistricting, and characterizing the Court's contortions to avoid broadly invalidating uses of race in the redistricting context as "comedic").

290 Most notably, the longstanding characterization of government actions that are race targeted but do not individually classify based on race as "race-neutral" has been increasingly problematized by the Court. (This includes, for example, programs like Texas's Ten Percent Plan, race-based school districting to promote integration, and the myriad of other government programs that seek to promote substantive equality goals without formally racially classifying.) See, e.g., Fisher, 133 S. Ct. at 2433 (Ginsburg, J., dissenting) ("Only an ostrich could regard ... supposedly neutral alternatives [to affirmative action, such as Texas's Ten Percent Plan] as race unconscious"); Parents Involved in Cmty. Sch. v. Seattle Sch. Dist. No. 1 (PICS), 551 U.S. 701, 745 (2007) (plurality opinion) (declining to express any opinion "even in dicta" on the constitutional validity of race-intentional government actions); Grutter, 539 U.S. at 340 (questioning 
Justices key to any such doctrinal revolution-including Justices Kennedy, Thomas, and Scalia-have, in ways explicit and implicit, signaled strongly their unwillingness to make such a move. ${ }^{291}$

And yet such nonstrict scrutiny uses of race are becoming increasingly difficult for the Court to simply avoid. As colorblindness's inexorable command has seeped its way deep into legal doctrine and the public consciousness, conservative litigation groups-and the lower courts-have increasingly questioned exemptions that historically have been taken as obvious and benign. ${ }^{292}$ As they do so, the Court will find itself increasingly

whether ten percent plans like Texas's can properly be characterized as "race-neutral"); see also Siegel, Antibalkanization, supra note 12, at 1283 (making a similar observation regarding the increasing problematization of these practices); cf. Lewis v. Ascension Parish Sch. Bd., 662 F.3d 343, 349 (5th Cir. 2011) (questioning, in the aftermath of PICS, whether "benign" race-intentional school redistricting can be exempted from strict scrutiny). But see infra note 291 (discussing the open resistance of several key race conservatives to truly reading the Court's affirmative action precedents as globally requiring strict scrutiny).

291 See, e.g., PICS, 551 U.S. at 787-89, 796-98 (Kennedy, J., concurring) (expressing the normative view that school districts should be able to make use of devices that are intended to increase racial integration but which do not individually classify based on race (such as strategic school site selection, redrawing of attendance zones, etc.), and expressing the view that such approaches should not trigger strict scrutiny); Johnson v. California, 543 U.S. 499, 541 (2005) (Thomas, J., joined by Scalia, J. dissenting) (rejecting, strenuously, the argument that the Court's affirmative action precedents in fact demand the application of strict scrutiny to all uses of race and contending instead that those precedents address only the narrow issue of whether "classifications favoring rather than disfavoring blacks are exempt" from strict scrutiny); Siegel, Antibalkanization, supra note 12, at 1308 (noting the significance of Justice Kennedy's position in PICS); see also supra note 277 and accompanying text (noting that in Adoptive Couple, Justices Scalia and Thomas declined to join even the majority's very soft intimation that the use of racial heritage in adoption might trigger equal protection concerns).

292 For example, the conservative litigation group Pacific Legal Foundation has increasingly called upon the Court to apply strict scrutiny to uses of race that have intended racially ameliorative effects but do not classify racially, a category of race-based practices that the lower courts have traditionally exempted from strict scrutiny review. See, e.g., Brief Amicus Curiae of Pacific Legal Foundation \& Center for Equal Opportunity in Support of Neither Party, Township of Mount Holly, NJ v. Mt. Holly Gardens Citizens in Action, Inc., 134 S. Ct. 636 (2013) (No. 11-1507); Brief for Pacific Legal Foundation as Amicus Curiae Supporting Petitioners, Student Doe $1 \mathrm{v}$. Lower Merion Sch. Dist., 132 S. Ct. 2773 (2012) (No. 11-35); Brief for Pacific Legal Foundation \& Center for Equal Opportunity as Amici Curiae Supporting Petitioners, City of New Haven v. Briscoe, 132 S. Ct. 2741 (2012) (No. 11-1024); Brief for Pacific Legal Foundation et al. as Amici Curiae Supporting Petitioners, Magner v. Gallagher, 132 S. Ct. 1306 (2012) (No. 10-1032); Brief of Pacific Legal Foundation as Amicus Curiae Supporting Respondent, Lewis v. City of Chicago, 560 U.S. 205 (2010) (No. 08-974); Brief for Pacific Legal Foundation as Amicus Curiae Supporting Petitioner, Oakley v. City of Memphis, Tennessee, 557 U.S. 930 (2009) (No. 08-744); Brief for Pacific Legal Foundation et al. as Amicus Curiae Supporting Respondents, Bartlett v. Strickland, 556 U.S. 1 (2009) (No. 07-689).

The lower courts have also in recent years begun to display increased receptiveness to these types of arguments. See, e.g., Lewis v. Ascension Parish Sch. Bd., 662 F.3d 343, 349 (5th Cir. 2011); Fisher v. Univ. of Tex. at Austin, 631 F.3d 213, 242 n.156 (5th Cir. 2011), rev'd on other grounds 133 S. 
faced with a regime in which simply ignoring continued uses of race-and allowing the lower courts to continue to refuse strict scrutiny review-will prove an untenable approach. Thus, we may well be poised at a juncture where the way is uniquely open-and the stakes uniquely high-for a reassessment of the extent to which context should-and does-matter to our constitutional race law jurisprudence.

Such a development-whatever its substantive outcomes-would be an improvement. In an area as divisive and charged as race, it can only breed cynicism and disrespect for the Court to hold out as the fundamental justification for its actions normative and empirical claims that are not true. Nor can such an approach hope to achieve real progress in solving the genuine problems posed by race in our society. In short, without an honest starting point, we cannot hope to have meaningful conversations about the contemporary constitutional significance of race.

\section{CONCLUSION}

As Jed Rubenfeld has observed, it is sometimes only by looking across the sweep of the law that we can understand the Court's true doctrinal and normative commitments. ${ }^{293}$ The contemporary history of race in family law bears this out and demonstrates that even within the relatively narrow span of equal protection doctrine, a nonholistic view can obscure key insights. Thus, it is only by looking across the spread of equal protection doctrineand particularly at the Court's complex role in the history of contemporary race family doctrine-that the very partial nature of the Court's commitment to its colorblindness regime emerges.

This partiality has, or should have, fundamental implications for the Court's race law doctrine. If certain favored uses of race in the law do in fact exist, such uses should be decided not in accordance with the Justices' intuitive and personal views, but instead based on some systematic and transparent means of adjudication. Indeed, it is difficult to imagine a more

Ct. 2411 (2013); Antonelli v. New Jersey, 419 F.3d 267, 273-74 (3d Cir. 2005); cf. Balkin \& Siegel, Principles, supra note 5, at 930-33, 937-43 (describing the process through which consensus can shift as to the applicability of a legal principle, and looking at the example of the collection of racial data and whether it fits within the antidiscrimination principle).

293 Jed Rubenfeld, The Anti-Antidiscrimination Agenda, 111 YALE L.J. 1141, 1144 (2002) (arguing that "[a] line of cases can seem perfectly intelligible when evaluated in its own doctrinal compartment, yet its intelligibility can evaporate altogether when placed side by side with another line of cases," and suggesting that applying such an approach to a number of "the Court's most important new pronouncements in constitutional law" demonstrates that such cases "cannot be taken seriously in their own doctrinal terms, but are better understood as part of an antiantidiscrimination agenda"). 
complete abrogation of the rule of law than the Court's current approach to determining which instantiations of racial decisionmaking receive favored treatment: decisions made in secret, in complete contradiction of the Court's formally articulated legal rule, and without litigant or other stakeholder input. ${ }^{294}$ It is time to bring such concerns out in the open and have a real conversation about which government uses of race should survive.

But how would family law fare under such an explicit regime? Critics claim that contemporary uses of race in family law rest on racial stereotypes and have harmed minority and biracial children by privileging race over all other best interest concerns. ${ }^{295}$ And such critics have observed that there are many facial similarities between contemporary race-based practices in family law and Jim Crow-era practices. ${ }^{296}$ But others have long contended that such practices address very real concerns arising from the identity challenges that minority and biracial children face, and that these practices are necessary to counteract institutional biases against African American caregivers. ${ }^{297}$ And such practices have long had many minority proponents,

294 Cf. Katie R. Eyer, Administrative Adjudication and the Rule of Law, 6o ADMIN L. REV. 647, 654-55 (2008) (describing the consensus elements of the rule of law).

295 See, e.g., KENNEDY, supra note 7, at 403-46 (arguing that race matching harms black and biracial children by depriving them of potential adoptive and foster care homes, as well as causing a host of other related harms); Bartholet, supra note 11, at 1201-26 (suggesting that race-matching policies that aim to place children with adoptive parents of the same race tend to result in a disproportionate delay in or denial of permanent placement for such children); Kim FordeMazrui, Black Identity and Child Placement: The Best Interests of Black and Biracial Children, 92 MiCH. L. REV. 925, 966-67 (1994) (observing that an excessive emphasis on race by courts and placement agencies can cause serious harm to black children awaiting adoption).

296 See, e.g., KENNEDY, supra note 7, at 3-12, 367-73 (describing the historical roots of racematching during the Jim Crow era); Bartholet, supra note 11, at 1175-78 (noting that "near-absolute barriers to transracial adoption" reflected societal segregation and persisted until at least the end of the 1950s); cf. Ward v. Ward, 216 P.2d 755, 755-56 (Wash. 1950) (suggesting that, in the context of a custody dispute, children's best interests could be best achieved when "brought up among their own people"). See generally Grossman, supra note 22, at 333-35 (describing problems and questions posed by interracial adoption in the South in light of its history of hostility toward "interracial social activity").

297 See, e.g., Margaret F. Brinig, The Child's Best Interests: A Neglected Perspective on Interracial Intimacies, 117 HARV. L. REV. 2129, 2141-67 (2004) (book review) (arguing that the best interests of the child should be prioritized, and that such an approach may, in many circumstances, conflict with a colorblind approach to family law); Ruth-Arlene W. Howe, Race Matters in Adoption, 42 FAM. L.Q. 465, 465-69 (2008) (suggesting the "harsh truth" that "African-American children are not well served" when race is not considered); Nat'l Ass'n of Black Soc. Workers, Preserving Families of African Ancestry, http://www.nabsw.org/MServer/PreservingFamilies.aspx (last visited Jan. 24, 2014) (promoting the preservation of families of African ancestry by finding "culturally grounded options" for African American children before considering placing such children "outside of the community"). 
although minority communities are by no means monolithic in their endorsement of contemporary race family law doctrine. ${ }^{298}$

In short, contemporary uses of race in family law lead to no easy answers. But it is time for the constitutional conversation to begin.

298 See, e.g., Preserving Families of African Ancestry, supra note 297; see also Bartholet, supra note 199, at 2352-53 (noting the divided opinions in both black and white communities about the practice of race-matching in adoption). 